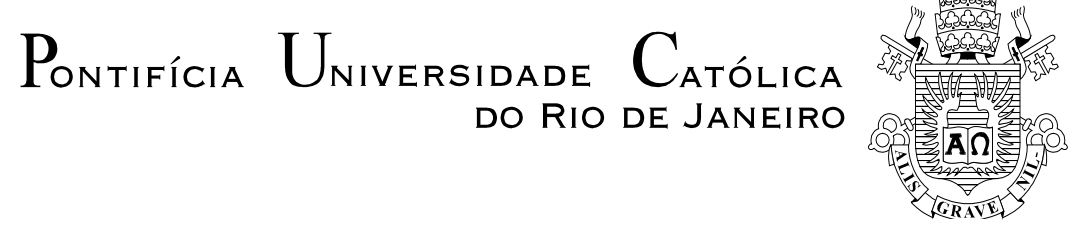

Lúcia Mattoso Monte

\begin{abstract}
Abastecimento de navios na Petrobrás: Modelo de decisão baseado em custos
\end{abstract}

Dissertação de Mestrado

Dissertação apresentada ao Programa de Pós-Graduação em Engenharia de Produção da PUC-Rio como requisito parcial para obtenção do grau de Mestre em Engenharia de Produção.

Orientador: Prof. Rafael Martinelli Pinto

Rio de Janeiro

Agosto de 2018 
Lúcia Mattoso Monte

\title{
Abastecimento de navios na Petrobrás: Modelo de decisão baseado em custos.
}

Dissertação apresentada como requisito parcial para obtenção do grau de Mestre (opção profissional) pelo Programa de Pós-Graduação em Engenharia de Produção da PUC-Rio. Aprovada pela Comissão Examinadora abaixo assinada.

\author{
Prof. Rafael Martinelli Pinto \\ Presidente e Orientador \\ Departamento de Engenharia Industrial - PUC-Rio
}

Prof. Antônio Márcio Tavares Thomé Departamento de Engenharia Industrial - PUC-Rio

Prof. Gustavo Souto dos Santos Diz Petróleo Brasileiro - Rio de Janeiro - Matriz

Prof. Márcio da Silveira Carvalho

Coordenador (a) Setorial do Centro Técnico Científico - PUC-Rio

Rio de Janeiro, 21 de agosto de 2018. 
Todos os direitos reservados. É proibida a reprodução total ou parcial do trabalho sem autorização da autora, do orientador e da universidade.

\section{Lúcia Mattoso Monte}

Graduou-se em Engenharia de produção pela Universidade Federal do Rio de Janeiro (UFRJ) em 2011. Iniciou suas atividades na Petróleo Brasileiro S.A. (Petrobras) em setembro de 2012, na logística de derivados, onde continua até a presente data.

Ficha Catalográfica

Monte, Lúcia Mattoso

Abastecimento de navios na Petrobras: modelo de decisão baseado em custos / Lúcia Mattoso Monte; orientador: Rafael Martinelli Pinto. - 2018.

90 f. : il. color. ; $30 \mathrm{~cm}$

Dissertação (mestrado) - Pontifícia Universidade Católica do Rio de Janeiro, Departamento de Engenharia Industrial, 2018.

Inclui bibliografia

1. Engenharia Industrial - Teses. 2. Cabotagem. 3. Abastecimento. 4. Custos. I. Pinto, Rafael Martinelli. II. Pontifícia Universidade Católica do Rio de Janeiro. Departamento de Engenharia Industrial. III. Título.

CDD: 658.5 


\section{Agradecimentos}

Aos meus pais Adriana e Luiz, que sempre priorizaram minha educação, definitivos responsáveis pelas oportunidades que tive em minha vida, como esse curso.

Ao meu amor Bernardo, que com seu carinho, dedicação e alegria tornou nosso lar o melhor ambiente possível para esses anos.

Aos meus avós, tios e primos, pela compreensão e estímulo nessa jornada.

Aos gestores Cafruni, Steffanello, Lilian e Gil que possibilitaram minha participação no curso e garantiram todo o apoio necessário.

À Petrobras, pela oportunidade e incentivo essenciais para a realização deste mestrado.

Ao meu orientador, Rafael Martinelli, pelo suporte, disponibilidade, confiança e incentivo na condução deste trabalho.

Aos amigos da Petrobras que apoiaram esta dissertação e sem cuja contribuição ela não seria viável: Luiz Gustavo, Igor, Gustavo, Manhães, Magno, Gabriela, Bruno, Giuseppe e tantos outros...

À equipe da Movimentação de Derivados, especialmente aos programadores de Claros dos últimos anos - Rafa, Laslo, Luiz Augusto, Fernanda, Ju e Kenya - sem os quais este trabalho não seria possível.

Aos colegas de turma cujo convívio se revelou o fruto mais especial desse mestrado. 


\section{Resumo}

Monte, Lúcia Mattoso; Pinto, Rafael Martinelli (Orientador). Abastecimento de navios na Petrobras: modelo de decisão baseado em custos. Rio de Janeiro, 2018. 90p. Dissertação de Mestrado Departamento de Engenharia Industrial, Pontifícia Universidade Católica do Rio de Janeiro.

A presente dissertação busca aprimorar o aproveitamento da frota de cabotagem de petróleo e derivados da Petrobras a partir de um novo modelo de custos e de uma ferramenta operacional de decisão de abastecimento das embarcações. Dada a indisponibilidade de estrutura para abastecer em 59 dos 73 pontos operacionais do país, é usual a necessidade de desviar as embarcações da rota de transporte para abastecer. Até o momento, a decisão de onde abastecer os navios da frota não era apoiada por nenhuma ferramenta e havia pouca transparência a respeito dos custos incidentes para os tomadores de decisão. O trabalho consiste em uma pesquisa ação conduzida no contexto de prática das áreas de programação e operação de navios da empresa. A análise inclui uma modelagem de custos, desdobrada em um produto tecnológico englobando um simulador e uma ferramenta de apoio à decisão de quanto e onde abastecer. A dissertação também traz uma proposta de fluxo de decisão padronizado, que aplicado nas rotas realizadas de 2017 demonstra um potencial de economia de 14,8 milhões de reais no ano, sem necessidade de investimentos. Foram analisadas 6.318 escalas de 114 embarcações para a verificação de aderência do fluxo proposto. Apesar da proposta indicar um número maior de operações e maior volume total de abastecimento, a redução de custos é verificada pela eliminação de escalas exclusivas para abastecer. Caso se opte por habilitar o porto de Suape para abastecimentos de navios, é possível estender as economias a pelo menos 4 milhões de reais anuais adicionais.

\section{Palavras-chave}

Cabotagem; Abastecimento; Custos. 


\section{Abstract}

Monte, Lúcia Mattoso; Pinto, Rafael Martinelli (Advisor). Ship refueling at Petrobras: a Cost based Decision Model. Rio de Janeiro, 2018. 90p. Dissertação de Mestrado - Departamento de Engenharia Industrial, Pontifícia Universidade Católica do Rio de Janeiro.

The main goal of this dissertation is to improve the usage of Petrobras' crude oil and oil products short sea fleet through a new cost model and an operation decision tool regarding its refueling activities. Currently, it is common practice to deviate the ships from their transportation route to refuel, given the lack of refueling structure in 59 of the 73 ports and platforms in which the short sea fleet operates. Until this moment, the refueling decision wasn’t supported by any tool and there was little transparency regarding the cost impact to the decision makers. This action research is conducted within the context of practice of the ship operations and ship scheduling areas. This works' contributions include a refueling cost model, that is later unfolded in a technological product that includes a Decision Support Tool that helps to decide when and which Fuel Oil quantity to refuel. The dissertation also designs a standardized decision flow, that results in a 14,8 million Reais yearly saving potential when applied to the 2017 routes, no investment needed. To verify the adhesion of the proposed flow, 6.318 port calls made by 114 vessels were analysed. Despite the larger number of refueling operations and total fuel quantity proposed, the cost reduction is verified due to the elimination of the port calls made exclusively for refueling. If the option is made to enable refueling activity in the port of Suape, it is possible to further increase the yearly savings in at least 4 million Reais.

\section{Keywords}

Short sea; Refueling; Costs. 


\section{Sumário}

1 Introdução 12

2 Revisão da literatura $\quad 18$

2.1. Gestão do consumo de combustível $\quad 18$

2.2. Fornecimento de bunker 21

2.3. Custos de transporte marítimo 22

3 Metodologia $\quad 26$

$\begin{array}{ll}\text { 3.1. Unidade de análise } & 27\end{array}$

3.2. Fontes de informação e métodos de coleta de dados 28

3.3. Métodos de análise $\quad 30$

3.4. Modelagem de custos 32

3.4.1. Custos de suprimento de bunker - Petrobras enquanto fornecedora 32

3.4.2. Custos de transporte marítimo - Frota Petrobras enquanto cliente 35

3.4.3. Incidência de custos por situação de abastecimento 36

3.4.4. Custo realizado de 2017

3.5. Desenvolvimento de fluxo de decisão 41

3.6. Validação dos resultados 43

4 Aplicação e Resultados

4.1. Contexto da pesquisa ação 45

4.1.1. Abastecimento da frota de cabotagem Petrobras 50

4.1.2. Disponibilidade de abastecimento por terminal 53

4.1.3. Suprimento de bunker 56

4.1.4. Pontos potenciais para abastecimento 58

4.2. Modelo de custos $\quad 61$

4.3. Ferramenta de apoio à decisão 64

4.4. Custo realizado de $2017 \quad 67$

4.5. Fluxo de decisão de abastecimento $\quad 71$

4.6. Avaliação de novos pontos de abastecimento 76

5 Conclusão $\quad 82$

5.1. Trabalhos futuros $\quad 84$

6 Referências bibliográficas $\quad 85$

Apêndice 1 - Detalhamento de Pontos Operacionais 88

Anexo 1 - Tarifas TRANSPETRO de transporte em dutos curtos 90 


\section{Lista de figuras}

Figura 1 - Duração de escalas exclusiva para abastecer em 2017 .......................... 15

Figura 2 - Modelo de pesquisa ação .................................................................... 26

Figura 3 - Processo de Pedido de Abastecimento..................................................... 27

Figura 4 - Exemplos de rotas de cabotagem de bunker para o porto de

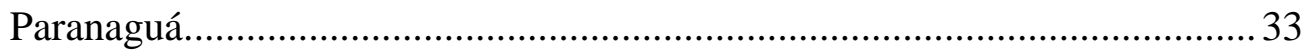

Figura 5 - Píer de Barcaças e Parque de Tanques na Ilha d'Água ......................... 45

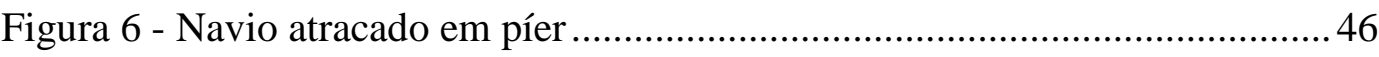

Figura 7 - Barcaça amarrada em navio ............................................................... 46

Figura 8 - Conexão de mangote entre barcaça e navio.......................................... 47

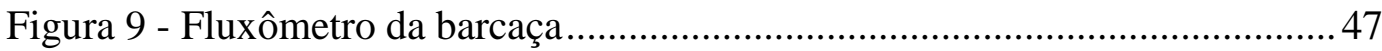

Figura 10 - Navio, barcaça, rebocador e barco de apoio durante operação de

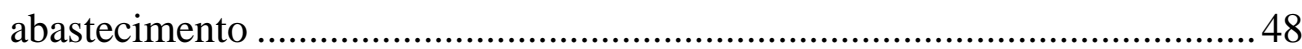

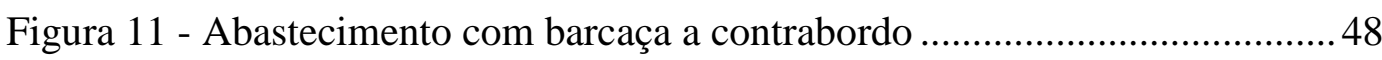

Figura 12 - Navios fundeados na Baía de Guanabara ........................................... 49

Figura 13 - Possibilidades de abastecimento e posição do navio correspondente. 50

Figura 14 - Manobra adicional para fundeio ........................................................ 51

Figura 15 - Inclusão de porto para abastecimento na rota.......................................52

Figura 16 - Inclusão de porto com desvio de rota para abastecimento...................53

Figura 17 - Portos com abastecimento por duto disponível em 2017 ....................54

Figura 18 - Exemplos de rotas de cabotagem de bunker ....................................... 57

Figura 19 - Exemplo de cálculo de custo de cabotagem de bunker .......................61

Figura 20 - Exemplo de cálculo de custo médio de cabotagem por destino .........6 61

Figura 21 - Custos de Abastecimento na situação "Fundeio Exclusivo" ...............62

Figura 22 - Custos de Movimentação de Produto por Porto ...................................63

Figura 23 - Custos Portuários por Terminal .......................................................63

Figura 24 - Exemplo de abastecimentos entre Guamaré e Rio de Janeiro ..............64

Figura 25 - Custos de abastecimento em Rio de Janeiro na rota Guamaré - Rio

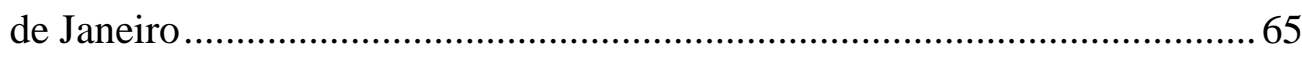

Figura 26 - Custos de abastecimento em Tubarão na rota Guamaré - Rio de

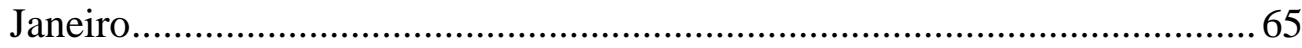

Figura 27 - Situações de abastecimento elencadas por custo ................................66 
Figura 28 - Número de escalas por atividade realizada.......................................68

Figura 29 - Diagrama de escalas por tipo de atividade..........................................6 68

Figura 30 - Custos de abastecimento de 2017 por item..........................................69

Figura 31 - Operações de abastecimento mais onerosas do Cenário Realizado.... 69

Figura 32 - Número de operações de abastecimento por faixa de custo ................ 70

Figura 33 - Fluxo de decisão de abastecimento proposto...................................... 73

Figura 34 - Reclassificação do porto de Belém ..................................................... 75

Figura 35 - Custos de abastecimento por cenário ................................................... 75

Figura 36 - Operações mais onerosas do Cenário Proposto ................................... 76

Figura 37 - Custo total de abastecimentos com inclusão do porto Suape ............. 79

Figura 38 - Custo total de abastecimentos com inclusão do porto São Luís .......... 79

Figura 39 - Custo total de abastecimentos com inclusão dos portos Suape e

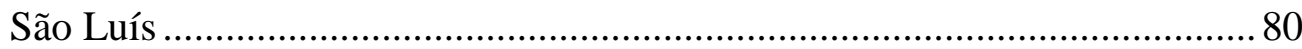




\section{Lista de tabelas}

Tabela 1 - Impactos por modal de abastecimento ............................................. 22

Tabela 2 - Itens de custos abordados na revisão da literatura ............................... 25

Tabela 3 - Disponibilidade de abastecimento por tipo de ponto operacional........ 29

Tabela 4 - Etapas da Pesquisa Ação .................................................................... 30

Tabela 5 - Custos de suprimento de bunker aplicáveis por porto.......................... 35

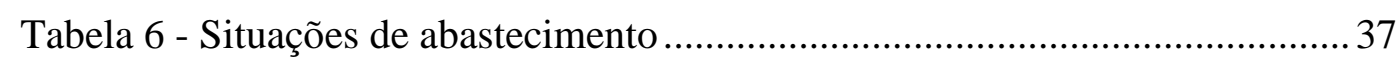

Tabela 7 - Custos aplicáveis por situação de abastecimento ................................ 38

Tabela 8 - Situações de abastecimento por porto ............................................... 40

Tabela 9 - Portos com abastecimento disponível em 2017 ................................... 54

Tabela 10 - Disponibilidade de Abastecimento por Porto..................................... 56

Tabela 11 - Origem do bunker por porto .......................................................... 58

Tabela 12 - Viabilidade de abastecimento por terminal .......................................6 60

Tabela 13 - Pontos operacionais potenciais para abastecimento ......................... 77 


\section{Lista de Siglas}

ANP Agência Nacional do Petróleo, Gás Natural e Biocombustíveis

ANTAQ Agência Nacional de Transportes Aquaviários

COA Contract of Affreightment, modalidade de contratação de navios remunerada por quantidade movimentada

FUNAPOL Fundo para Aparelhamento e Operacionalização das AtividadesFim da Polícia Federal

GLP Gás Liquefeito de Petróleo

GNL Gás Natural Liquefeito

LUBNOR Refinaria Lubrificantes e Derivados do Nordeste - Fortaleza, Ceará

MF Marine Fuel, óleo combustível marítimo

MGO Marine Gasoil, óleo diesel marítimo

OCCMB Óleo combustível com controle de metais e baixo enxofre

REFAP Refinaria Alberto Pasqualini - Canoas, Rio Grande do Sul

REGAP Refinaria Gabriel Passos - Betim, Minas Gerais

REPAR Refinaria Presidente Getúlio Vargas - Araucária, Paraná

RLAM Refinaria Landulpho Alves - São Francisco do Conde, Bahia

RNEST Refinaria Abreu e Lima - Ipojuca, Pernambuco

SUEZMAX Classe de navio com porte de 120.000 a 170.000 toneladas

TCP Time Charter Party, modalidade de contratação de navios por tempo determinado

TUF Taxa de Utilização de Faróis

VCP Voyage Charter Party, modalidade de contratação de navios por viagem 


\section{1 \\ Introdução}

A navegação de cabotagem foi responsável pela movimentação de 52,7 milhões de toneladas de carga no Brasil no segundo trimestre de 2017 (Boletim Informativo Aquaviário ANTAQ $2^{\circ}$ Trimestre 2017). Ainda segundo a ANTAQ, a movimentação de petróleo correspondeu a 61\% desse volume. O transporte marítimo é essencial para garantir a continuidade da produção de petróleo nas plataformas, o processamento de petróleo nas refinarias e a distribuição de seus derivados no mercado nacional, podendo um atraso de embarcação ocasionar falhas de suprimento incontornáveis. Dessa forma, é importante para a população e as indústrias do país que a cabotagem de petróleo e derivados ocorra com o melhor aproveitamento da frota possível.

A Petrobras é uma empresa integrada de energia com atuação em todo território brasileiro. Sua frota de cabotagem é essencialmente contratada em modalidade TCP (Time Charter Party), modalidade de afretamento em que a embarcação é contratada por tempo e remunerada por um aluguel diário. Nessa modalidade, os custos e a decisão do abastecimento de combustível dos navios são de responsabilidade do afretador (Wang et al., 2017). Sendo uma empresa verticalizada, a Petrobras é também fornecedora de combustível marítimo (óleo combustível marítimo e diesel marítimo) para suas próprias embarcações e para terceiros no país.

A atividade de cabotagem da empresa engloba transporte de petróleo cru, gás liquefeito de petróleo (GLP) e derivados (classificados em claros, escuros e especiais) por 73 pontos operacionais no país, dos quais 41 plataformas, 8 monoboias e 24 portos. Em nenhuma das plataformas ou monoboias é possível realizar abastecimento de navios, inviabilidade característica da própria estrutura operacional. Dos 24 portos utilizados na cabotagem de petróleo e derivados, apenas 14 oferecem abastecimento de navios.

Caso uma embarcação seja programada para operar sucessivamente em pontos operacionais que não possuam estrutura para abastecimento, pode ser 
necessário desviar o navio de sua rota para garantir sua autonomia em detrimento da otimização do transporte de carga.

Segundo Zockaie et al. (2016), esses desvios podem ser tratados como perda morta ao sistema dado o tempo perdido, além do consumo adicional de combustível envolvido no próprio desvio. Em se tratando de bunker (combustível marítimo, um subproduto do refino de petróleo), esse consumo aumenta a emissão de gases poluentes e gases de efeito estufa (Wang et al., 2013).

Hoje, a decisão de onde abastecer os navios da frota respeita alguns direcionadores gerais, porém não segue um fluxo estruturado.

O objetivo da dissertação é prover uma solução que reduza os impactos de custos operacionais causados pelas operações de abastecimento de navios da frota de cabotagem.

Os objetivos específicos são:

1. Desenvolver um modelo de custos de abastecimento de navios para a realidade de uma empresa integrada de energia.

2. Verificar potenciais economias a partir da estruturação do processo de tomada de decisão de abastecimento.

3. Verificar potenciais economias a partir da seleção de novos pontos para abastecer.

Para transportar petróleo, gás e derivados pelo país, a Petrobras operou 147 navios afretados em modalidade TCP ao longo de 2017, incluindo contratos encerrados e iniciados ao longo do ano. Os combustíveis utilizados pelos motores dessas embarcações são comumente chamados de bunker.

As embarcações de médio e grande porte consomem em seu motor principal o óleo combustível marítimo, também tratado como marine fuel ou MF, enquanto as embarcações de pequeno porte são movidas a óleo diesel marítimo também chamado de marine gasoil ou MGO (Cristo, 2014). Ainda segundo Cristo (2014), o MGO também é utilizado para geração de energia elétrica no motor auxiliar das embarcações, independente do porte.

Em 2017 a Petrobras entregou 4,3 milhões de toneladas de bunker no Brasil, sendo 3,8 de MF e 0,5 de MGO. Das entregas de MF, apenas 7,8\% corresponderam a abastecimento da frota TCP da Petrobras, para que realizassem viagens de cabotagem, importação e exportação de petróleo, gás e derivados. As 3,5 milhões de toneladas restantes corresponderam à venda de MF no país. 
Na cabotagem de petróleo, gás e derivados da Petrobras não são utilizadas embarcações movidas a MGO no motor principal. A necessidade de reposição de MGO nas embarcações ocorre com frequência menor que a reposição de MF, e usualmente é feita na mesma ocasião de alguma reposição de MF.

Não há hoje na Petrobras um fluxo estruturado para a tomada de decisão de abastecimento da frota TCP. Frequentemente, a decisão de programação dos navios é revista em função da autonomia de navegação das embarcações para o combustível disponível. Com a indisponibilidade de estrutura de abastecimento em 41\% dos portos, as rotas de 2017 foram impactadas pela necessidade de bunker, gerando escalas realizadas exclusivamente para abastecer. Essas escalas podem gerar atrasos na rota de transporte e perda de janela de atracação, obrigando o navio a aguardar liberação de píer e resultando em tempo total de viagem ainda maior. Além disso, para um navio afretado em TCP, o tempo dessa escala representa um custo de aluguel sem benefício associado, dado que o percurso não gerou valor para o transporte de carga.

Isso reforça a importância de se buscar soluções que permitam reduzir a frequência da necessidade de mudança de rota para abastecimento, como o modelo de Besbes e Savin (2009), que trata a decisão de abastecimento de forma conjunta à roteirização. A complexidade da cabotagem de petróleo, gás e derivados, todavia, sugere que se busque uma solução genérica para a eliminação de escalas exclusivas para abastecimentos de navio, seja por estruturação do processo de tomada de decisão ou por inclusão de novos pontos de abastecimento. Desta forma, as decisões de roteirização poderão se basear puramente nas flutuações de oferta e demanda dos produtos transportados e não terão seu gargalo na autonomia das embarcações utilizadas.

É possível encontrar na literatura estudos referentes a decisões de abastecimento tanto em termos de contratos com fornecedores de bunker (Ghosh et al., 2015 e Pedrielli et al., 2015) quanto roteirização incluindo custos de abastecimento (Besbes e Savin, 2009). Apesar de muitos estudos abordarem tópicos divergentes desta dissertação, como velocidade de navegação (Aydin et al., 2017, Wang e Meng, 2015, Yao et al., 2012 e Sheng et al., 2014) e roteirização (Besbes e Savin, 2009), a preocupação da academia com redução do consumo de combustível fóssil é frequentemente refletida e compatível com o tema da dissertação. 
Não foi encontrado, entretanto, estudo para empresa verticalizada que produza e forneça o próprio combustível marítimo, com foco no aproveitamento da frota. Há uma intenção similar de aproveitamento da frota no caso de seleção de novos pontos de abastecimento para veículos rodoviários de combustível alternativo de Zockaie et al. (2016). Todavia, no transporte marítimo, o abastecimento conciliado com operações de carga e descarga traz ganhos logísticos, manifestados na própria preferência de transportadoras comerciais $(\mathrm{Hu}$, 2005 apud Wang et al., 2014). No caso da Petrobras, a parada de uma embarcação para abastecimento em terminal sem operação de carga e descarga representa na maioria dos casos uma parada de pelo menos um dia, conforme ilustrado na Figura 1. Esse tempo reflete pelo menos o custo de uma diária de aluguel de embarcação, da ordem das dezenas de milhares de dólares. Assim, a inclusão de um ponto de abastecimento em que não há carga ou descarga de produto ao longo do caminho entre origem e destino não apresenta tanto valor para o modal marítimo quanto para o rodoviário.

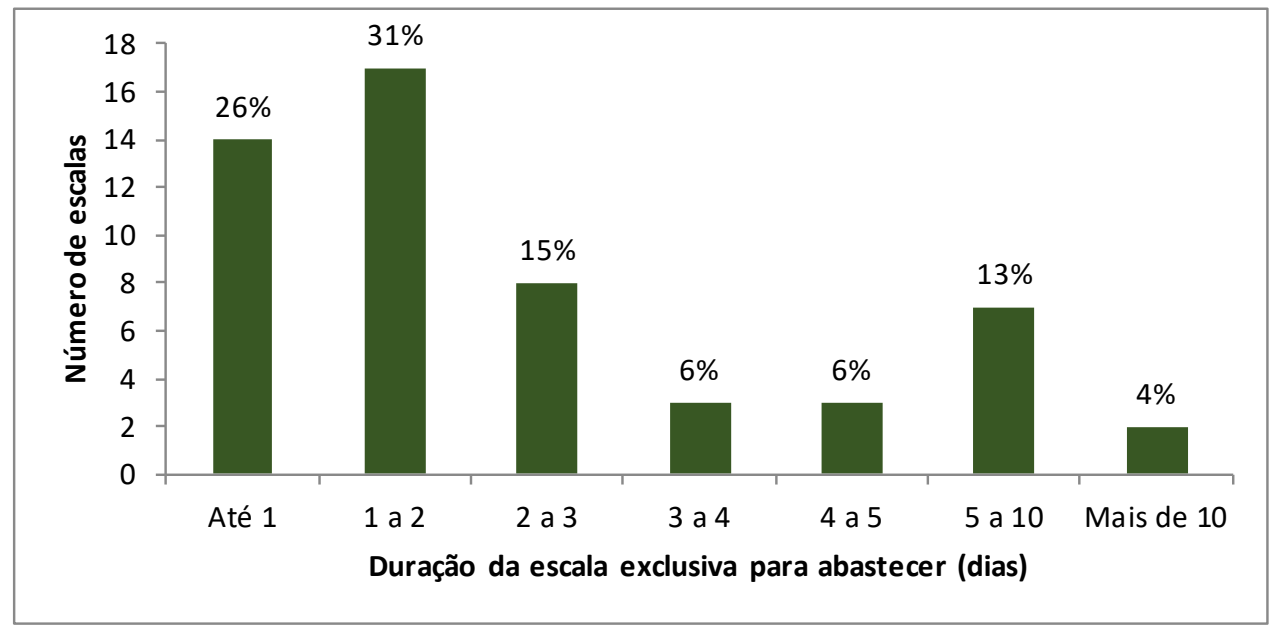

Figura 1 - Duração de escalas exclusiva para abastecer em 2017.

Fonte: A autora.

Dessa forma, a dissertação traz as seguintes contribuições:

1. Modelo de custos de abastecimento de navios para uma empresa verticalizada de energia;

2. Ferramenta de apoio à decisão de abastecimento;

3. Proposta de fluxo de decisão padronizado para quando e quanto abastecer; 
4. Avaliação de economias na inclusão de novos pontos de abastecimento.

Por se tratar de trabalho conduzido por membro da equipe de programação de navios, optou-se por uma metodologia de pesquisa ação. Segundo Huang (2010), na pesquisa ação os pesquisadores trabalham com praticantes em um contexto de prática.

A pesquisa não comparará como os novos pontos de abastecimento podem afetar o mercado de venda de bunker para terceiros, uma vez que, dada a existência da estrutura, a área comercial pode optar por usufruir dela ou não para a venda. A pesquisa busca identificar aqueles pontos em que a disponibilidade de abastecimento para a frota TCP já justifica por si só o investimento em infraestrutura.

Não serão estudados os abastecimentos de MGO e toda menção a bunker poderá ser interpretada diretamente como Marine Fuel (MF). Não serão avaliados os abastecimentos para viagens de exportação e importação, devido a suas decisões serem influenciadas pelos requisitos de qualidade de combustível exigidos para navegação em áreas de controle de emissão de poluentes (Emission Control Areas ou ECA). Ademais, no caso de navios afretados na modalidade VCP (viagens spot utilizadas no Longo Curso), a decisão e os custos do abastecimento não são da Petrobras, mas do fretador, sendo as entregas de bunker a essas embarcações tratadas como vendas. Dessa forma, o escopo se restringirá aos abastecimentos da frota TCP alocada em rotas de cabotagem.

Vale ressaltar que, restringindo o escopo às rotas de cabotagem, a frota TCP de gás natural liquefeito (GNL) foi removida da análise, uma vez que seus navios apenas realizam viagens internacionais. Também foram desconsiderados navios que, em função de suas programações, passam mais tempo parados do que navegando. São aqueles que funcionam como tancagem flutuante de água de formação e aqueles que fornecem diesel marítimo para as plataformas. Esses dados foram expurgados pois o perfil de suas atividades faz com que os navios saiam de suas rotas buscando outros ressuprimentos que não o de óleo combustível marítimo, como de alimentação, água potável, MGO etc., e os dados poderiam ser equivocados por escalas para abastecimento.

Dentre os pontos operacionais de carga e descarga de petróleo e derivados, serão desconsiderados como potenciais pontos de abastecimento aqueles cuja 
estrutura inviabiliza a realização de investimentos para abastecimentos, como plataformas e monoboias. Esses pontos serão detalhados no Capítulo 4.

Ao longo da dissertação, serão respondidas as seguintes perguntas:

1. Como são feitos os abastecimentos de navios da frota de cabotagem de Petróleo e Derivados?

2. Como modelar os custos envolvidos em uma operação de abastecimento para uma empresa verticalizada de energia?

3. É possível reduzir os custos de abastecimento a partir da estruturação da decisão de onde e quanto abastecer? Qual a economia esperada?

4. Como selecionar potenciais pontos de abastecimento que tragam redução nos custos operacionais atuais?

5. Qual a economia esperada com o acréscimo dos pontos de abastecimento considerando as rotas realizadas no último ano?

A dissertação é composta de cinco capítulos: Introdução, Revisão da literatura, Metodologia, Aplicação e resultados e Conclusão.

A revisão da literatura traz o ponto de vista da academia e da empresa estudada quanto à gestão do consumo de combustível, fornecimento de bunker e custos de transporte marítimo.

Em seguida, é exposta a metodologia de pesquisa, com detalhamentos sobre a condução da pesquisa ação, aprofundando sobre o levantamento de dados, a modelagem de custos e o desenvolvimento de decisão padronizado.

O Capítulo 4 traz os resultados observados pela aplicação dos métodos descritos, tanto quanto aos custos atuais de abastecimento de navios, quanto da simulação do fluxo de decisão proposto e da inclusão de novos pontos de abastecimento.

Por fim, a conclusão retoma as perguntas de pesquisa, avalia o cumprimento do objetivo da dissertação e lista oportunidades para trabalhos futuros. 


\section{Revisão da literatura}

Atualmente a academia trata separadamente o fornecimento de combustível para embarcações de terceiros (Drake, 2003 e Cristo, 2014) das decisões de abastecimento de navios tomadas pelos gestores da frota (Aydin et al., 2017, Wang et al., 2013, Ghosh et al., 2015 e Besbes e Savin, 2009). Não foi encontrado, entretanto, estudo que preveja o fornecimento interno de bunker para frota de cabotagem de uma empresa verticalizada de petróleo.

Assim, este capítulo aborda também separadamente os estudos que se referem à gestão do consumo de combustível daqueles referentes a fornecimento de bunker. A revisão inclui estudos de custos de transporte marítimo. Estes são tratados na literatura essencialmente para estudos de roteirização, mas são aplicáveis aos desvios de rota observados na frota da Petrobras. Foram buscados documentos e estudos internos que transparecessem o ponto de vista da empresa para cada um dos tópicos abordados neste capítulo.

\section{1}

\section{Gestão do consumo de combustível}

O óleo combustível marítimo (MF) é produzido com matéria prima semelhante aos óleos combustíveis industriais: as frações mais pesadas do petróleo, como o resíduo de vácuo da destilação (Farah, 2015). Ainda segundo Farah (2015), os requisitos de qualidade do MF são distintos dos óleos industriais devido a seu emprego em motores a combustão interna, diferente da queima de óleo combustível em fornos e caldeiras.

Segundo Prada Junior (2007), o mercado de óleo bunker cresce de acordo com o comércio marítimo mundial, enquanto o óleo combustível industrial vem sendo substituído pelo gás natural em função de restrições ambientais, apresentando assim uma redução na demanda.

A preocupação com a gestão do consumo de bunker é perceptível na literatura, com estudos conciliando ajustes nas velocidades das embarcações à 
decisão de quando e onde abastecer o navio (Sheng et al., 2014, Aydin et al., 2017 e Wang et al., 2013) e estudos sobre contratação de abastecimento adequada (Ghosh et al., 2015 e Pedrielli et al., 2015).

Besbes e Savin (2009) propõem um modelo de maximização de lucro de uma embarcação considerando a roteirização e decisão de abastecimento de forma conjunta de acordo com a variação de preço do bunker. Apesar de identificar o preço do bunker como o principal fator chave para seleção de porto de abastecimento em seu estudo de caso, Wang et al. (2014) coloca que a escolha de abastecimento não segue regras fixas e as decisões são frequentemente tomadas em decorrência de circunstâncias operacionais imprevistas. Ainda segundo Wang et al. (2014), vantagem geográfica, capacidade de abastecimento e tempo de espera são fatores relevantes nessas decisões.

A restrição de capacidade de abastecimento não é tratada apenas no âmbito do transporte marítimo. Darnell et al. (1977) criaram um modelo de gestão e alocação de combustível para aeronaves considerando o preço do combustível em cada aeroporto, a disponibilidade de combustível de cada estação e outras restrições referentes à tancagem e segurança da aeronave. Aeronaves e navios são modais semelhantes em diversos aspectos, como grande investimento de capital traduzido em custos diários elevados, existência de taxas portuárias e alta dependência em condições temporais e tecnológicas (Christiansen et al., 2007). Ainda segundo Christiansen et al. (2007), a principal diferença de programação entre os modais consiste na rota contínua dos navios, que não possui colchões de ociosidade planejada capazes de absorver atrasos, como nas aeronaves.

O modelo de Zockaie et al. (2016), que propõe localizações de estações de abastecimento para veículos rodoviários de combustível alternativo minimizando seus desvios de rota, também considera um limite superior de capacidade nessas estações. Segundo os autores, o tempo adicional de viagem por desvio de rota para abastecimento não é tão preocupante para usuários de veículos rodoviários convencionais em países desenvolvidos, que contam com uma rede densa de postos de gasolina e diesel.

Para caminhões convencionais, softwares utilizados focam em minimizar custos de abastecimento, sugerindo uso de rotas mais extensas para alcançar postos que dispõem de combustível mais barato (Suzuki et al., 2013). Ainda segundo Suzuki et al. (2013), o uso dessas rotas pode resultar em maior tempo de 
trânsito e aumentar o risco de violação de janelas de tempo de entrega. Essa violação de janelas de tempo é análoga ao transporte marítimo, em que muitas vezes a atracação só é possível em determinadas condições de maré, luz e disponibilidade de berço. As janelas de atracação dos portos são, em conjunto com o tempo de trânsito entre portos, os principais fatores de decisão de velocidade de navegação (Aydin et al., 2017).

Zhen et al. (2017) desenvolvem um modelo de programação dinâmica para navios de contêiner com rota fixa (liner) para decisão de onde e quanto abastecer em função de preço e consumo de bunker variáveis. As rotas estudadas envolvem um consumo total superior à capacidade dos tanques de bunker das embarcações, tornando inviável completar toda a navegação sem abastecimento ao longo dos portos operados. Apesar da rota fixa, os autores consideram que o consumo de bunker é afetado não só pela velocidade de navegação, mas também pelo peso da carga a bordo e condições de tempo e mar.

A função objetivo do modelo de Zhen et al. (2017) consiste em minimizar o custo esperado total do Porto 1 ao último porto considerando a quantidade de bunker disponível nesse primeiro porto. Dentre as restrições, destacam-se aquelas que estabelecem que:

1. A quantidade de combustível disponível no navio na chegada no porto i+1 é igual à:

a. quantidade de combustível disponível no navio na chegada no porto i

b. mais a quantidade abastecida em $\mathrm{i}$

c. menos o consumo na perna i (do porto i ao porto $\mathrm{i}+1$ ).

2. Se a quantidade de bunker disponível na chegada em i é inferior à quantidade estocástica esperada para chegar de i a i+1, o navio abastece no mínimo a quantidade correspondente ao consumo esperado entre i e $\mathrm{i}+1$.

3. A soma entre a quantidade de bunker disponível na chegada em i e a quantidade abastecida em i não pode exceder a capacidade do tanque de bunker da embarcação.

Apesar da situação estudada divergir consideravelmente da realidade da cabotagem de petróleo e derivados - em que a rota dos navios é revisada ao longo da própria viagem e o bunker fornecido é produzido pela própria companhia, as 
restrições do modelo são aplicáveis, se ajustadas, às decisões de abastecimento da frota.

A preocupação com redução de consumo de bunker é perceptível também nos processos internos da companhia. A Petrobras premiou internamente um estudo que reviu a necessidade de aquecimento dos tanques de navios de óleo combustível de acordo com as especificações do produto a fim de poupar o gasto energético dessas embarcações (Carmo, 2014).

\section{2}

\section{Fornecimento de bunker}

Drake (2003) realiza uma análise custo benefício entre fornecimento de bunker via duto e via barcaça na base naval de Pearl Harbor no Havaí. Inicialmente, o estudo descreve o processo de abastecimento, que se inicia com a requisição pelo cliente. O cliente especifica o tipo e quantidade de combustível necessários, bem como instruções operacionais específicas à embarcação. Na sequência, é determinado como fornecer o combustível, em função do tráfego portuário, prioridade de manobras, disponibilidade de ativos e especificações do cliente. A equipe de operações portuárias define a prioridade dos abastecimentos de acordo com disponibilidade dos ativos e urgência. Após definir como será realizado o abastecimento, são alocados os recursos necessários, como rebocadores, operadores, equipamentos e infraestrutura. Na sequência são tocados os trâmites operacionais, havendo comunicação entre engenheiros e equipe de suprimento para ajustes como conectores, adaptadores e obrigações administrativas e de pagamentos.

Em ambos modais (duto e barcaça) é necessário um barco de apoio para cercamento das embarcações de forma a conter eventuais derramamentos de combustível. Caso o abastecimento seja feito por barcaça, é necessário carregar a barcaça com combustível proveniente do duto, e posteriormente abastecer o navio com o produto da barcaça. Isso representa um duplo manuseio do combustível quando comparado à operação no píer.

Drake (2003) cita como diferenças relevantes entre os modais a vazão e a capacidade de abastecimento, mais restritas na barcaça que nos abastecimentos 
por duto, a flexibilidade da barcaça e os riscos ambientais. A Tabela 1 detalha todas as diferenças observadas.

Tabela 1 - Impactos por modal de abastecimento.

\begin{tabular}{lll}
\hline \multicolumn{1}{c}{ Impactos } & \multicolumn{1}{c}{ Duto } & \multicolumn{1}{c}{ Barcaça } \\
\hline Tempo & Manuseio único & Duplo manuseio \\
Derramamento de combustível & Menor probabilidade & Dobro da probabilidade \\
Custos de renovação & A cada 10 anos & A cada 4 anos \\
Barreira de contenção & Uma vez por operação & Duas vezes por operação \\
Serviço ao cliente & Mais rápido, & Mais lento, \\
& Sem rebocador, & Rebocador necessário, \\
Prontificação & Maior capacidade & Capacidade limitada \\
Classes de navio servidas & Restrito ao número de berços por píer & Restrito ao número de barcaças disponíveis \\
& Todas & Não atende grandes portes (Porta Aviões,
\end{tabular}

Fonte: Adaptado de Drake (2003).

Segundo Cristo (2014), grande parte dos abastecimentos no Brasil são via barcaça, realizados por prestadoras de serviço de transporte e entrega de bunker contratadas pela Petrobras. O estudo desenvolveu uma metodologia para avaliação contínua da percepção dos clientes dos abastecimentos de bunker quanto aos serviços prestados pelas embarcações abastecedoras contratadas pela Petrobras. Segundo o autor, os abastecimentos por barcaça no país se iniciam nos terminais da Transpetro com o carregamento do produto nas embarcações. Após a carga do bunker, as barcaças são deslocadas e atracadas junto aos navios clientes e é feito o abastecimento, com a entrega de combustível para o cliente.

A próxima seção trata de custos de transporte marítimo, a fim de avaliar o impacto financeiro de uma operação de abastecimento para a frota a ser abastecida.

\section{3}

\section{Custos de transporte marítimo}

Fruto de um investimento de milhões de dólares, um navio geralmente representa um custo operacional diário da ordem das dezenas de milhares de dólares. Desta forma, o planejamento da frota e de suas operações tem o potencial de melhorar seu desempenho econômico e, consequentemente, reduzir custos de frete (Christiansen et al., 2007).

Na Petrobras, a importância da gestão da frota está em linha com os desdobramentos do Plano de Negócios e Gestão 2018-2022, como parte da ação 
complementar de Redução Adicional de Dispêndios (custos operacionais e investimentos), (Petrobras, 2018).

Segundo Christiansen et al. (2007), navios operam em portos para carregar e descarregar produtos, abastecer combustível, água potável, suprimentos e descartar resíduos. Portos cobram taxas por seus serviços e esses custos variam de acordo com o tamanho da embarcação. Portos também impõem limitações físicas aos navios que podem operar neles, como calado, comprimento e porte bruto.

Ainda segundo Christiansen et al. (2007), o tempo passado em portos é um mal necessário para a carga e descarga dos produtos transportados, uma vez que navios são produtivos e remunerados ao navegar.

Os autores também enumeram os três principais modos de operação comercial de navios:

1. As operações do tipo Liner funcionam de forma semelhante a uma linha de ônibus, respeitando programação e itinerário publicados. Esse tipo de operação transporta usualmente contêineres e carga geral.

2. Já os navios de operação Tramp, tipicamente usada para navios tanque ou de granel sólido, buscam cargas disponíveis de forma análoga a um táxi. Usualmente esses operadores comparam suas previsões para o mercado spot (contratos por viagem ou VCP) com contratos do tipo COA (Contract of Affreightment), em que uma quantidade de carga acordada deve ser transportada dentro de um espaço de tempo e a remuneração é por unidade de carga.

3. Por fim, a operação Industrial ocorre quando os donos da carga controlam a frota que a transporta, seja uma frota própria ou afretada por tempo (TCP). É uma operação comum na comercialização de grandes volumes em companhias verticalizadas de granel líquido ou sólido, como petróleo, produtos químicos e minério. Operadores industriais buscam minimizar o custo para transportar a totalidade de suas cargas.

Em Christiansen et al. (2007) também são apresentadas modelagens matemáticas para problemas típicos de operações industriais. Em um problema de dimensionamento da frota com cargas cheias, faixas de atendimento conhecidas, tempos de operação conhecidos e atendimento à demanda total obrigatório, o 
custo das pernas carregadas é considerado constante e desconsiderado. Assim, o objetivo se torna minimizar o custo total das pernas em lastro. Esse objetivo é análogo à intenção de Zockaie et al. (2016) de minimizar os desvios de rota para abastecimento dos veículos de combustível alternativo, dado que esses desvios podem ser tratados como perda morta ao sistema, de forma similar à navegação em lastro.

Em um contrato TCP, além de pagar um aluguel diário ao armador, o afretador da embarcação arca com os custos portuários e de combustível (Wang et al., 2017). Para os contratos VCP, está previsto um aspecto da lei marítima da Inglaterra chamado demurrage (sobreestadia), que é definido como uma quantia acordada entre as partes a ser paga ao armador em respeito a um atraso da embarcação além do período de tempo acordado para carga ou descarga, atraso esse que não seja de responsabilidade do armador (Scofield, 2011).

Moreira (2008) cita os quatro grupos contábeis utilizados pela Petrobras para as despesas associadas ao transporte marítimo. São eles:

1. Transporte Operacional: referente aos fretes (navios VCP) e aluguéis (navios TCP);

2. Materiais, Combustíveis e Lubrificantes: referente aos gastos de reposição dos itens mencionados;

3. Serviços Gerais: Serviços de portos (ex.: agente, despachante, prático, lancha, rebocador etc.)

4. Serviços Públicos, Aluguéis e Encargos Gerais: para encargos, taxas e sobreestadia de VCPs

Ao contabilizar os custos de transporte marítimo referentes ao ano de 2007, Moreira (2008) reorganizou os grupos acima em cinco categorias:

1. Aluguel (incluindo fretes de VCPs),

2. Combustível (apenas para TCPs),

3. Despesa Portuária,

4. Sobreestadia (apenas para VCPs) e

5. Outros, uma vez que os demais custos eram pouco significativos para serem considerados separadamente.

Segundo Diz et al. (2014), os custos operacionais a serem considerados em uma rota marítima são:

- diária do navio (para TCP), 
- custo de combustível (TCP),

- demurrage (VCP),

- taxas portuárias (ambos) e

- frete (VCP).

Diz et al. (2014) também reforçam a importância na roteirização de se calcular o custo da reposição da embarcação ao final da viagem.

Aplicando os custos enumerados pelos autores (Christiansen et al., 2007, Wang et al., 2017, Moreira, 2008 e Diz et al., 2014) no contexto do presente trabalho, tem-se que para alocar custos de um navio TCP a uma operação de abastecimento, deve-se verificar:

- Quanto tempo de aluguel do navio foi atribuído exclusivamente à operação de abastecimento,

- Se houve gasto de combustível para realizar o próprio abastecimento, ou seja, se foi necessário navegar fora da rota de transporte de produtos para se alcançar o ponto de abastecimento e

- Quais despesas portuárias foram necessárias especificamente para realizar o abastecimento.

A Tabela 2 resume os itens de custos mencionados nos estudos citados nas três subseções da revisão da literatura.

Tabela 2 - Itens de custos abordados na revisão da literatura.

\begin{tabular}{|c|c|c|c|c|c|c|c|c|}
\hline \multirow[b]{2}{*}{ Autores } & \multicolumn{8}{|c|}{ Itens de custos abordados nos estudos } \\
\hline & $\begin{array}{c}\text { Preço do } \\
\text { combustível }\end{array}$ & $\begin{array}{l}\text { Movimentação } \\
\text { de produto }\end{array}$ & Barcaça & $\begin{array}{l}\text { Aluguel da } \\
\text { embarcação }\end{array}$ & $\begin{array}{l}\text { Consumo de } \\
\text { combustível }\end{array}$ & $\begin{array}{c}\text { Custos } \\
\text { Portuários }\end{array}$ & $\begin{array}{l}\text { Frete } \\
\text { (VCP) }\end{array}$ & $\begin{array}{c}\text { Demurrage } \\
\text { (VCP) }\end{array}$ \\
\hline Besbes e Savin (2009) & $\mathrm{x}$ & & & & & & & \\
\hline Wang et al. (2014) & $x$ & & & & & & & \\
\hline Darnell et al. (1977) & $x$ & & & & & & & \\
\hline Zockaie et al. (2016) & & & & $x$ & $x$ & & & \\
\hline Suzuki et al., 2013 & $x$ & & & & & & & \\
\hline Zhen et al. (2017) & $x$ & & & & & & & \\
\hline Drake (2003) & & $x$ & $x$ & & & $x$ & & \\
\hline Christiansen et al. (2007) & & & & $x$ & $x$ & $x$ & & \\
\hline Wang et al. (2017) & & & & $x$ & $x$ & $x$ & & \\
\hline Scofield (2011) & & & & & & & $x$ & $\mathrm{x}$ \\
\hline Moreira (2008) & & & & $x$ & $x$ & $x$ & $x$ & $x$ \\
\hline Diz et al. (2014) & & & & $x$ & $x$ & $x$ & $x$ & $x$ \\
\hline
\end{tabular}

Fonte: A autora.

O próximo capítulo descreve a metodologia utilizada no presente trabalho, detalhando os métodos de coleta e análise de dados e a validação de resultados aplicados para modelar os custos de abastecimento da Petrobras e desenvolver fluxo de decisão padrão de onde e quanto abastecer. 


\section{3}

\section{Metodologia}

O trabalho consiste em uma pesquisa ação para modelagem de custos e proposta de procedimento de tomada de decisão para o caso prático dos abastecimentos da frota de cabotagem de petróleo e derivados da Petrobras.

Huang (2010) define pesquisa ação como uma orientação transformativa para criação de conhecimento em um contexto de prática, no qual pesquisadores trabalham com praticantes. Em se tratando de estudo conduzido por membro da equipe de programação de navios de cabotagem de derivados, em contato diário com a equipe de operação de navios e frequente interface com as áreas Comercial de bunker e Afretamento, a pesquisa ação se mostrou como metodologia adequada para sua condução.

Segundo Westbrook (1995), a pesquisa ação não tem em seu pesquisador um observador independente, mas um participante - de forma que o processo de mudança se torna o objeto da pesquisa. Westbrook (1995) também propõe um modelo de pesquisa ação com interações nas etapas da fase de implementação, dado que cada aplicação pode levar a alterações no foco da pesquisa ou mesmo a novo desenvolvimento de teorias. O modelo pode ser observado na Figura 2.

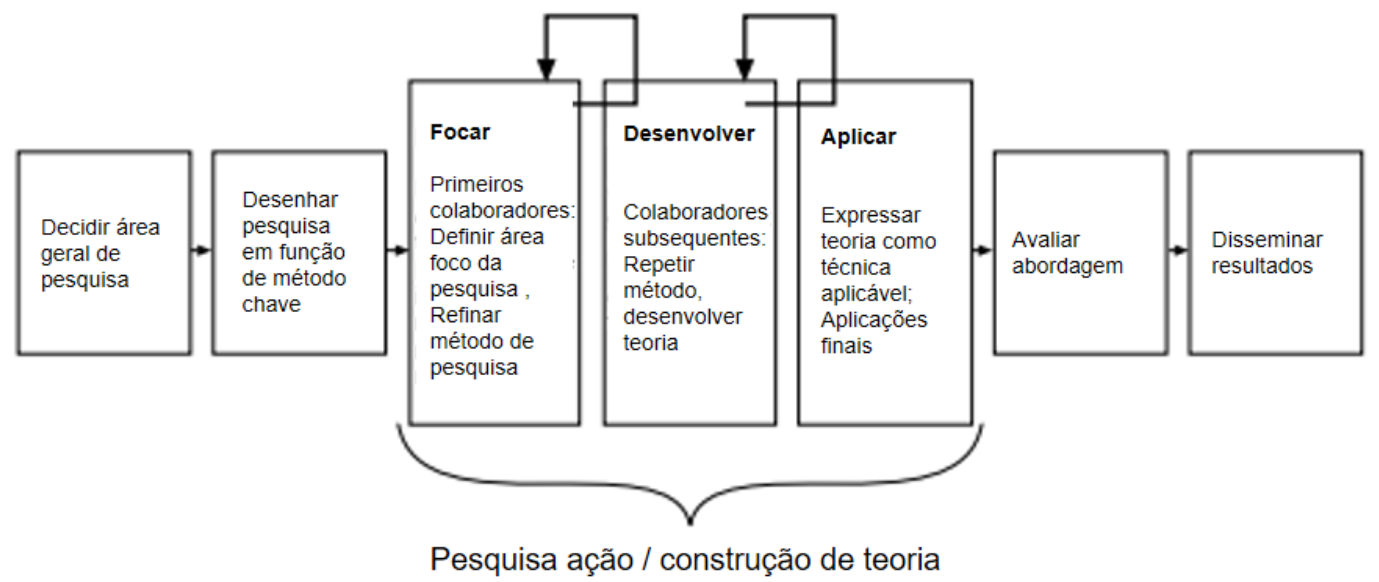

Figura 2 - Modelo de pesquisa ação.

Fonte: Adaptado de Westbrook (1995).

As próximas seções tratarão de como as etapas descritas por Westbrook (1995) foram aplicadas no presente trabalho. 


\section{1}

\section{Unidade de análise}

O presente trabalho tem como unidade de análise o processo de abastecimento das embarcações da frota de cabotagem da Petrobras. Atualmente, o pedido de abastecimento é feito pela área de operação de navios à área de comercialização de bunker. Embora os impactos em custos façam parte dos conhecimentos tácitos dos operadores, que possuem liberdade para propor o abastecimento de uma embarcação em condições favoráveis à Petrobras, o processo mapeado em sistema interno na companhia (Figura 3) prevê o pedido de abastecimento como uma resposta a uma solicitação da tripulação da embarcação.

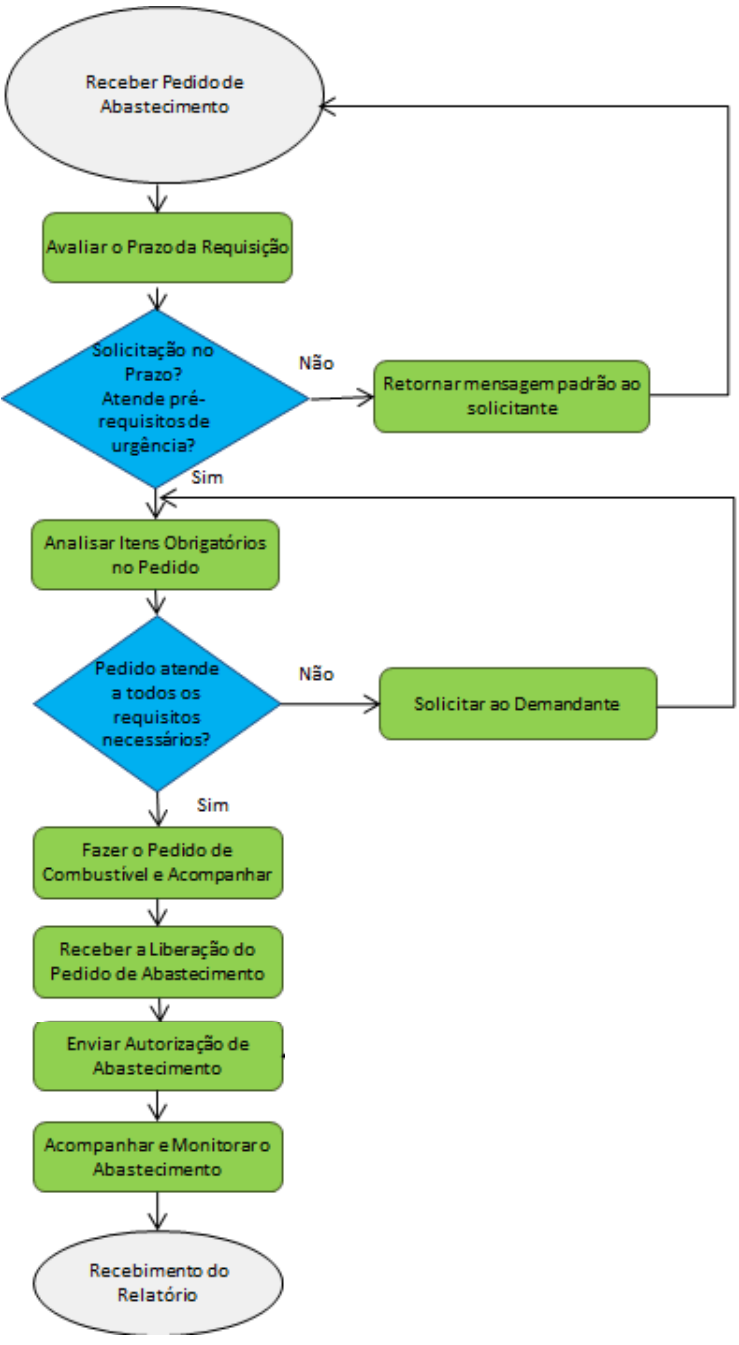

Figura 3 - Processo de Pedido de Abastecimento.

Fonte: Petrobras.

Isso significa que não há orientação formal da empresa a respeito de como a tomada de decisão de quando e onde abastecer os navios deve ser feita, podendo 
inclusive ser delegada às tripulações dos navios, independentemente de seu impacto logístico à companhia. O processo ilustrado também explicita a existência de prazo para a requisição de abastecimento. A possibilidade de não atendimento à antecedência exigida pela área comercial de bunker pode representar a não realização de um pedido de abastecimento econômico, podendo inclusive se desdobrar em uma necessidade de desvio de rota para abastecimento no futuro.

Os custos de abastecimento de navios para a empresa não são acompanhados e controlados de forma específica, e sim agregados com outros custos de transporte marítimo, dificultando a identificação das causas dos abastecimentos mais onerosos e a avaliação das decisões tomadas. Fatores como as nuances entre cada porto referente às despesas portuárias, histórico de tempo de espera por terminal e consumo médio de combustível por porte de navio devem ser direcionadores da melhor decisão de onde abastecer o navio. Assim, o levantamento desses dados e mapeamento de sua interferência conjunta deve trazer ganhos nas tomadas de decisão da empresa.

\section{2}

\section{Fontes de informação e métodos de coleta de dados}

A pesquisa conciliou como fontes de informação dados coletados em seus sistemas nativos e bancos de dados com entrevistas realizadas com as equipes de logística e comercialização da empresa.

As entrevistas foram realizadas com especialistas dos tópicos estudados, dentre gerentes, coordenadores, consultores e analistas com experiência entre cinco e trinta anos na atividade. As entrevistas direcionadas para levantamento de dados foram elaboradas para os conhecimentos específicos de cada área abordada, como questões de custos portuários para a gerência de Gestão de Contratos Logísticos, questões de custos de transporte marítimo para a gerência de Afretamento e questões operacionais de abastecimento para a gerência de Operações e Serviços da área comercial de bunker. Já as entrevistas para seleção de novos pontos de abastecimento e validação de metodologia foram replicadas para membros de diferentes equipes a fim de se obter uma perspectiva mais ampla. 
Para a condução da pesquisa ação, foram levantadas todas operações de carga e descarga de petróleo, gás natural, GLP e derivados nos navios afretados pela modalidade TCP no Brasil no ano de 2017. Os dados foram levantados em um sistema de informação nativo da empresa (SIGO II), em que são registradas características operacionais das embarcações, as datas e horas de chegada e saída de cada navio em cada terminal, a disponibilidade de bunker de cada navio em cada escala, bem como as atividades realizadas.

A partir das operações levantadas foram listados os pontos operacionais utilizados para carga e descarga de produtos no Brasil. Foi verificado junto à área que operacionaliza as entregas de bunker quais pontos operacionais dispõem de estrutura para abastecimento e em quais modalidades.

Dentre os pontos sem abastecimento disponível, foram levantados quais não teriam viabilidade de realizar abastecimento por restrição operacional e quais poderiam ser considerados novos pontos em potencial. A Tabela 3 apresenta a classificação dos pontos de acordo com o critério estabelecido. A lista completa de pontos operacionais no Brasil e suas classificações pode ser consultada no Apêndice 1 - Detalhamento de Pontos Operacionais.

Tabela 3 - Disponibilidade de abastecimento por tipo de ponto operacional.

\begin{tabular}{|c|c|c|c|c|}
\hline Tipo Ponto Operacional & Disponível & Potencial & Inviável & Total \\
\hline Plataforma & 0 & 0 & 41 & 41 \\
\hline Terminal & 14 & 10 & 0 & 24 \\
\hline Monoboia & 0 & 0 & 8 & 8 \\
\hline Total & 14 & 10 & 49 & 73 \\
\hline
\end{tabular}

Fonte: A autora.

Para os portos com abastecimento disponível, foram levantados junto às áreas de comercialização de bunker e operação de navios todos os cenários operacionais que podem ocorrer em um abastecimento de navio. As conclusões deste levantamento serão descritas na Seção 4.1. Em seguida, foram elencados os custos que podem incidir em cada situação de abastecimento. Foram levantados os dados referentes a custos de abastecimento junto às áreas operacionais envolvidas no processo.

Além disso, foram levantadas informações do sistema integrado de gestão empresarial referentes às entregas de bunker realizadas em 2017, com dados referentes a quantidade entregue e modal utilizado. 
Outros documentos foram levantados para evidenciar o interesse da companhia na redução de consumo de bunker e potenciais investimentos em novos pontos de abastecimento. Esses levantamentos foram feitos na intranet e através de correio eletrônico.

\section{3}

\section{Métodos de análise}

Diferentes métodos de análise foram conciliados para avaliar os impactos em custos para a Petrobras do processo de abastecimentos de navios da cabotagem. Para alcançar os objetivos principal e específicos deste trabalho, seis etapas foram conduzidas, cada uma se baseando em diversos métodos de análise. As etapas estão resumidas na Tabela 4.

Tabela 4 - Etapas da Pesquisa Ação.

\begin{tabular}{cl}
\hline Etapa & \multicolumn{1}{c}{ Descrição } \\
\hline 1. & Desenvolvimento do modelo de custos de abastecimento \\
2. & Elaboração de ferramenta de apoio à decisão de onde e quanto abastecer \\
3. & Cálculo do custo realizado de abastecimentos da frota de cabotagem em 2017 \\
4. & Elaboração de fluxo de decisão de abastecimento padronizado \\
5. & Cálculo da economia nos abastecimentos das rotas de 2017 com o procedimento proposto \\
6. & Avaliação de economia com inclusão de novos pontos de abastecimento
\end{tabular}

Fonte: A autora.

A revisão da literatura detalhada no Capítulo 2 permitiu verificar o que já se havia estudado na academia sobre o assunto e explicitar dentro da empresa as preocupações com custos e gasto de combustível. Através de análise documental e entrevistas com as equipes especialistas, foi possível verificar no detalhe quais as nuances operacionais entre as diferentes situações de abastecimento e quais os itens de custos incidentes para cada uma delas. Os dados levantados foram analisados em planilha Excel, gerando um modelo do cenário atual de abastecimentos para a frota da Petrobras, mapeando os custos fixos e variáveis incidentes para cada ponto operacional, situação de abastecimento e porte de navio (Etapa 1).

O modelo de custos realizado serviu como base para o desenvolvimento de um protótipo de ferramenta para utilização da equipe operacional da Petrobras (Etapa 2), contemplando: 
- um simulador de custos, que categoriza para uma determinada operação de abastecimento quais as parcelas incidentes e o custo total esperado e

- uma ferramenta de apoio à decisão, que lista as situações de abastecimento por porto em ordem crescente de custos para um par origem x destino dados pelo usuário.

A ferramenta permite que alguns parâmetros sejam alterados pelo usuário, como a velocidade de navegação da embarcação e o tempo de espera estimado de cada porto, podendo representar no momento da utilização quaisquer particularidades operacionais que estejam ocorrendo.

O protótipo foi desenvolvido em uma planilha do Microsoft Excel e posteriormente será disponibilizado para a força de trabalho através da plataforma TIBCO Spotfire, que permite facilmente a publicação do painel e acesso pela equipe da Logística da Petrobras.

Até o momento, a decisão de onde abastecer os navios da frota não era apoiada por nenhuma ferramenta e havia pouca transparência a respeito dos custos incidentes para os tomadores de decisão. Com o produto desenvolvido, a transparência é assegurada e os operadores podem afirmar que a decisão foi tomada em conformidade com as orientações de redução de custos operacionais da empresa.

Outro método de análise importante foi a observação participativa, que envolveu desde o acompanhamento de operações de abastecimento na Baía de Guanabara quanto o impacto na atividade de programação de navios por falta de autonomia de navegação de determinadas embarcações. A observação participativa, junto das entrevistas com as equipes da logística, foram essenciais no desenvolvimento de proposta de fluxo de decisão padronizado para os abastecimentos da frota (Etapa 4). O fluxo proposto atribuiu volumes de abastecimento previstos para as escalas em cada porto, a partir de uma classificação dos portos com abastecimento disponível por custo operacional. Essa classificação surgiu de uma análise de sensibilidade dos custos mapeados, alterando os volumes abastecidos e portes de embarcações, a fim de se equilibrar a influência dos custos fixos e variáveis na classificação.

Para a análise das rotas de 2017 (Etapas 3, 5 e 6), novamente através de planilhas foram estimados os custos de abastecimento do Cenário Realizado como 
de diversos cenários propostos para o fluxo de decisão desenvolvido. Os cenários propostos foram desenhados de forma a realizar contrapontos e análise de concordância entre os aspectos enumerados pelas equipes entrevistadas, tanto com relação ao interesse de utilização de pontos de abastecimento disponíveis (Etapa 5), quanto à inclusão de novos pontos de abastecimento (Etapa 6).

Os resultados observados pelos métodos descritos encontram-se no Capítulo 4. A próxima seção detalha o método de modelagem de custos desenvolvido.

\section{4}

\section{Modelagem de custos}

Por se tratar de empresa verticalizada que produz o próprio combustível que abastece os navios de sua frota, a modelagem de custos do serviço de abastecimento de navios da frota da Petrobras baseou-se em duas frentes:

- Visão fornecedor: custos referentes ao suprimento de bunker à frota, semelhantes aos custos de suprimento de bunker aos clientes externos e aos observados por Drake (2003) no abastecimento de navios da marinha em Pearl Harbor, descrito no Capítulo 2.

- Visão cliente: custos de transporte marítimo alocados ao abastecimento, referentes aos ajustes feitos nas operações das embarcações afretadas pela Petrobras para garantir seu abastecimento.

Como custos referentes ao suprimento, temos os custos de movimentação do bunker, incluindo as movimentações realizadas pela Petrobras, as cobranças do prestador de serviços logísticos e o custo com as barcaças abastecedoras afretadas. Já com relação aos custos de Transporte Marítimo, temos as parcelas dos custos de aluguel, consumo de bunker e custos portuários que devem ser atribuídas exclusivamente à atividade de abastecimento.

\subsection{1}

\section{Custos de suprimento de bunker - Petrobras enquanto fornecedora}

Nem todos os terminais equipados para fornecer bunker recebem o produto diretamente por um duto conectado à tancagem de uma refinaria. Em alguns 
portos o bunker é transportado por outro modal, como a própria cabotagem. Para estimar o custo de movimentação de bunker pela Petrobras referente às operações descritas, foram levantadas todas as viagens de cabotagem de bunker realizadas em 2017. Essas viagens tiveram seus custos estimados de acordo com os fatores enumerados por Diz et al. (2014).

Como toda cabotagem de bunker é realizada com navios de um mesmo porte, considerou-se um mesmo custo de diária de aluguel de navio e uma mesma taxa de consumo de bunker em tonelada por dia de navegação. Essas informações foram levantadas como um custo médio para o porte de navio utilizado nessas rotas. Os custos portuários foram levantados por porto e porte de navio.

Com essas informações foi levantado para cada rota o custo da viagem completa e, em seguida, o custo da viagem foi rateado pela quantidade transportada, gerando um custo de movimentação por tonelada. Em determinadas rotas o custo de reposição do navio foi nulo, dada a oportunidade de carregar outro produto (como óleo combustível industrial) na mesma escala realizada para descarga de bunker. A Figura 4 ilustra três exemplos de rotas de cabotagem de bunker para o porto de Paranaguá com a reposição do navio no porto de carga seguinte.

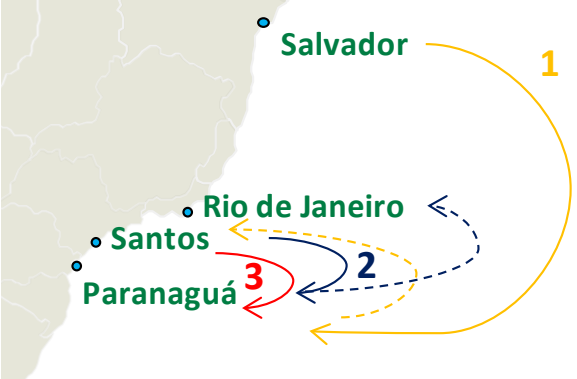

Legenda

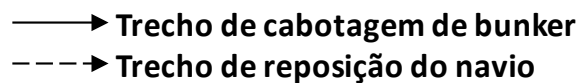

Figura 4 - Exemplos de rotas de cabotagem de bunker para o porto de Paranaguá Fonte: A autora.

Após o levantamento do custo de cada uma das rotas de cabotagem de bunker de 2017, foram agrupados os custos por tonelada para cada porto de destino, gerando um custo médio para cada porto. Para os portos que recebem o combustível por ferrovia, o custo de movimentação de bunker foi representado como o custo por tonelada previsto em contrato com prestador de serviços logísticos. 
Os demais portos são conectados por dutos às refinarias produtoras de bunker, não havendo custo de movimentação adicional às tarifas de transporte em dutos e armazenagem em tanque de terra pela Transpetro, aplicáveis a todos os terminais. As cobranças da Transpetro são feitas de acordo com tabela disponível no site da empresa, conforme Anexo 1.

Já o custo referente à movimentação da barcaça foi averiguado com as gerências de operação de bunker e de afretamento de embarcações. As barcaças abastecedoras são afretadas em sua maioria na modalidade COA (Contract of Affreightment), onde a cobrança é por tonelada movimentada. Conforme visto em Cristo (2014), descrito no Capítulo 2, as barcaças e seus abastecimentos são gerenciados por prestadoras de serviço de transporte e entrega de bunker contratadas pela Petrobras. Assim, os custos de atracação da barcaça no píer, inspeção de segurança e cercamento para prevenção de vazamentos são de responsabilidade do transportador e remunerados pela própria cobrança volumétrica.

Vale ressaltar que, de forma semelhante ao duplo manuseio descrito por Drake (2003), também visto no Capítulo 2, os custos operacionais referentes ao volume movimentado no duto da Transpetro ocorrem independentemente se o produto vai do tanque de terra diretamente ao navio que será abastecido (abastecimento por duto) ou do tanque de terra à barcaça abastecedora (abastecimento por barcaça). Dessa forma, o abastecimento por barcaça é necessariamente mais caro que o abastecimento por duto, e a diferença de custo entre essas modalidades pode ser representado pelo custo de movimentação do COA. A Tabela 5 resume os custos de suprimento de bunker aplicáveis para cada porto com abastecimento disponível. 
Tabela 5 - Custos de suprimento de bunker aplicáveis por porto.

\begin{tabular}{llccc}
\hline Porto & UF & $\begin{array}{c}\text { Armazenagem e } \\
\text { Movimentação } \\
\text { Dutoviária }\end{array}$ & $\begin{array}{c}\text { Transporte } \\
\text { (Marítimo ou } \\
\text { Ferroviário) }\end{array}$ & $\begin{array}{c}\text { Custo do } \\
\text { COA* }\end{array}$ \\
\hline MANAUS & AM & $\mathrm{X}$ & & \\
BELEM & $\mathrm{PA}$ & $\mathrm{X}$ & $\mathrm{X}$ & $\mathrm{X}$ \\
VILA DO CONDE & $\mathrm{PA}$ & $\mathrm{X}$ & $\mathrm{X}$ & $\mathrm{X}$ \\
FORTALEZA & $\mathrm{CE}$ & $\mathrm{X}$ & & \\
SALVADOR & $\mathrm{BA}$ & $\mathrm{X}$ & & $\mathrm{X}$ \\
ARATU & $\mathrm{BA}$ & $\mathrm{X}$ & & $\mathrm{X}$ \\
TUBARAO & $\mathrm{ES}$ & $\mathrm{X}$ & $\mathrm{X}$ & $\mathrm{X}$ \\
VITORIA & $\mathrm{ES}$ & $\mathrm{X}$ & $\mathrm{X}$ & $\mathrm{X}$ \\
RIO DE JANEIRO & $\mathrm{RJ}$ & $\mathrm{X}$ & & $\mathrm{X}$ \\
ANGRA DOS REIS & $\mathrm{RJ}$ & $\mathrm{X}$ & $\mathrm{X}$ & \\
SAO SEBASTIAO & $\mathrm{SP}$ & $\mathrm{X}$ & $\mathrm{X}$ & \\
SANTOS & $\mathrm{SP}$ & $\mathrm{X}$ & & $\mathrm{X}$ \\
PARANAGUA & $\mathrm{PR}$ & $\mathrm{X}$ & $\mathrm{X}$ & $\mathrm{X}$ \\
RIO GRANDE & $\mathrm{RS}$ & $\mathrm{X}$ & $\mathrm{X}$ & $\mathrm{X}$ \\
\hline \multicolumn{5}{l}{ RAplicável apenas para abastecimentos por barcaça }
\end{tabular}

Fonte: A autora.

\subsection{2}

\section{Custos de transporte marítimo - Frota Petrobras enquanto cliente}

De forma semelhante aos custos de cabotagem de bunker, os custos transporte marítimo gerados pelas operações de abastecimento são compostos pelos custos de aluguel, consumo de combustível e custos portuários.

Para os custos portuários, estamos interessados nas despesas atribuíveis exclusivamente ao abastecimento. No momento em que um navio acrescenta um porto à sua rota apenas para abastecer, teremos todos os custos portuários dessa escala associados ao seu abastecimento. Já quando o navio opera no píer e fundeia na sequência para abastecer - operação detalhada na seção 4.1.1, há um acréscimo no custo de praticagem referente à manobra de fundeio.

Para isso foram levantados os custos portuários de todos portos que oferecem a possibilidade de abastecer, verificando junto à gerência responsável quais despesas são adicionais a cada situação. Vale ressaltar que os custos portuários variam de acordo com o porte da embarcação. Como a frota de petróleo 
e derivados envolve navio de diversos portes, o levantamento precisou englobar as despesas de cada porto para cada categoria de porte utilizada.

A constatação do quanto a operação de abastecimento tomaria de tempo de aluguel do navio e do consumo adicional de combustível em situações de desvio de rota também dependem do momento em que é feito o abastecimento. Percebese, então, que a incidência dos custos de transporte marítimo depende fortemente da situação de abastecimento. A próxima seção detalha como os custos foram modelados de acordo com sua aplicabilidade à cada situação.

\subsection{3}

Incidência de custos por situação de abastecimento

Podemos resumir os abastecimentos de navios em três situações:

a. Abastecimento por duto (navio atracado);

b. Abastecimento por barcaça a contrabordo (navio atracado);

c. Abastecimento por barcaça no fundeio (navio fundeado).

Todavia, há diferença significativa nos custos incidentes caso o abastecimento ocorra em uma escala de carga ou descarga de produto ou seja necessário acrescentar uma escala à rota exclusivamente para realização do abastecimento. Assim, os três casos são desdobrados em seis situações de abastecimento, sendo elas:

a. Duto simultâneo: abastecimento por duto simultaneamente à operação;

b. Contrabordo simultâneo: abastecimento por barcaça a contrabordo simultaneamente à operação;

c. Fundeio para operação: abastecimento por barcaça no fundeio imediatamente antes ou após operação;

d. Duto exclusivo: abastecimento por duto em escala realizada exclusivamente para abastecer;

e. Contrabordo exclusivo: abastecimento por barcaça a contrabordo em escala realizada exclusivamente para abastecer;

f. Fundeio exclusivo: abastecimento por barcaça no fundeio em escala realizada exclusivamente para abastecer. 
Vale ressaltar que na prática a situação "Fundeio exclusivo" ocorre com frequência muito superior à alternativa "Duto exclusivo", enquanto a alternativa "Contrabordo exclusivo" tem histórico nulo nos últimos anos. Todavia, para fins de modelagem de cenários de custos, não será descartada essa possibilidade, deixando as ferramentas desenvolvidas avaliarem o interesse econômico da mesma.

A Tabela 6 resume as situações, detalhando os modais de abastecimento, a posição do navio e o momento do abastecimento de cada uma.

Tabela 6 - Situações de abastecimento.

\begin{tabular}{llll}
\hline Situação & Modal & Navio & Escala \\
\hline Duto simultâneo & Duto & Atracado & Com operação \\
Contrabordo simultâneo & Barcaça & Atracado & Com operação \\
Fundeio para operação & Barcaça & Fundeado & Com operação \\
Duto exclusivo & Duto & Atracado & Sem operação \\
Contrabordo exclusivo & Barcaça & Atracado & Sem operação \\
Fundeio exclusivo & Barcaça & Fundeado & Sem operação \\
\hline
\end{tabular}

Fonte: A autora.

Para cada situação de abastecimento descrita incidem mais ou menos custos operacionais. Os custos foram agregados e classificados da seguinte forma:

- Movimentação de Produto: compreende as tarifas cobradas pelo operador logístico por armazenar e movimentar e combustível em suas instalações, além de envolver o custo de transporte marítimo ou ferroviário para os combustíveis que são transferidos entre refinarias e terminais distantes entre si.

- Barcaça: corresponde ao custo de tonelada movimentada pela barcaça conforme o COA.

- Excesso de estadia: corresponde ao custo do tempo adicional do navio no porto abastecedor comparativamente a uma viagem hipotética sem abastecimento. O custo é representado pela diária do aluguel do TCP multiplicado pelo tempo do atraso em dias. Esse custo de oportunidade significa que, caso a estadia fosse menor, o navio poderia ser utilizado em outro transporte - inclusive para terceiros (sublocação do ativo). 
- Manobras adicionais: corresponde às despesas portuárias incidentes por manobra, como custos de rebocador, praticagem e lancha de apoio, que podem incidir uma ou duas vezes mais de acordo com a situação de abastecimento. Conforme será detalhado na seção 4.1, caso o navio se dirija ao fundeio antes ou após a atracação para carga ou descarga, há incidência de uma manobra adicional. Já em portos fora da rota, há incidência de duas manobras adicionais (entrada e saída do píer ou do fundeio).

- Entrada no porto: corresponde às despesas portuárias incidentes na entrada de um navio no porto, como Livre Prática, TUF e FUNAPOL, que ocorrem adicionalmente quando o navio acrescenta um porto à sua rota apenas para abastecer.

- Desvio de rota: corresponde ao custo de navegação adicional do navio para se direcionar ao porto de abastecimento. $\mathrm{O}$ custo de desvio é aplicável às escalas sem operação, porém pode ser nulo caso o porto de abastecimento esteja entre portos da rota de transporte de carga.

A Tabela 7 associa para cada situação de abastecimento quais os custos aplicáveis.

Com os métodos relatados na seção 3.2, foram levantados os custos fixos e variáveis incidentes em cada porto, situação de abastecimento e porte de navio. Os custos foram organizados de forma a gerar um modelo capaz de estimar o custo da operação de abastecimento em função do volume abastecido, local do abastecimento, porto de origem, porto de destino e porte do navio.

Tabela 7 - Custos aplicáveis por situação de abastecimento.

\begin{tabular}{|c|c|c|c|c|c|c|}
\hline \multirow[b]{2}{*}{ Situação } & \multicolumn{6}{|c|}{ Custos Aplicáveis } \\
\hline & $\begin{array}{c}\text { Movimentação } \\
\text { de produto }\end{array}$ & Barcaça & $\begin{array}{c}\text { Excesso } \\
\text { de estadia }\end{array}$ & $\begin{array}{l}\text { Manobras } \\
\text { adicionais }\end{array}$ & $\begin{array}{l}\text { Entrada } \\
\text { no porto }\end{array}$ & $\begin{array}{l}\text { Desvio } \\
\text { de rota }\end{array}$ \\
\hline Duto simultâneo & $\mathrm{x}$ & & & & & \\
\hline Contrabordo simultâneo & $x$ & $x$ & & & & \\
\hline Fundeio para operação & $x$ & $x$ & $x$ & $x$ & & \\
\hline Duto exclusivo & $x$ & & $x$ & $2 x$ & $x$ & $x$ \\
\hline Contrabordo exclusivo & $x$ & $x$ & $x$ & $2 x$ & $x$ & $x$ \\
\hline Fundeio exclusivo & $x$ & $x$ & $x$ & $2 x$ & $x$ & $x$ \\
\hline
\end{tabular}

Fonte: A autora. 
O modelo agrupou todos os custos considerados variáveis, como os custos de movimentação e armazenagem da Transpetro e os custos da barcaça, mas também algumas tarifas portuárias que variam com a tonelada movimentada.

Para os custos de entrada no porto e manobra, foi feito um mapeamento de quais parcelas de custos seriam incidentes em cada situação. Já para o excesso de estadia foi verificado junto à equipe de planejamento logístico o tempo médio histórico de espera por porto, com o objetivo de estimar o quanto do aluguel foi associado a uma operação de abastecimento não simultânea às atividades de carga e descarga.

Por fim, para verificar os custos de desvio de rota para aquelas situações em que ele ocorre, foram levantadas as distâncias entre os portos operados pela Petrobras. Os portos foram sequenciados de acordo com sua posição na costa, a fim de determinar se cada porto considerado para abastecer está localizado entre a origem e o destino do transporte da carga ou se será necessário desviá-lo. Esse desvio também considerou o preço do bunker e a cotação do dólar a fim de estimar as perdas por consumo adicional, refletindo o custo de oportunidade de venda desse volume de bunker consumido.

Em seguida, foram levantados junto à área que operacionaliza as entregas de bunker quais portos dispõem de estrutura para abastecimento e em quais modalidades. O levantamento gerou a Tabela 8, que cruza os portos com abastecimento disponível com as situações de abastecimento viáveis em cada porto.

De maneira geral, a situação "Duto exclusivo" é aplicável onde a situação "Duto simultâneo" é aplicável e a mesma correspondência ocorre entre "Contrabordo exclusivo" e "Contrabordo simultâneo" e entre "Fundeio exclusivo" e "Fundeio para operação". As exceções ocorrem em portos que compartilham uma mesma área de fundeio. Nesses casos, a área de fundeio só foi representada na situação “Fundeio Exclusivo” para um dos portos que usufruem da mesma. 
Tabela 8 - Situações de abastecimento por porto.

\begin{tabular}{|c|c|c|c|c|c|c|}
\hline Porto & $\begin{array}{c}\text { Duto } \\
\text { simultâneo }\end{array}$ & $\begin{array}{c}\text { Contrabordo } \\
\text { simultâneo }\end{array}$ & $\begin{array}{c}\text { Fundeio } \\
\text { para operação }\end{array}$ & $\begin{array}{c}\text { Duto } \\
\text { exclusivo }\end{array}$ & $\begin{array}{c}\text { Contrabordo } \\
\text { exclusivo }\end{array}$ & $\begin{array}{r}\text { Fundeio } \\
\text { exclusivo }\end{array}$ \\
\hline MANAUS & $\mathrm{x}$ & & & $x$ & & \\
\hline BELEM & $x$ & $x$ & $x$ & $x$ & $x$ & $x$ \\
\hline VILA DO CONDE & & $x$ & $x$ & & $x$ & \\
\hline FORTALEZA & $x$ & & & $x$ & & \\
\hline SALVADOR & $x$ & & $x$ & $x$ & & $x$ \\
\hline ARATU & & & $x$ & & & \\
\hline TUBARAO & $x$ & $x$ & & $x$ & $x$ & \\
\hline VITORIA & & $x$ & & & $x$ & \\
\hline RIO DE JANEIRO & $x$ & $x$ & $x$ & $x$ & $x$ & $x$ \\
\hline ANGRA DOS REIS & $x$ & & & $x$ & & \\
\hline SAO SEBASTIAO & $x$ & & & $x$ & & \\
\hline SANTOS & $x$ & $x$ & & $x$ & $x$ & \\
\hline PARANAGUA & $x$ & $x$ & $x$ & $x$ & $x$ & $x$ \\
\hline RIO GRANDE & $x$ & $x$ & $x$ & $x$ & $x$ & $x$ \\
\hline
\end{tabular}

Fonte: A autora.

\subsection{4}

\section{Custo realizado de 2017}

Após o mapeamento de custos por situação de abastecimento, foi estimado o custo realizado nos abastecimentos da frota de cabotagem da Petrobras no ano de 2017. Foram cruzados os dados de rotas de cabotagem realizadas levantadas no sistema SIGO II com as informações referentes às entregas de bunker realizadas, do sistema integrado de gestão empresarial. Assim foi possível definir em que escalas cada navio abasteceu e qual foi o volume abastecido, bem como a informação do modal de abastecimento (duto ou barcaça). Correlacionando essas informações, a situação de abastecimento foi identificada para cada abastecimento realizado em 2017.

O custo realizado foi então calculado respeitando as classificações do modelo desenvolvido, multiplicando o volume abastecido pelo custo variável do porto e, quando sinalizado modal "barcaça”, pelo custo do COA. Os custos portuários, de excesso de estadia e desvio de rota só foram atribuídos às atividades de abastecimento nas escalas exclusivas para abastecimento. Nesses casos, o tempo total na escala e de desvio rota para atingimento do porto foi multiplicado pelos custos de aluguel da embarcação abastecida.

Vale ressaltar que na situação "Fundeio para operação" haveria uma manobra adicional a ser contabilizada pelo abastecimento no fundeio. Entretanto, 
em todas as escalas em que essa modalidade ocorreu, o abastecimento só foi realizado no fundeadouro pois os navios já se encontravam fundeados, aguardando liberação de píer para atracação. Dessa forma, os custos portuários e de estadia dessa situação foram atribuídos à atividade de transporte e não ao abastecimento.

Finalmente, todos os itens de custo mencionados foram somados para se encontrar o custo total de abastecimento realizado em 2017, cujos resultados estão detalhados no Capítulo 4.

\section{5}

\section{Desenvolvimento de fluxo de decisão}

A fim de buscar redução nos custos de abastecimento observados para as rotas de 2017, foram analisadas as ocorrências que mais impactaram no custo do cenário. Os dados foram levados às equipes de operação e programação a fim de determinar a causa raiz dessas ocorrências. As análises indicaram uma possibilidade de eliminar grande parte dessas ocorrências sem investimentos, simplesmente pela estruturação da decisão de abastecimento. Assim, foi elaborado um fluxo de decisão padronizado para simulação de aplicação nas rotas de 2017 e verificação de potenciais economias.

Para a definição do fluxo de decisão, foi efetuada uma análise de sensibilidade usando a ferramenta de apoio à decisão a fim de estipular os portos mais econômicos para abastecer. Foram listados em ordem crescente de custos os pontos de abastecimento para as situações "Duto simultâneo", “Contrabordo simultâneo" e "Fundeio para operação". Os custos das situações de abastecimento exclusivo foram desconsiderados, uma vez que o fluxo pretende evitar as escalas apenas para abastecer. A lista foi gerada para diferentes volumes de bunker, de forma a equilibrar os portos com custo variável mais elevado com aqueles com custo fixo mais elevado. Por fim repetiu-se o procedimento para todos os portes de embarcação utilizados na cabotagem, gerando uma classificação final de portos por ordem crescente de custos.

Os portos foram então agrupados em três categorias, cada uma com sua proposta de procedimento: 
1. Os portos de custo de abastecimento menor, tipicamente aqueles conectados por duto às refinarias produtoras de bunker, foram categorizados como “Abastecimento máximo”. Para eles propôs-se abastecer os navios até o máximo permitido, ou seja, a diferença entre a capacidade dos tanques de bunker do navio e a quantidade de bunker existente no navio na chegada ao porto.

2. Os portos com faixa de custo intermediária foram categorizados como “Abastecimento intermediário”. Para essa categoria foi proposto um abastecimento equivalente a dez dias de navegação, período adequado para percorrer boa parte da costa nacional. Caso o navio chegasse a um porto de categoria intermediária com estoque de bunker alto e não houvesse espaço em tanque para o volume proposto, o navio deve abastecer o volume equivalente ao espaço em tanque.

3. Por fim, para os portos mais onerosos os navios apenas abasteceriam o estritamente necessário para alcançar um porto econômico ou intermediário mais um volume estipulado de 150 toneladas, volume equivalente a dois a cinco dias de navegação, para garantir estoque de segurança. Esta última regra se assemelha a uma das restrições do modelo de Zhen et al. (2017) que verifica a autonomia da embarcação até o porto seguinte. Todavia, como não há abastecimento disponível em todos os portos das rotas de cabotagem, foi necessário adaptá-la para verificar a autonomia até o próximo ponto da rota com abastecimento disponível. Esses portos foram categorizados como “Abastecimento Mínimo”.

Caso qualquer uma das três regras acima indicasse abastecimento inferior a 150 toneladas, o abastecimento era automaticamente cancelado, de forma a representar no procedimento um volume mínimo que justificasse a mobilização para a operação de abastecimento.

O fluxo de decisão possui uma ressalva: para o porto de Fortaleza, é necessário verificar junto ao armador da embarcação se é possível realizar abastecimento com bunker de teor de acidez elevada. 
Após validado o procedimento, foram gerados os custos dos cenários propostos a se comparar com o custo realizado. Para isso, os dados de escalas realizadas pela frota de cabotagem em 2017 receberam novas indicações de abastecimento e volume a abastecer seguindo o fluxo de tomada de decisão descrito.

\section{6}

\section{Validação dos resultados}

Para garantir a validade dos dados utilizados, foi feita triangulação entre as informações disponíveis no sistema SIGO II com aquelas disponíveis no sistema integrado de gestão. As operações abastecimento indicadas no sistema integrado faziam referência à embarcação abastecida, local e data de abastecimento. Já no SIGO II é possível verificar em que local a embarcação se encontrava em determinada data. Não foi verificada nenhuma inconsistência no escopo estudado.

Outra verificação realizada foi com relação ao volume abastecido (levantado no sistema integrado de gestão) e o volume de bunker disponível na embarcação ao chegar e sair de cada porto. Nesse caso alguns dados de bunker disponível estavam incompletos, mas pela verificação sequencial das rotas foi possível verificar que os dados preenchidos eram compatíveis com os abastecimentos e consumos realizados. Também foi possível calcular o bunker disponível nas escalas sem informação.

Para avaliar a validade interna do fluxo de decisão proposto, foram levados os dados analisados antes e após a aplicação do fluxo para as equipes de operação e programação. O fluxo foi ajustado para garantir aderência às particularidades operacionais da empresa, como a disponibilidade restrita de abastecimentos em Fortaleza e o custo variável elevado dos abastecimentos em Belém.

Com relação à validade externa, cabe ressaltar que a incidência dos itens de custos para cada situação de abastecimento modelada é replicável para demais empresas verticalizadas de energia. Todavia, outras situações de abastecimento além das aplicáveis à Petrobras podem ocorrer, como por exemplo o abastecimento em embarcações navegando. Além disso, as taxas portuárias variam de país para país e os custos de movimentação e de barcaça dependerão da 
organização da empresa estudada quanto a terceirização, disponibilidade de ativos etc.

O próximo capítulo detalha os resultados observados na aplicação de cada uma das etapas da pesquisa ação. 


\section{Aplicação e Resultados}

Neste capítulo é apresentado o contexto em que a pesquisa ação foi conduzida, bem como os resultados encontrados em cada etapa do trabalho com a aplicação da metodologia descrita no Capítulo 3.

\section{1}

\section{Contexto da pesquisa ação}

O bunker que abastece os navios do país é produzido nas refinarias da Petrobras e movimentado até tanque de terra dos terminais aquaviários. Em cada terminal com abastecimento disponível existem um ou mais tanques de terra onde o bunker é armazenado até a entrega. A tancagem do terminal é conectada ao píer por duto. A Figura 5 ilustra os tanques de terra de diversos produtos do terminal da Ilha d’Água, dentre eles os tanques de bunker.

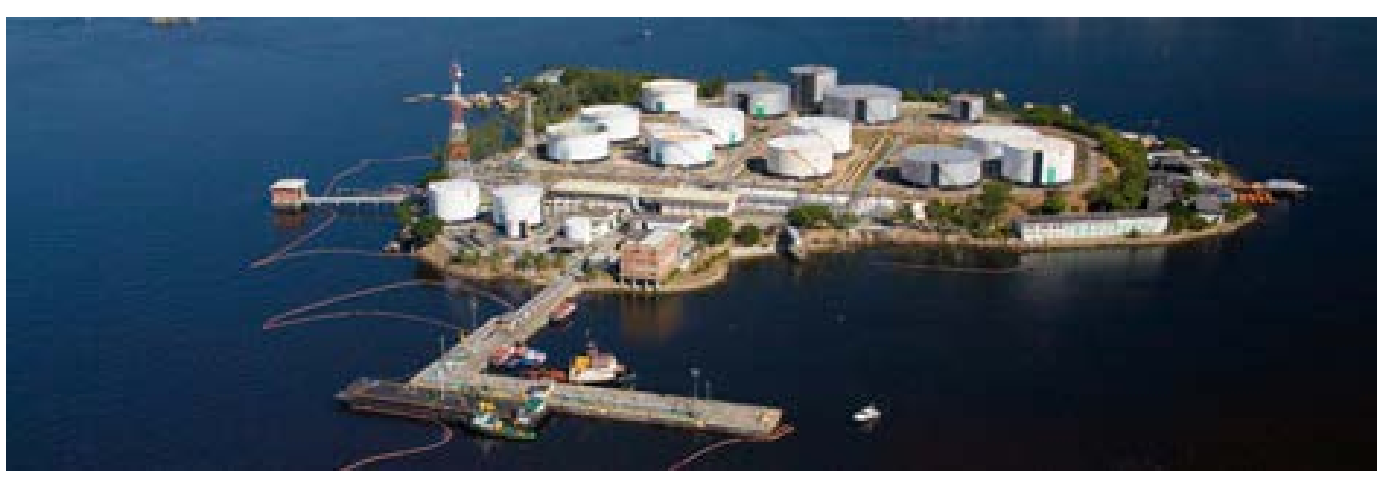

Figura 5 - Píer de Barcaças e Parque de Tanques na llha d'Água.

Fonte: http://www.petrobras.com.br.

A comercialização de bunker da Petrobras classifica as entregas em duas modalidades de abastecimento: pipe, para os abastecimentos realizados diretamente por duto em navios atracados no píer, e barge, para abastecimentos realizados por barcaças.

No abastecimento por duto, o navio atraca em um píer equipado para tal e é feita conexão entre o alinhamento de bunker do píer e o manifold do navio, seja por braço de carregamento ou mangote. Essa modalidade usualmente é utilizada 
para permitir que o navio realize o abastecimento de forma concomitante às operações de carga e descarga, uma vez que os custos e tempo envolvidos em uma atracação dificilmente são justificados por uma simples operação de abastecimento. A Figura 6 ilustra um navio atracado em píer.

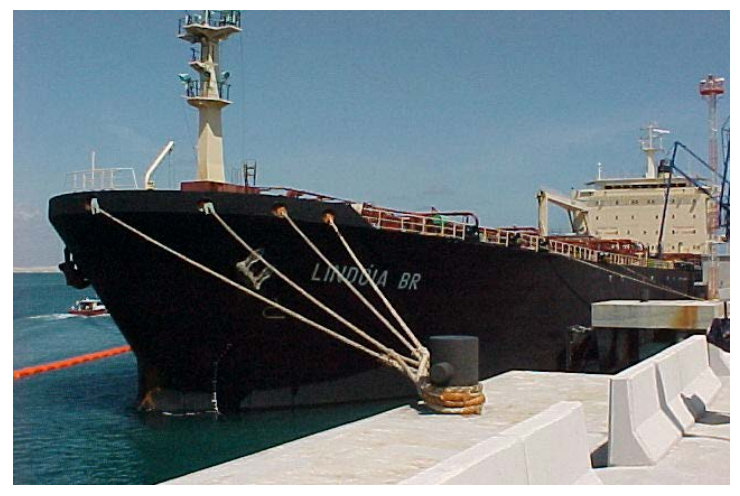

Figura 6 - Navio atracado em píer.

Fonte: Petrobras.

O abastecimento por duto é usufruído principalmente pela frota da Petrobras, dado que em sete dos onze portos que oferecem essa modalidade a operação de navios de terceiros é muito rara ou mesmo nula.

Assim, as entregas de bunker no país ocorrem majoritariamente na modalidade barge. Nessa modalidade, uma barcaça abastecedora carrega bunker no píer e em seguida é amarrada ao navio que será abastecido, conforme Figura 7. Em alguns terminais há píer exclusivo para carga de barcaça (exemplo visto na Figura 2), enquanto em outros há disputa de atracação com navios de pequeno porte, como navios de GLP, lubrificantes e asfalto.

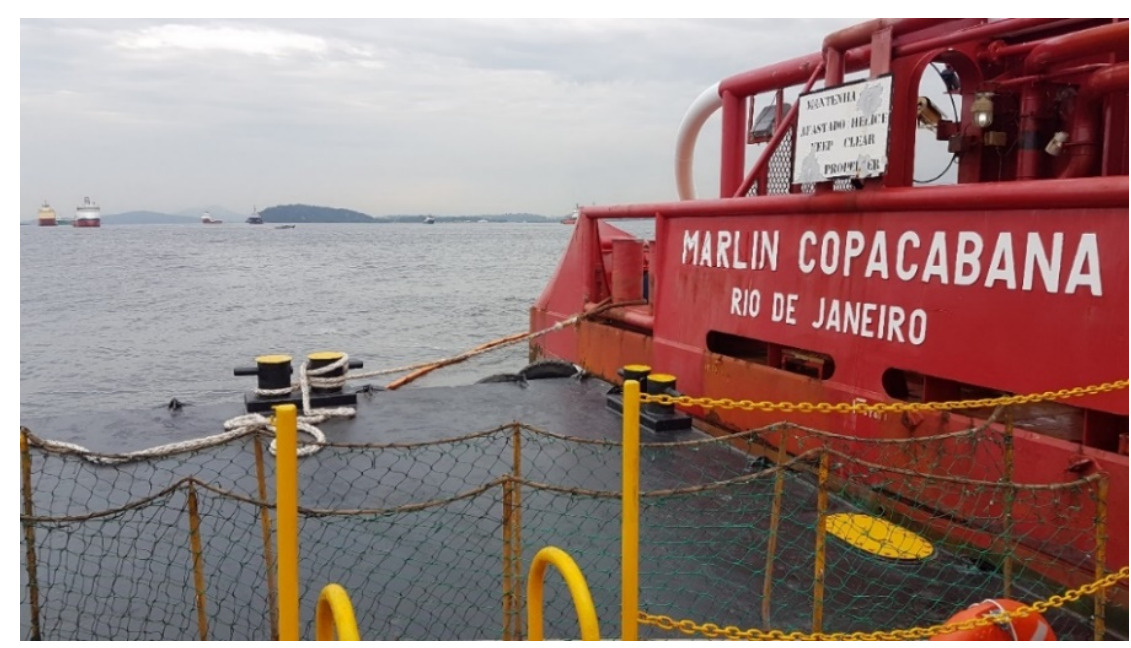

Figura 7 - Barcaça amarrada em navio.

Fonte: A autora. 
Após a amarração, uma equipe conecta por mangote os manifolds das embarcações, conforme Figura 8.

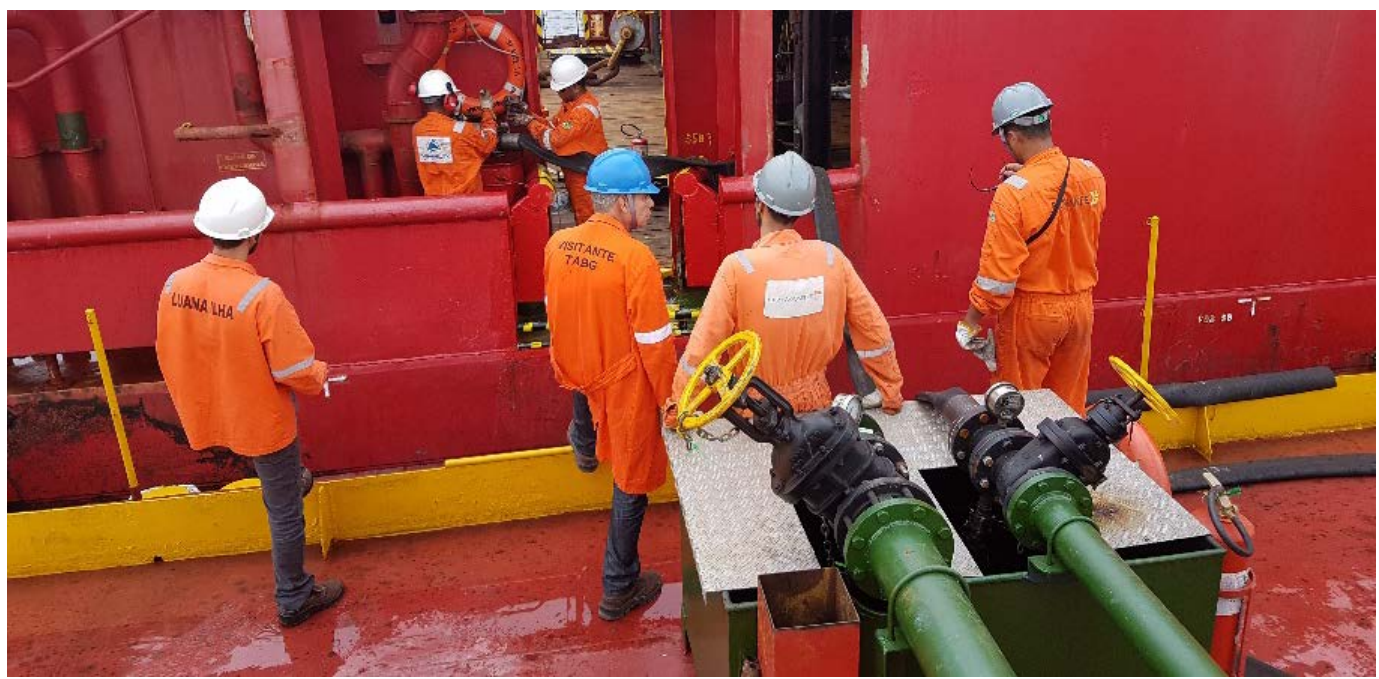

Figura 8 - Conexão de mangote entre barcaça e navio.

Fonte: A autora.

Através de um fluxômetro é possível acompanhar a vazão e o volume total abastecido, conforme Figura 9.

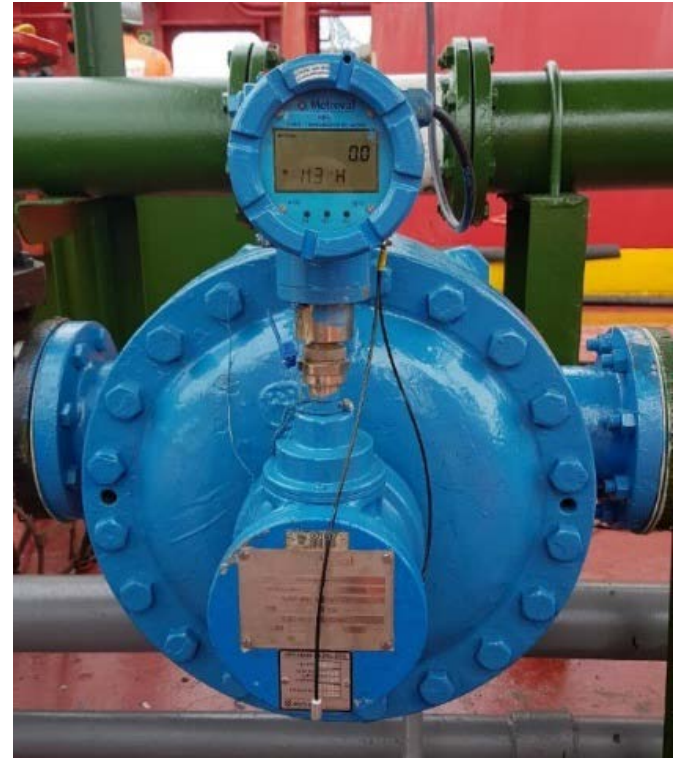

Figura 9 - Fluxômetro da barcaça.

Fonte: A autora.

A maioria das barcaças abastecedoras não são motorizadas e necessitam ser empurradas por rebocadores para se aproximar da embarcação a ser abastecida, conforme Figura 10. 


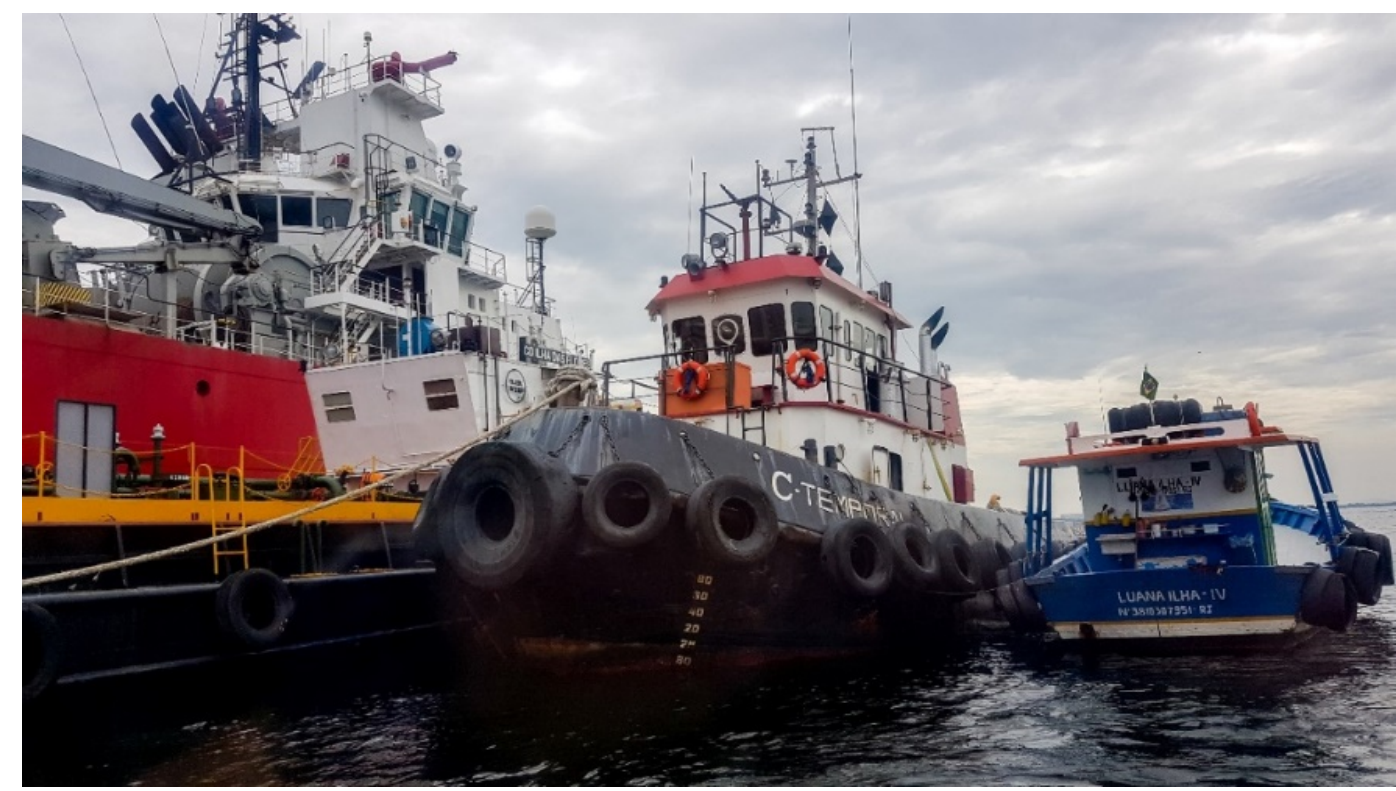

Figura 10 - Navio, barcaça, rebocador e barco de apoio durante operação de abastecimento.

Fonte: A autora.

Conforme mencionado, as barcaças carregam o bunker atracadas em píer, a partir dos mesmos tanques de terra e com trechos de duto em comum ao abastecimento por duto. Vale ressaltar que há um alcance maior na modalidade barge, permitindo que a barcaça abasteça navios operando em outros terminais no mesmo estado. Isso ocorre inclusive para portos distintos, de modo que constem portos atendidos por abastecimento via barcaça sem possuir abastecimento via duto.

As barcaças podem abastecer tanto os navios que se encontram atracados em píer, sendo atracadas a contrabordo (conforme ilustrado na Figura 11), quanto os navios que se encontram ancorados no fundeadouro do porto.

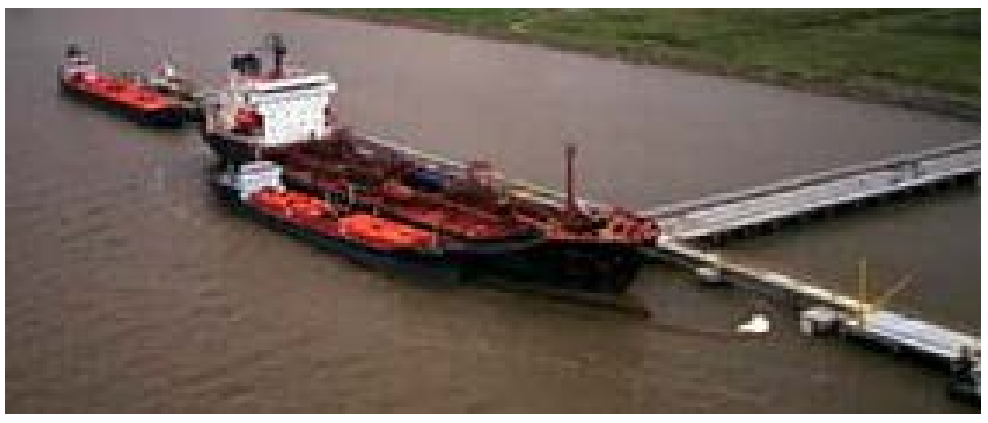

Figura 11 - Abastecimento com barcaça a contrabordo.

Fonte: Petrobras. 
Abastecimentos por barcaça a contrabordo oferecem a praticidade de abastecimento concomitante à operação para navios atracados em píer sem alinhamento de bunker. Alguns portos chegam a oferecer as duas modalidades (duto e barcaça a contrabordo), sendo a decisão de como será feito o abastecimento em função da posição de atracação do navio do píer.

O abastecimento em fundeio, por outro lado, pode representar flexibilidade para navios com pouca autonomia. Caso um navio precise acrescentar um ponto operacional à sua rota apenas para a realização de abastecimento, não necessariamente ele aguardará disponibilidade de píer. Caso ele se dirija a um porto habilitado para realização de abastecimentos no fundeio, ele poderá se dirigir diretamente ao fundeadouro, independente das operações ocorrendo no píer. A Figura 12 ilustra navios fundeados na Baía de Guanabara.

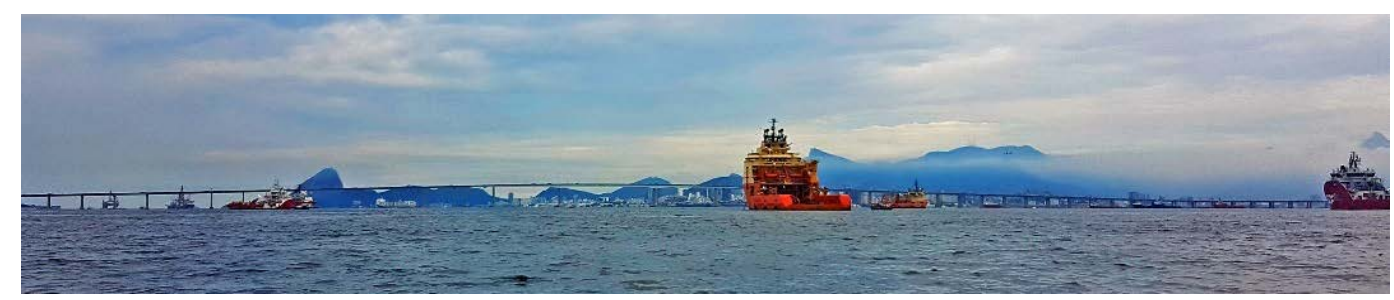

Figura 12 - Navios fundeados na Baía de Guanabara

Fonte: A autora.

Entretanto, outros fatores podem acarretar atrasos para o abastecimento em fundeio, como indisponibilidade da barcaça por fila de abastecimentos e inviabilidade de abastecimento devido às condições do tempo (vento e ondas). Em determinados momentos esse atraso pode ser grande o suficiente para justificar o custo de uma atracação no píer, porém nem sempre a informação do tempo total de espera será prevista com antecedência suficiente para se tomar a melhor decisão.

A Figura 13 resume as possibilidades de abastecimento, considerando as modalidades utilizadas e posição do navio a ser abastecido. 


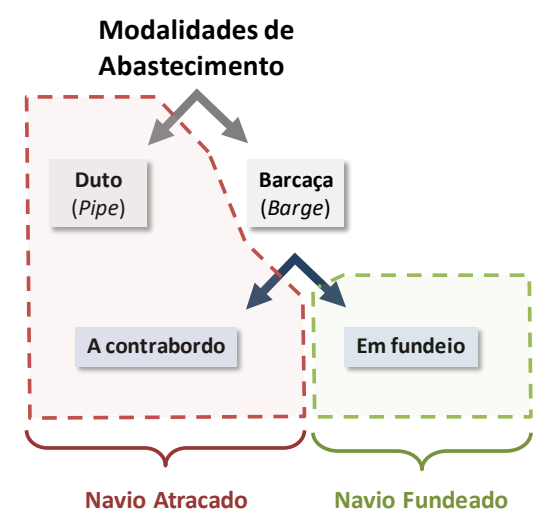

Figura 13 - Possibilidades de abastecimento e posição do navio correspondente.

Fonte: A autora.

A possibilidade de se realizar abastecimento por barcaça, seja a contrabordo ou no fundeio, depende das condições operacionais e ambientais do local de operação. Para aqueles pontos em que o abastecimento por barcaça é viável, a decisão de alocação de barcaças por porto é feita pela área de comercialização de bunker.

A próxima seção detalha os aspectos do fornecimento de bunker nacional que afetam as tomadas de decisão dos programadores e operadores da frota de cabotagem da Petrobras.

\subsection{1}

\section{Abastecimento da frota de cabotagem Petrobras}

Para um maior aproveitamento da utilização da frota TCP, a equipe da Logística deve buscar realizar abastecimentos de forma simultânea a operações de carga e descarga. Conforme mencionado anteriormente, isso é possível em píeres que dispõem de abastecimento por duto ou abastecimento por barcaça a contrabordo.

Nessas situações, os custos incrementais referentes ao abastecimento do navio são apenas aqueles referentes à movimentação do bunker pelo operador logístico e, quando aplicável, pela barcaça. Isso porque as despesas portuárias de entrada no porto, atracação e desatracação ocorreriam da mesma forma caso o navio atracasse apenas para carregar ou descarregar o produto, sem abastecer. 
Em situações em que o navio não possui autonomia para chegar a um porto de carga ou descarga que ofereça abastecimento simultâneo à operação, existem alternativas a princípio mais onerosas.

Caso a rota inclua operação em um porto habilitado para abastecimento, porém este porto disponha apenas de abastecimento via barcaça no fundeadouro, é possível realizar abastecimento antes ou após a operação. Nesse caso, como o navio permanece nos limites do porto, não há incidência adicional de taxas referente à entrada no porto - as taxas pagas para a operação permanecem válidas para a estadia do navio no fundeadouro. Há, todavia, aumento nos custos de praticagem, devido à existência de uma manobra adicional.

Por exemplo, caso o navio abasteça antes de atracar, em vez de seguir diretamente do fundeadouro fora de barra ao píer:

1. O navio é manobrado do fundeadouro externo ao fundeadouro interno, onde realiza o abastecimento;

2. Após o abastecimento, assim que houver píer disponível, o navio é manobrado do fundeadouro interno ao píer;

3. Ao final da operação o navio é manobrado para desatracar do píer e sair do porto.

Assim, são realizadas no total três manobras. A Figura 14 compara as manobras envolvidas em uma atracação sem fundeio com as manobras listadas para o exemplo mencionado.
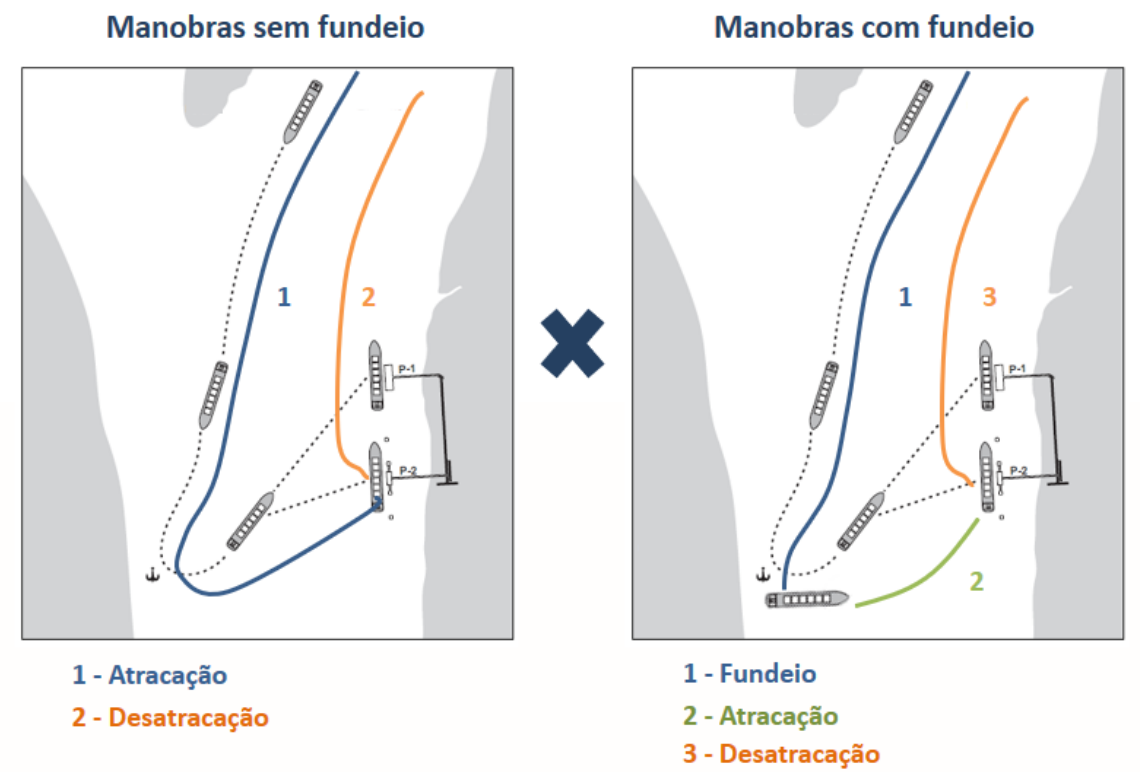

Figura 14 - Manobra adicional para fundeio.

Fonte: Adaptado de "Informações Portuárias Terminal Belém”, Transpetro. 
Vale ressaltar que, além do custo de manobra adicional, determinados portos possuem cobranças específicas para o fundeio. Também é possível se deparar em situações em que não há vagas no fundeadouro interno. Caso nenhum ponto da rota disponha de abastecimento, será necessário direcionar o navio a um porto adicional que permita abastecer o navio. Nessa situação, a primeira alternativa considerada é direcionar o navio a um porto localizado entre os pontos de origem e destino e habilitado para abastecimentos no fundeio. Um exemplo de inclusão de porto na rota pode ser visto na Figura 15.

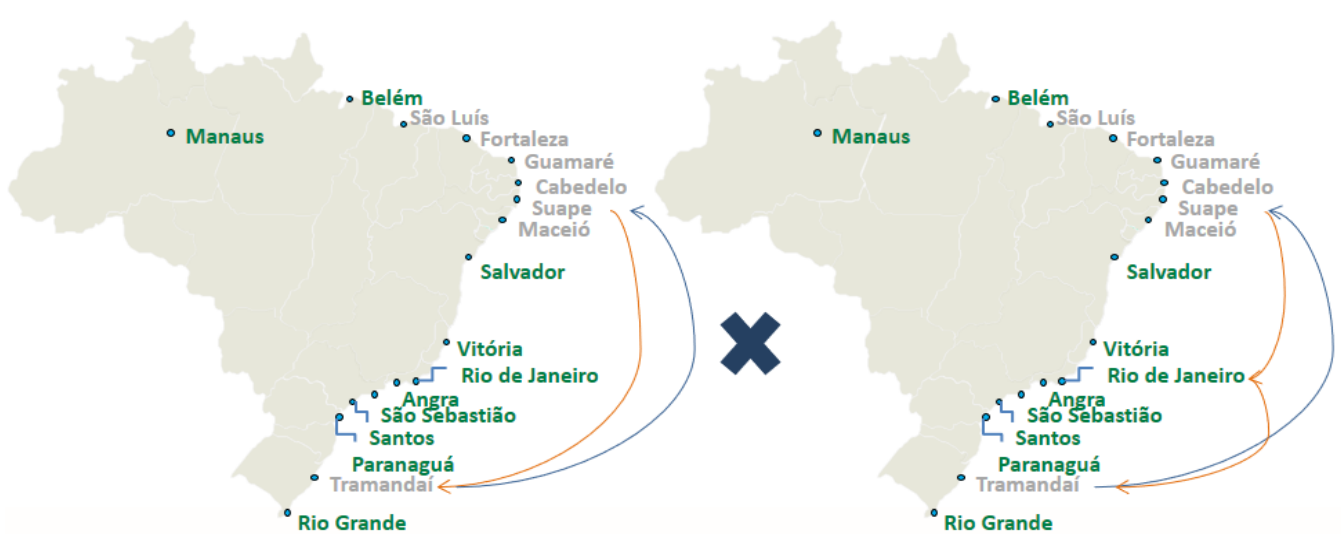

Figura 15 - Inclusão de porto para abastecimento na rota.

Fonte: A autora.

Para os abastecimentos realizados em portos distintos das operações de carga e descarga, os custos portuários são ainda maiores. Além da necessidade das manobras de entrada e saída do navio, outras despesas são geradas pela simples entrada do navio no porto: despesas de Livre Prática, TUF e FUNAPOL. Nesse caso, todos os custos da escala adicional são atribuíveis ao abastecimento. O tempo adicional de viagem quando comparado ao trecho teórico sem abastecimento também reflete um custo aplicável, referente ao proporcional do aluguel do navio ao atraso no transporte.

Caso não haja portos com abastecimento disponível entre a origem e o destino da carga transportada, será necessário desviar o navio de sua rota para chegar a um porto habilitado para abastecimento. Esse cenário, exemplificado esquematicamente na Figura 16, envolve inclusive consumo de combustível adicional para poder posicionar o navio no ponto de abastecimento. 


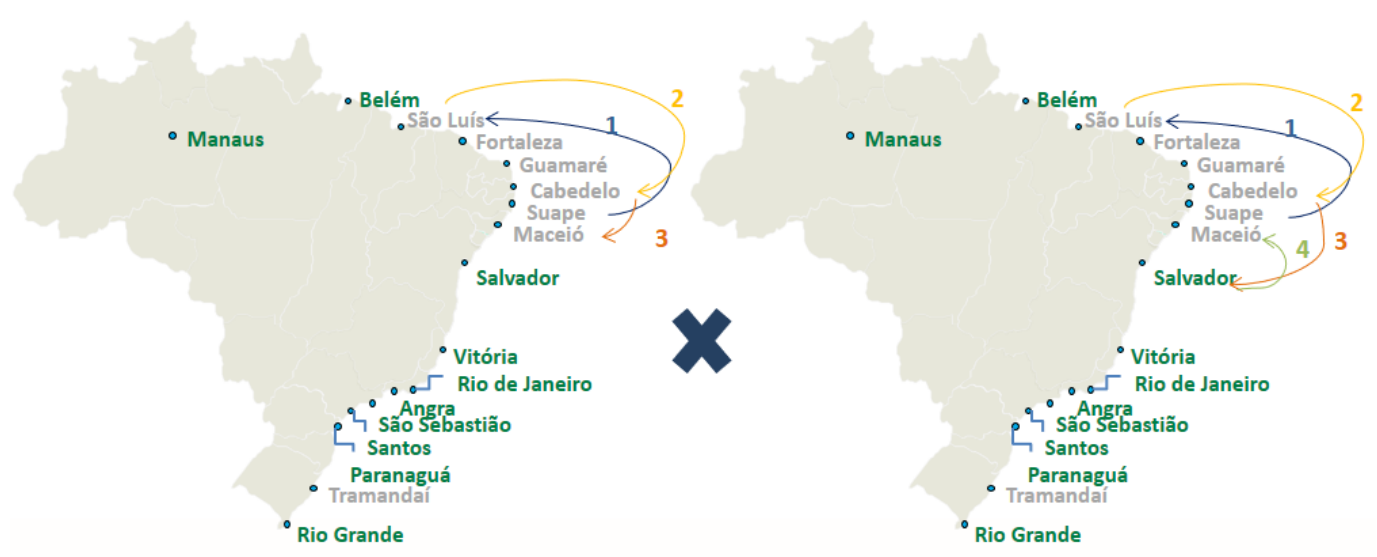

Figura 16 - Inclusão de porto com desvio de rota para abastecimento.

Fonte: A autora.

Dependendo do trecho de navegação adicional e a existência de portos habilitados para abastecimento entre origem e destino, pode ser mais econômico atracar o navio para abastecer sem desviá-lo da rota. Essa economicidade depende do custo de desvio (referente ao aluguel do navio e consumo adicional de combustível) e dos custos portuários de cada porto considerado.

Com a intenção de detalhar as especificidades operacionais que restringem as decisões de onde abastecer, a próxima seção detalha a disponibilidade de abastecimento nos terminais do país.

\subsection{2}

\section{Disponibilidade de abastecimento por terminal}

No ano de 2017 apenas 14 dos 24 portos nacionais ofereceram abastecimento. Os portos com abastecimento disponível e a União Federativa em que se encontram estão listados na Tabela 9. 
Tabela 9 - Portos com abastecimento disponível em 2017.

\begin{tabular}{ll}
\hline Porto & UF \\
\hline MANAUS & AM \\
BELEM & PA \\
VILA DO CONDE & PA \\
FORTALEZA & CE \\
SALVADOR & BA \\
ARATU & BA \\
TUBARAO & ES \\
VITORIA & ES \\
RIO DE JANEIRO & RJ \\
ANGRA DOS REIS & RJ \\
SAO SEBASTIAO & SP \\
SANTOS & SP \\
PARANAGUA & PR \\
RIO GRANDE & RS \\
\hline
\end{tabular}

Fonte: A autora.

Durante o ano de 2017, o abastecimento por duto só esteve disponível em onze portos: Manaus, Belém, Fortaleza, Salvador, Tubarão, Rio de Janeiro, Angra dos Reis, São Sebastião, Santos, Paranaguá e Rio Grande. Cabe ressaltar que cinco desses terminais se encontram na região Sudeste do país, cuja costa corresponde a 22\% da extensão do litoral brasileiro. A Figura 17 ilustra a localização dos portos com abastecimento por duto disponível.

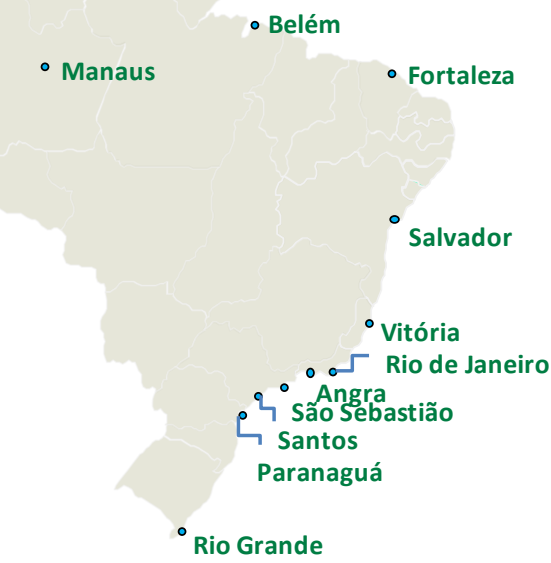

Figura 17 - Portos com abastecimento por duto disponível em 2017.

Fonte: A autora.

O porto de Fortaleza, entretanto, deve ser tratado com ressalvas. Dado o processamento de petróleos naftênicos na refinaria local (LUBNOR), o teor de acidez do bunker é superior ao restante da produção nacional. Apesar de não se 
tratar de um produto desenquadrado, dada a própria ressalva da ANP para óleos provenientes de petróleos naftênicos, o produto é rejeitado por grande parte dos armadores de navios, de modo que apenas parte da frota usufrui de abastecimentos nesse ponto.

Em sete dos onze portos a operação de navios de terceiros é muito rara ou mesmo nula. Nos portos públicos de Belém, Santos, Paranaguá e Rio Grande a atracação de navios de terceiros nos píeres habilitados para abastecimento por duto já ocorre com alguma frequência.

O abastecimento de barcaça a contrabordo é possível em Belém, Vila do Conde, Tubarão, Vila Velha, Rio de Janeiro (apenas em alguns terminais), Santos, Paranaguá e Rio Grande. Dada a proximidade geográfica, a mesma barcaça atende os portos de Belém e Vila do Conde. O mesmo também é válido para Tubarão e Vila Velha. O produto utilizado para abastecimentos a contrabordo em Vila do Conde, inclusive da frota de cabotagem de derivados escuros, é carregado pela barcaça dos tanques de terra de Belém. De maneira semelhante os abastecimentos de Vila Velha são feitos com produto outrora armazenado em Tubarão.

Dos terminais em que o abastecimento por duto também está disponível, o único que prioriza o abastecimento por barcaça a contrabordo com uma certa frequência é o de Santos, nas ocasiões em que o posicionamento do navio no píer inviabiliza o abastecimento por duto. O abastecimento a contrabordo também é importante para a frota de lubrificantes, que opera em terminais de terceiros sem estrutura para abastecimento por duto nos portos de Santos e no Rio de Janeiro. Nos terminais da Transpetro da Baía de Guanabara (Ilha d’Água e Ilha Redonda), local no Rio de Janeiro onde operam os navios de petróleo, GLP e derivados claros e escuros, não é possível realizar abastecimento a contrabordo - apenas por duto, ou no fundeadouro interno da baía.

O abastecimento no fundeio está disponível em Belém, Vila do Conde, Salvador, Aratu, Rio de Janeiro, Paranaguá e Rio Grande. As áreas de fundeio que atendem o porto de Aratu são as próprias áreas de fundeio de Salvador, na Baía de Todos os Santos. É importante, entretanto, sinalizar que navios da Petrobras que operam em Aratu podem abastecer imediatamente antes ou após a operação sem custo de desvio de rota ou novos custos de entrada em porto. Todavia, isso implica um pior aproveitamento da embarcação, uma vez que o navio precisará se posicionar no fundeadouro, aguardar condições de tempo favoráveis, a 
disponibilidade da barcaça e a duração do abastecimento em si, para somente em seguida prosseguir com o transporte.

A Tabela 10 resume as modalidades de abastecimento disponíveis em cada porto habilitado para o suprimento de bunker, detalhando o posicionamento da embarcação a ser abastecida para cada modalidade disponível.

Tabela 10 - Disponibilidade de Abastecimento por Porto.

\begin{tabular}{|c|c|c|c|c|}
\hline \multirow[b]{2}{*}{ Porto } & \multirow[b]{2}{*}{ UF } & \multirow{2}{*}{$\begin{array}{l}\text { Duto } \\
\text { Duto }\end{array}$} & \multicolumn{2}{|c|}{ Barcaça } \\
\hline & & & Contrabordo & Fundeio \\
\hline MANAUS & AM & $X$ & & \\
\hline BELEM & PA & $x$ & $x$ & $x$ \\
\hline VILA DO CONDE & PA & & $x$ & $x$ \\
\hline FORTALEZA & CE & $x$ & & \\
\hline SALVADOR & BA & $x$ & & $x$ \\
\hline ARATU & BA & & & $x$ \\
\hline TUBARAO & ES & $x$ & $x$ & \\
\hline VITORIA & ES & & $\mathrm{X}$ & \\
\hline RIO DE JANEIRO & RJ & $x$ & $x$ & $x$ \\
\hline ANGRA DOS REIS & RJ & $x$ & & \\
\hline SAO SEBASTIAO & SP & $x$ & & \\
\hline SANTOS & SP & $x$ & $x$ & \\
\hline PARANAGUA & PR & $x$ & $x$ & $x$ \\
\hline RIO GRANDE & RS & $x$ & $x$ & $X$ \\
\hline \multicolumn{2}{|c|}{ Posição do navio } & \multicolumn{2}{|c|}{ Atracado } & Fundeado \\
\hline
\end{tabular}

Fonte: A autora.

A próxima seção detalha como é feito o fornecimento de bunker para cada um desses portos, diferenciando os que recebem produto das refinarias por modal dutoviário daqueles que dependem de transferência por outros modais.

\subsection{3}

\section{Suprimento de bunker}

Conforme descrito na seção 3.4.1, para alguns dos terminais com abastecimento disponível, o bunker armazenado em tanque de terra é recebido por duto conectando a tancagem de uma refinaria ao parque de tanques do terminal. Para outros, entretanto, é necessário transportar o bunker por cabotagem a partir de um outro terminal aquaviário. Nesses casos, navios de óleo combustível atracam em um terminal conectado a uma refinaria, carregam bunker em seus tanques de carga (podendo inclusive abastecer seus tanques de combustível na 
mesma ocasião) e transferem esse produto a outros terminais, permitindo que os lotes produzidos pelas refinarias atendam o mercado de todo o país. As principais rotas de cabotagem de bunker de 2017 estão exemplificadas na Figura 18.

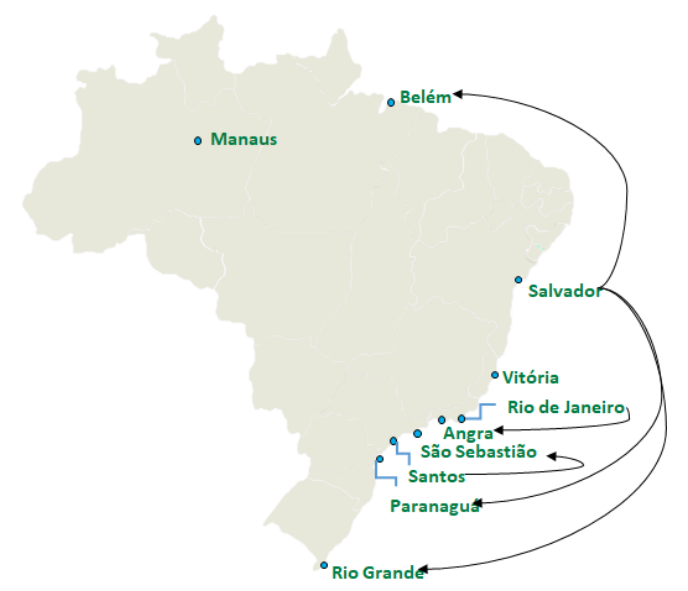

Figura 18 - Exemplos de rotas de cabotagem de bunker.

Fonte: A autora.

Dos quatorze portos com abastecimento disponível apenas cinco recebem todo o bunker demandado por duto da refinaria mais próxima. São eles: Manaus, Fortaleza, Salvador, Rio de Janeiro e Santos.

O porto de Belém não é conectado a nenhuma refinaria do sistema, sendo o polo inteiramente dependente de transporte marítimo para atender seus mercados, inclusive de bunker.

O porto de Tubarão é atendido pelo óleo combustível produzido na REGAP, em Minas Gerais, que é transferido até o Espírito Santo por ferrovia. Entretanto, a depender da demanda por óleo combustível da Usina Termelétrica de Viana, pode ser necessário complementar o mercado de bunker com produto de outras refinarias por cabotagem.

Em Angra dos Reis e São Sebastião, portos importantes na internação de petróleo para as refinarias, não há dutos para transporte de bunker entre as refinarias mais próximas e os terminais, devendo todo o MF ser recebido de navio. Em Paranaguá é possível receber produção de bunker da REPAR por duto, mas usualmente é necessário complementar a produção com produto de outras refinarias por cabotagem para garantir o atendimento do mercado. Já em Rio Grande a refinaria mais próxima (REFAP) não produz MF, sendo também esse mercado dependente de produto de cabotagem. Vila do Conde, Aratu e Vila Velha 
sequer possuem tancagem de bunker e são atendidos por barcaças que carregam em outros portos.

A Tabela 11 resume a origem do bunker para cada porto com abastecimento disponível, diferenciando os dependentes de cabotagem e transporte ferroviário daqueles que contam com produção local (refinaria conectada por duto). A tabela também detalha os portos que não possuem tancagem de bunker e compartilham barcaças abastecedoras com portos adjacentes.

Tabela 11 - Origem do bunker por porto.

\begin{tabular}{lccccc}
\hline Porto & UF & Produção local & Cabotagem & Ferrovia & Porto adjacente \\
\hline MANAUS & AM & $X$ & & & \\
BELEM & PA & & $X$ & & \\
VILA DO CONDE & PA & & & & \\
FORTALEZA & CE & $X$ & & & \\
SALVADOR & BA & $X$ & & $X$ & $X$ \\
ARATU & BA & & & & \\
TUBARAO & ES & & & \\
VITORIA & ES & & & & \\
RIO DE JANEIRO & RJ & $X$ & & \\
ANGRA DOS REIS & RJ & & $X$ & \\
SAO SEBASTIAO & SP & & $X$ & \\
SANTOS & SP & $X$ & & & \\
PARANAGUA & PR & $X$ & $X$ & \\
RIO GRANDE & RS & & $X$ & & \\
\hline
\end{tabular}

Fonte: A autora.

A próxima seção trata daqueles portos que não estiveram disponíveis para realização de abastecimento no ano de 2017, verificando quais podem ser considerados potenciais para abastecimentos futuros.

\subsection{4}

\section{Pontos potenciais para abastecimento}

Conforme ressaltado na introdução dessa dissertação, nas quarenta e uma plataformas e oito monoboias do país, o abastecimento de navios é inviável pela própria estrutura operacional. Já dos 24 portos em que a Petrobras operou em 2017, apenas 14 estavam disponíveis para abastecimentos. Os dez portos restantes devem ser avaliados para a realização de abastecimentos no futuro. 
A Tabela 12 resumiu a viabilidade de abastecimento por terminal para os 24 portos, e oito monoboias em que a Petrobras operou em 2017. As plataformas foram omitidas da tabela, porém podem ser observadas na listagem completa disponível no Apêndice 1.

Vale ressaltar que dos dez portos considerados potenciais, três já dispuseram de abastecimentos no passado. O porto de Itacoatiara, também no Amazonas, já recebeu abastecimentos quando havia barcaças alocadas à região. Nesse caso as barcaças carregavam bunker em Manaus e abasteciam navios a contrabordo em Itacoatiara, de modo semelhante ao que ocorre hoje em Vila do Conde e Vila Velha.

Já em São Luís, existe tanque de terra e alinhamento que permite realizar abastecimentos em alguns píeres. Entretanto, como o tanque de terra é utilizado para armazenamento de OCCMB - Óleo Combustível com Controle de Metais e Baixo Enxofre, produto destinado às usinas termelétricas - em períodos de alta demanda das térmicas é desaconselhado entregar bunker para evitar risco de falhas de energia na região. Em 2018, entretanto, já foram retomadas as entregas de bunker nesse local. O produto utilizado para esse atendimento é integralmente oriundo de cabotagem da Bahia.

Por fim, o porto de Suape apresenta situação similar ao de São Luís, uma vez que os tanques outrora utilizados para bunker hoje são de dedicação exclusiva ao atendimento das usinas termelétricas próximas. Esses tanques, assim como em São Luís, recebem por navio Óleo Combustível produzido na Bahia. Estão sendo avaliados, entretanto, investimentos para se conectar a tancagem de escuros da RNEST ao píer, permitindo que se realizem abastecimentos sem dependência de cabotagem. Os investimentos também permitiriam usar a produção da RNEST para atendimento do mercado de térmicas, gerando economias no transporte marítimo de óleo combustível. 
Tabela 12 - Viabilidade de abastecimento por terminal.

\begin{tabular}{|c|c|c|c|c|}
\hline Porto & UF & Disponível & Potencial & Inviável \\
\hline COARI & AM & & $x$ & \\
\hline MANAUS & AM & $x$ & & \\
\hline ITACOATIARA & AM & & $x$ & \\
\hline BELEM & PA & $x$ & & \\
\hline VILA DO CONDE & PA & $x$ & & \\
\hline SAO LUIS & MA & & $x$ & \\
\hline FORTALEZA & CE & $x$ & & \\
\hline PECEM & CE & & $x$ & \\
\hline GUAMARÉ & $\mathrm{RN}$ & & & $x$ \\
\hline CABEDELO & PB & & $x$ & \\
\hline SUAPE & PE & & $x$ & \\
\hline MACEIO & $A L$ & & $x$ & \\
\hline ARACAJU & SE & & & $x$ \\
\hline SALVADOR & $\mathrm{BA}$ & $x$ & & \\
\hline ARATU & BA & $x$ & & \\
\hline NORTE CAPIXABA & ES & & & $x$ \\
\hline BARRA DO RIACHO & ES & & $x$ & \\
\hline TUBARAO & ES & $x$ & & \\
\hline VITORIA & ES & $x$ & & \\
\hline BOIAS BACIA DE CAMPOS & RJ & & & $x$ \\
\hline MONOBOIA PRA-1 & RJ & & & $x$ \\
\hline PORTO DO AÇU & RJ & & $x$ & \\
\hline RIO DE JANEIRO & RJ & $x$ & & \\
\hline ANGRA DOS REIS & RJ & $x$ & & \\
\hline SAO SEBASTIAO & SP & $x$ & & \\
\hline SANTOS & SP & $x$ & & \\
\hline BOIA BACIA DE SANTOS & SP & & & $x$ \\
\hline PARANAGUA & PR & $x$ & & \\
\hline SÃO FRANCISCO DO SUL & SC & & & $x$ \\
\hline TRAMANDAÍ & RS & & & $x$ \\
\hline PORTO ALEGRE & RS & & $x$ & \\
\hline \multirow[t]{2}{*}{ RIO GRANDE } & RS & $x$ & & \\
\hline & Total & 14 & 10 & 8 \\
\hline
\end{tabular}

Fonte: A autora.

Os demais sete portos não possuem estrutura para abastecimentos, podendo ser avaliados como potenciais novos pontos. A próxima seção explicita a aplicação do modelo de custos e os resultados observados. 


\section{2}

\section{Modelo de custos}

O Capítulo 3 descreveu a metodologia utilizada para modelar os custos de abastecimentos da Petrobras. Nesta seção são apresentados os resultados observados ao longo da aplicação do modelo.

Para estimar os custos variáveis de cada ponto foi necessário calcular o item de custo de "Movimentação de Produto", que engloba para determinados casos o transporte marítimo. A Figura 19 exemplifica o cálculo do custo do transporte de 20.000 toneladas de bunker de Santos até Angra dos Reis, considerando reposição do navio no Rio de Janeiro para a viagem seguinte. Os valores foram multiplicados por um fator de forma a não revelar os dados da companhia.

\begin{tabular}{|l|r|}
\hline Operação Santos: & $\mathrm{R} \$ 248.387$ \\
\hline Viagem Santos - Angra: & $\mathrm{R} \$ 44.458$ \\
\hline Operação Angra: & $\mathrm{R} \$ 307.986$ \\
\hline Viagem Angra - Rio: & $\mathrm{R} \$ 30.231$ \\
\hline \\
Custo Total & $\mathrm{R} \$ 631.061$ \\
Volume Total & 20.000 \\
Custo/ton & $\mathrm{R} \$ 31,55$
\end{tabular}

Figura 19 - Exemplo de cálculo de custo de cabotagem de bunker.

Fonte: a autora.

As rotas de cabotagem de bunker foram agrupadas por destino a fim de se determinar o custo médio de transporte de bunker do local. A Figura 20 exemplifica os cálculos de custo médio de cabotagem por porto de destino - no exemplo para Angra dos Reis e São Sebastião, novamente com dados multiplicados por um fator.

$\begin{array}{cr}\text { Angra dos Reis } & \text { Custo /ton } \\ \text { Viagem } 1 & \mathrm{R} \$ 31,55 \\ \text { Viagem } 2 & \mathrm{R} \$ 31,08 \\ \text { Viagem } 3 & \mathrm{R} \$ 26,38 \\ \text { Viagem } 4 & \mathrm{R} \$ 29,18 \\ \text { Média } & \mathbf{R} \mathbf{2 9 , 5 5}\end{array}$

$\begin{array}{cr}\text { São Sebastião } & \text { Custo /ton } \\ \text { Viagem 1 } & \mathrm{R} \$ 54,49 \\ \text { Viagem 2 } & \mathrm{R} \$ 27,45 \\ \text { Viagem 3 } & \mathrm{R} \$ 29,18 \\ \text { Viagem 4 } & \mathrm{R} \$ 29,80 \\ \text { Viagem 5 } & \mathrm{R} \$ 27,57 \\ \text { Média } & \mathbf{R} \$ 33,70\end{array}$

Figura 20 - Exemplo de cálculo de custo médio de cabotagem por destino. 
Após a estimativa de cada item de custo foi possível observar as nuances entre cada porto com abastecimento disponível. A Figura 21 ilustra a representatividade de cada item de custo por porto para o exemplo de um abastecimento de 1.000 toneladas de bunker em um navio de porte de 40.000 toneladas na situação de abastecimento "Fundeio exclusivo", em que o navio dá entrada no fundeadouro de um porto apenas para abastecer.

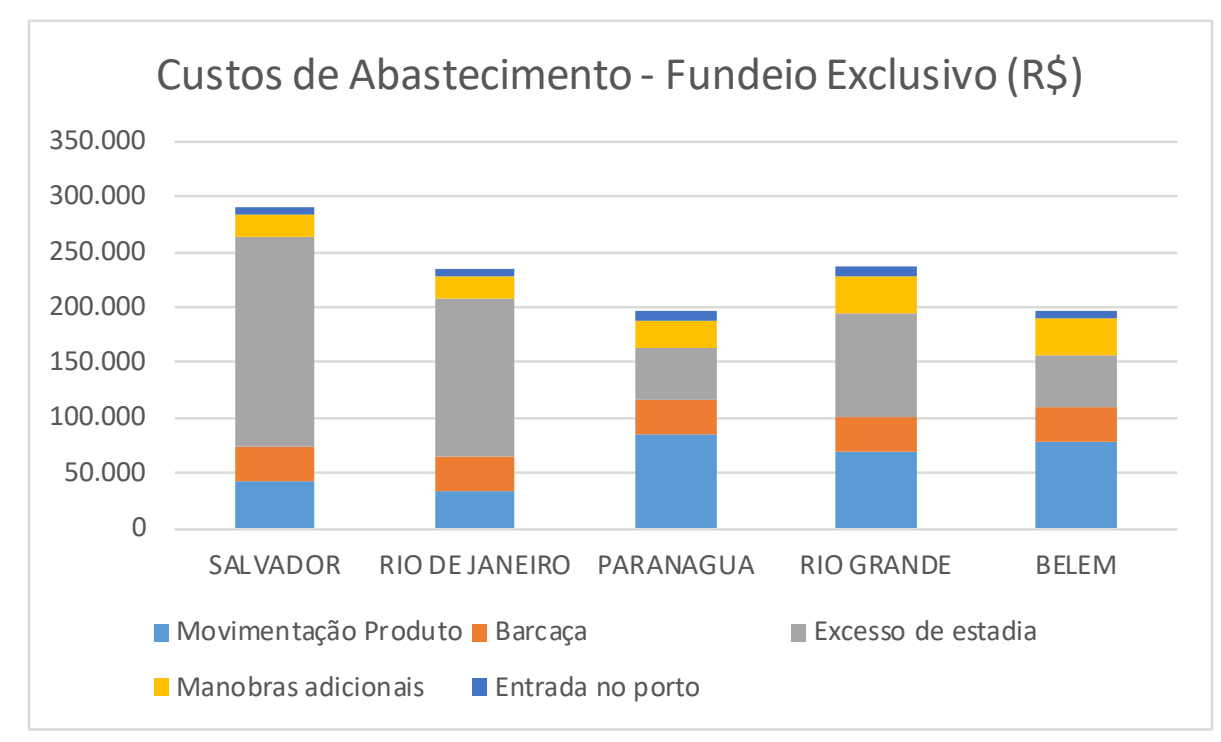

Figura 21 - Custos de Abastecimento na situação "Fundeio Exclusivo".

Fonte: A autora.

À exceção do item “Barcaça”, que adotou para todos os portos um valor médio dos contratos COA, foi possível observar grandes variações de custos entre os portos com abastecimento disponível. A maior variação observada foi no item "Excesso de estadia”, que usou como base o tempo histórico de um navio na fila de abastecimentos de um fundeadouro. Para estadias superiores a um dia, este item de custo se torna o mais relevante de todo abastecimento, como observado para os portos de Salvador (média histórica de quatro dias de estadia), Rio de Janeiro (três dias) e Rio Grande (dois dias). Vale ressaltar que, em momentos mais conturbados, os portos de Paranaguá e Belém podem representar atraso superior ao histórico e também ter a parcela de estadia como a mais relevante dos custos de abastecimento.

Os custos portuários e de movimentação de produto também possuíram variações relevantes. A Figura 22 ilustra o custo de movimentação de produto de cada porto, para o mesmo porte de navio e mesmo volume abastecido anteriores. 
Nos pontos onde o abastecimento por duto é indisponível, também está sinalizado o custo da barcaça.

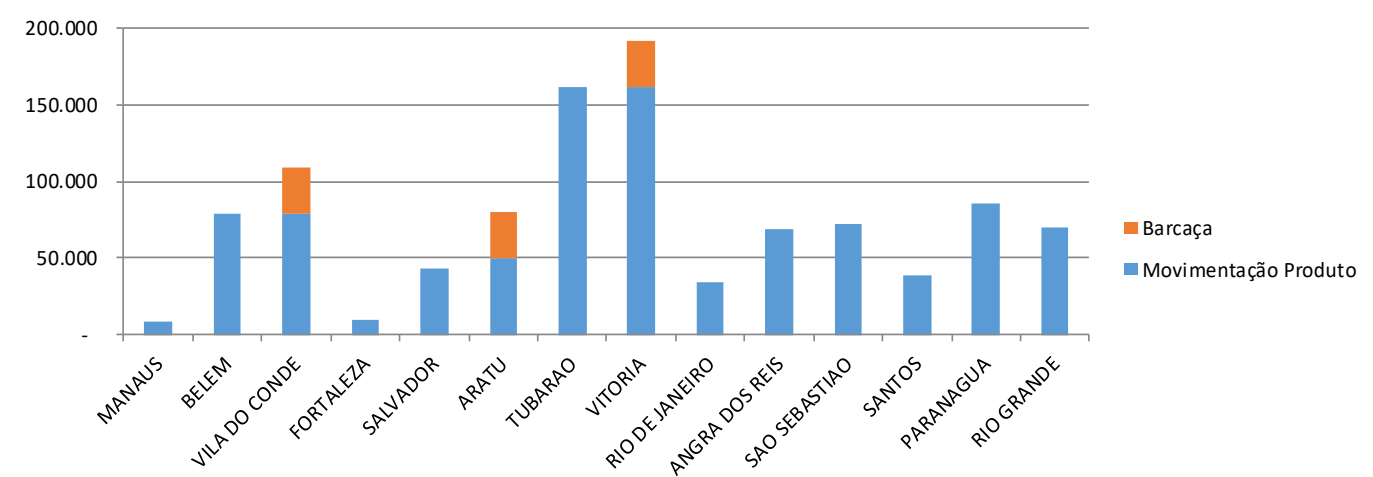

Figura 22 - Custos de Movimentação de Produto por Porto.

Fonte: A autora.

Ainda para o mesmo porte de embarcação, a Figura 23 traz os custos portuários aplicáveis para cada terminal, considerando uma entrada no porto exclusivamente para abastecer.

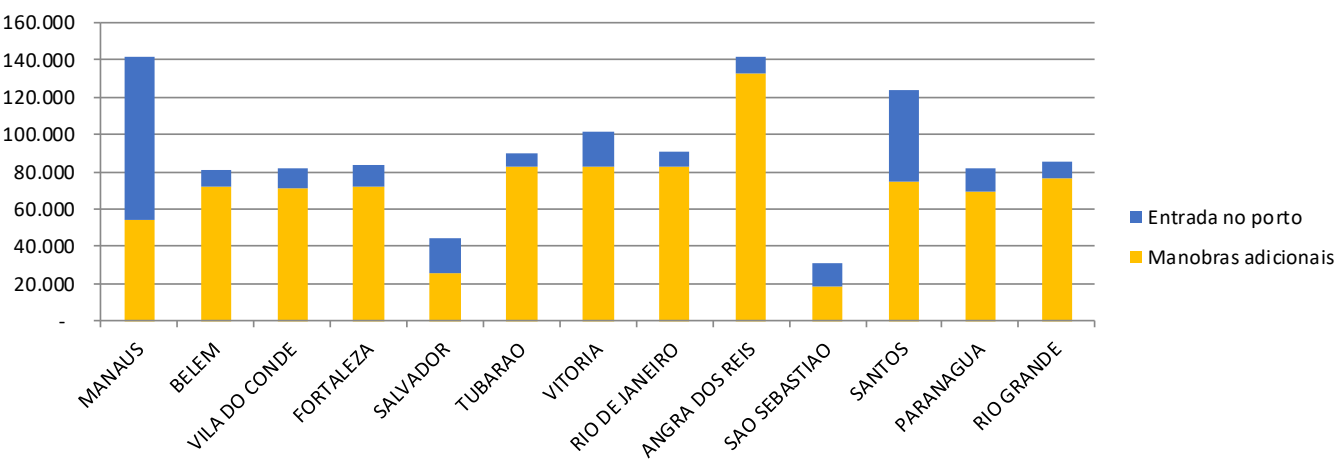

Figura 23 - Custos Portuários por Terminal.

Fonte: A autora.

Os custos de entrada no porto de Manaus são muito superiores que os demais dada a necessidade de praticagem para navegação no Rio Amazonas. Os portos de Salvador e São Sebastião possuem custos de manobra mais econômicos por possuírem rebocadores TCP, sem variação de custo por número de manobras realizadas.

Todavia, esses itens de custos podem não ser alocados à atividade de abastecimento caso ela ocorra simultaneamente a uma operação de carga ou descarga de produto. Assim, com o objetivo de apoiar as decisões de abastecimento, o modelo de custos se desdobrou em uma ferramenta capaz de 
identificar que itens de custos são aplicáveis a uma dada operação de abastecimento.

\section{3}

\section{Ferramenta de apoio à decisão}

Para um cenário hipotético de um navio saindo de Guamaré com destino Rio de Janeiro, existem diversas possibilidades de abastecimento. Caso possua autonomia, o navio pode seguir diretamente para o Rio de Janeiro e abastecer junto à sua operação no destino. Como alternativa, é possível parar o navio em Tubarão e atracá-lo no píer para abastecer. A Figura 24 compara os dois cenários mencionados.

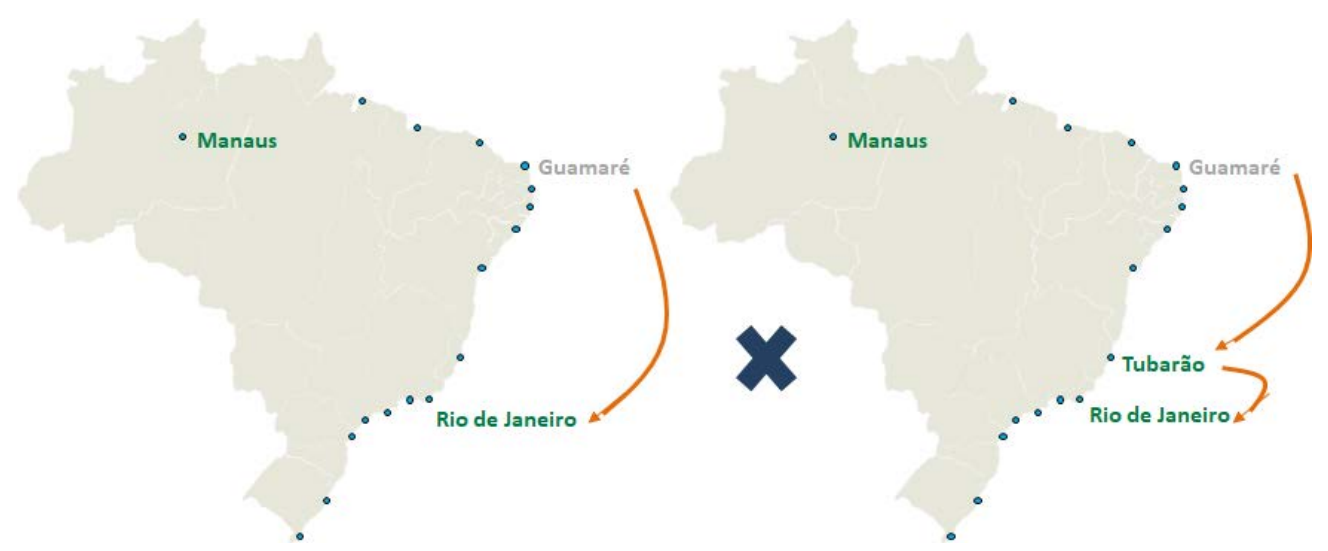

Figura 24 - Exemplo de abastecimentos entre Guamaré e Rio de Janeiro.

Fonte: A autora.

Caso se deseje avaliar os custos incidentes em cada uma das situações, é possível utilizar o simulador para o abastecimento em questão. As Figuras 25 e 26 ilustram respostas do simulador para um abastecimento de 800 toneladas de bunker para um navio de porte de 40.000 toneladas numa rota iniciada em Guamaré e finalizada no Rio de Janeiro, alternando apenas o porto onde o abastecimento seria realizado, entre Rio de Janeiro e Tubarão. 


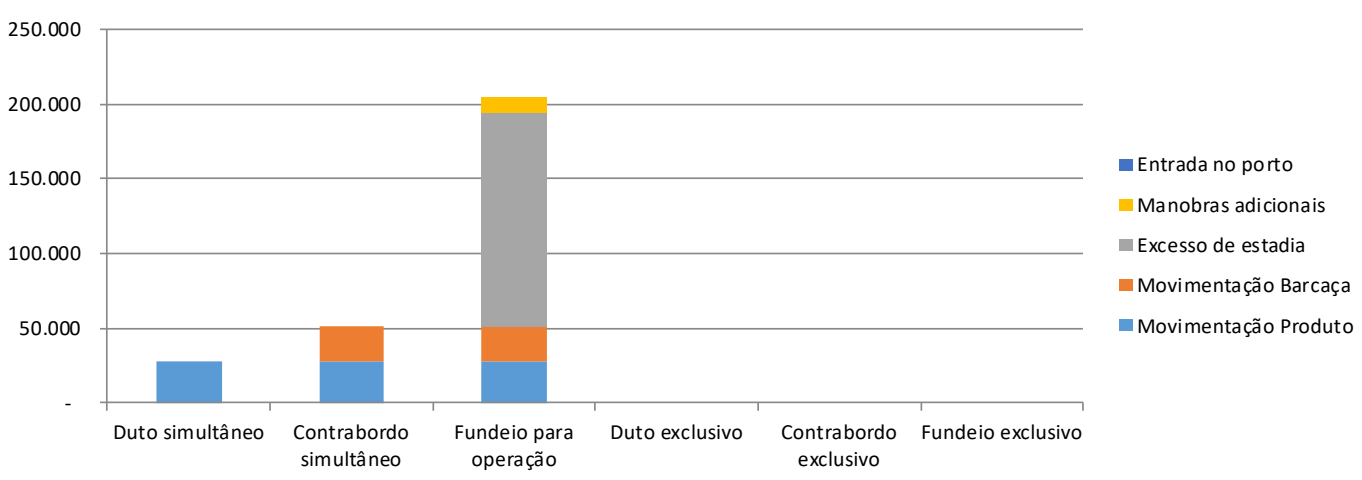

Figura 25 - Custos de abastecimento em Rio de Janeiro na rota Guamaré - Rio de Janeiro.

Fonte: A autora.

O simulador entende que a escala no porto de Tubarão seria exclusiva para abastecimento, portanto as situações de "Duto simultâneo", “Contrabordo simultâneo” e “Fundeio para operação” não são aplicáveis. Além disso, a situação "Fundeio exclusivo" não é viável no porto de Tubarão, sendo igualmente descartada. Para as situações “Duto exclusivo” e "Contrabordo exclusivo” são estimados os custos, segmentados em cada classificação.

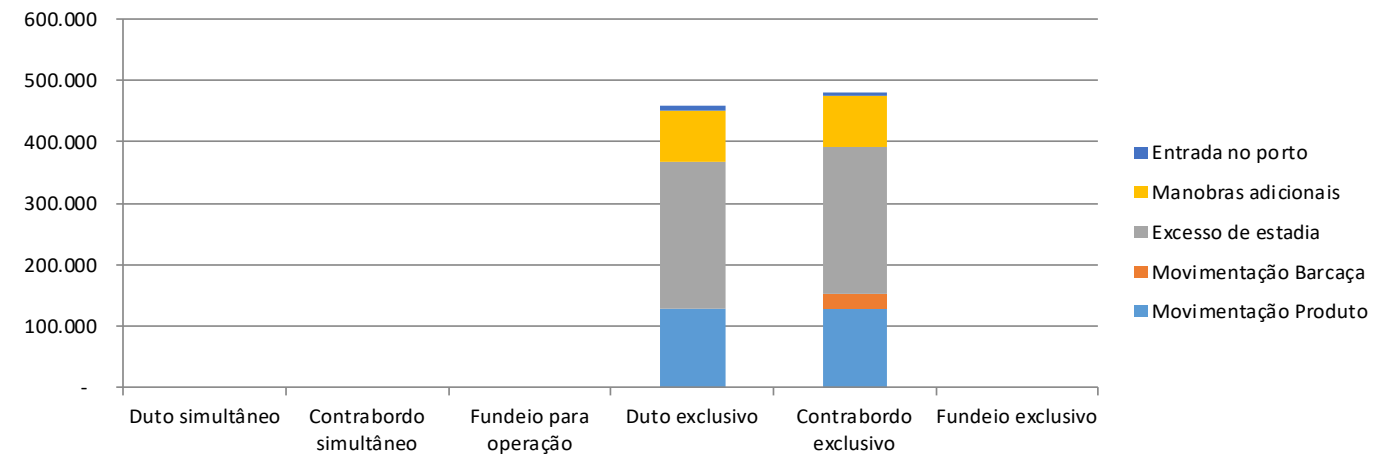

Figura 26 - Custos de abastecimento em Tubarão na rota Guamaré - Rio de Janeiro.

Fonte: A autora.

De maneira semelhante, o simulador entende que o porto do Rio de Janeiro faz parte da rota e portanto as situações "Duto exclusivo”, "Contrabordo exclusivo" e "Fundeio exclusivo" são descartadas. Para as situações "Duto simultâneo”, “Contrabordo simultâneo” e "Fundeio para operação” são estimados os custos, segmentados em cada classificação.

Já a ferramenta de apoio à decisão é capaz de listar, para um determinado par origem - destino, todas as situações de abastecimento aplicáveis em cada porto abastecedor e elencar os custos do menor ao maior. Um exemplo de situações de abastecimentos organizadas do menor ao maior custo para um abastecimento de 
800 toneladas de bunker em um navio de porte de 40.000 toneladas na rota Rio de Janeiro - Salvador pode ser vista na Figura 27.

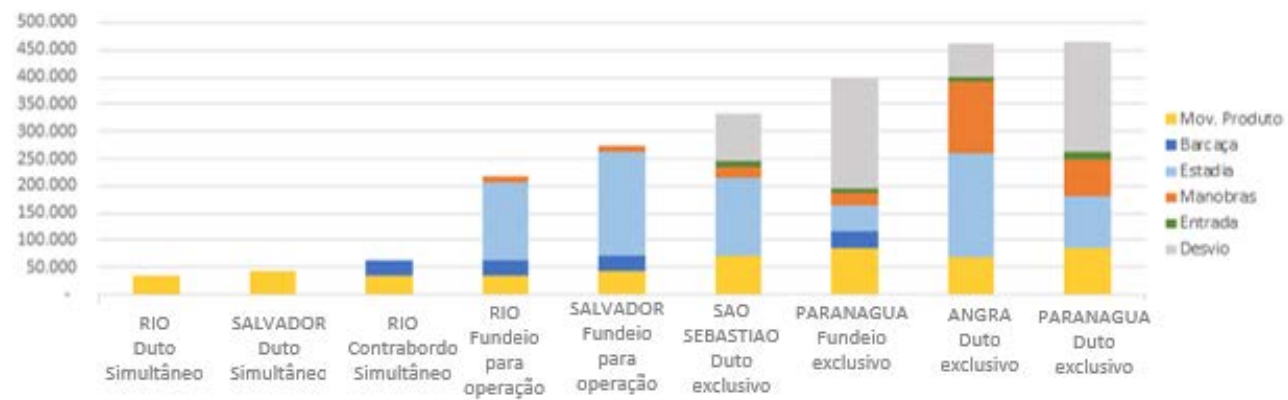

Figura 27 - Situações de abastecimento elencadas por custo.

Fonte: A autora.

Esta ferramenta pode ser usada pela equipe de operação de navios para auxiliar a tomada de decisão de onde abastecer, especialmente em casos em que a origem e o destino não oferecem possibilidade de abastecimento. Assim, é possível contemplar de uma só vez todos os custos associados.

A ferramenta também explicita o impacto da diária dos navios na operação. Uma alteração nos parâmetros representando uma maior estadia no fundeio do que a estadia no píer pode justificar a atracação de um navio apenas para abastecer, principalmente em portos com custos portuários reduzidos. Vale ressaltar que o porte do navio a ser abastecido tem grande impacto na resposta.

Entretanto, caso o navio possa abastecer de forma concomitante à operação, os custos portuários e de estadia serão atribuídos à atividade de transporte e não ao abastecimento. Nesses casos, o impacto é exclusivamente o custo variável, ressaltando a importância de abastecer a frota em terminais próximos a refinarias e que não dependem de outros modais além do dutoviário para disponibilizar o MF.

De fato, após levantar detalhadamente os custos variáveis e fixos referentes a uma operação de abastecimento, é comprovado o impacto que o excesso de estadia de uma embarcação ocasionado pelo abastecimento tem sobre o custo total da operação. Assumindo um volume de abastecimento de 2.000 toneladas de bunker, temos a parcela variável dos custos oscilando entre $\mathrm{R} \$ 17.000$ e $\mathrm{R} \$ 380.000$ por operação, a depender do porto em que o abastecimento será realizado. 
Apesar da variação de 2000\% nos custos ser considerável, o incremento de R\$363.000 é equiparável a um valor de duas a três diárias de navio dos maiores portes utilizados na cabotagem, indicando que o atraso no transporte ocasionado pela necessidade de abastecer rapidamente supera os impactos de um porto com custo variável elevado.

Assim, navios que realizam operação de carga ou descarga em terminal com baixo custo variável de abastecimento devem aproveitar essa oportunidade para abastecer o máximo possível, evitando abastecimentos em portos mais caros no futuro. Na condução da pesquisa ação, a conclusão referente aos resultados observados foi desdobrada nas regras de abastecimento para o procedimento proposto. A próxima seção trata do cálculo dos custos de abastecimento realizados de 2017 de acordo com os custos modelados.

\section{4}

\section{Custo realizado de 2017}

Após a remoção das embarcações e escalas não relevantes, restaram para análise dados de 6.318 escalas de 114 embarcações. Dessas escalas, 54 foram realizadas apenas para abastecimento, sem envolver atividades de carga ou descarga de petróleo cru, GLP, derivados claros, escuros e especiais. Estas 54 escalas, 10 acarretaram em uma necessidade de desvio de rota, gerando trecho adicional de navegação apenas para abastecer.

Além das 54 escalas exclusivas para abastecimento, 11 escalas das rotas de cabotagem de 2017 estavam associadas a uma solicitação de abastecimento cancelada, terminando por não envolver atividade alguma. Vale ressaltar que, tendo volume de abastecimento realizado nulo, as 11 escalas sem atividade em que houve cancelamento de abastecimento não tiveram seus custos acrescentados ao custo total. Todavia, essas escalas também representaram incidência de custos portuários, excesso de estadia e até mesmo desvio de rota. Assim, espera-se que esse tipo de situação seja também evitado com uma tomada de decisão mais eficiente quanto aos abastecimentos, podendo representar uma economia adicional à estimada pela comparação de cenários real e proposto. A Figura 28 resume os tipos de escalas observados quanto à existência de atividade de transporte (carga ou descarga de petróleo e derivados) e abastecimento. 


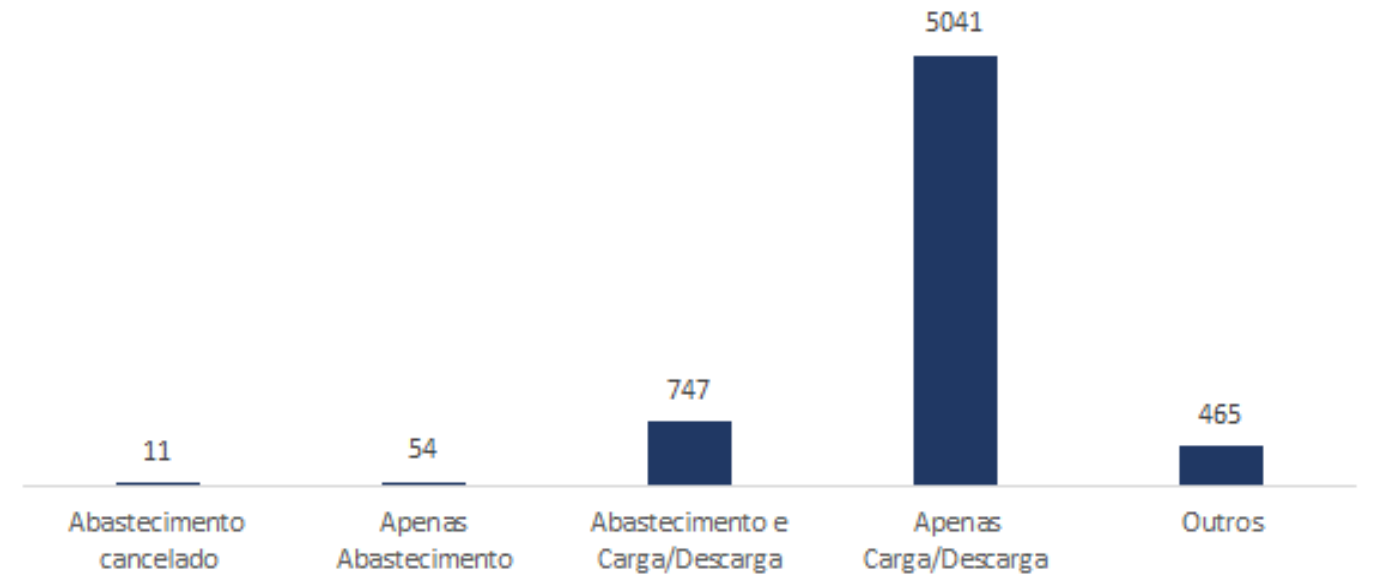

Figura 28 - Número de escalas por atividade realizada.

Fonte: A autora.

A Figura 29 ilustra na forma de um Diagrama de Venn quais escalas possuíram atividades de abastecimento e de carga ou descarga de derivados.

\section{Número de escalas por tipo de atividade}

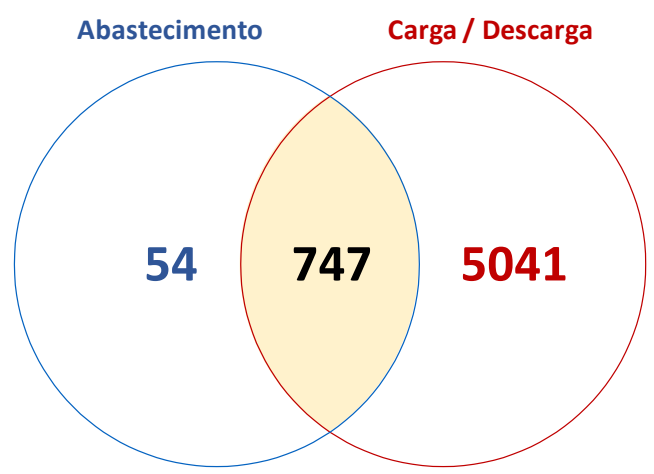

Figura 29 - Diagrama de escalas por tipo de atividade.

Fonte: A autora.

Ao aplicar os custos modelados para operações de abastecimento realizadas em 2017 o impacto da estadia de navios no custo total ficou evidente. As escalas só para abastecimento somaram um custo total de $\mathrm{R} \$ 17,8$ milhões, dos quais $\mathrm{R} \$$ 12,4 milhões foram referentes a estadia, $\mathrm{R} \$ 2,2$ milhões referentes a custos portuários, $\mathrm{R}$ \$ 1,5 milhões referentes a desvio de rota e apenas $\mathrm{R}$ \$ 1,7 milhões referentes a movimentação de produto. Essas 54 escalas representaram 39,6\% do custo total de abastecimento do cenário, que somou R\$ 45 milhões para as 801 operações de abastecimento realizadas. Algumas operações representaram individualmente custos de $\mathrm{R}$ \$ 1,4 milhões a R \$ 2,6 milhões. A Figura 30 detalha a 
representatividade de cada item de custo para os abastecimentos das rotas de cabotagem de 2017.

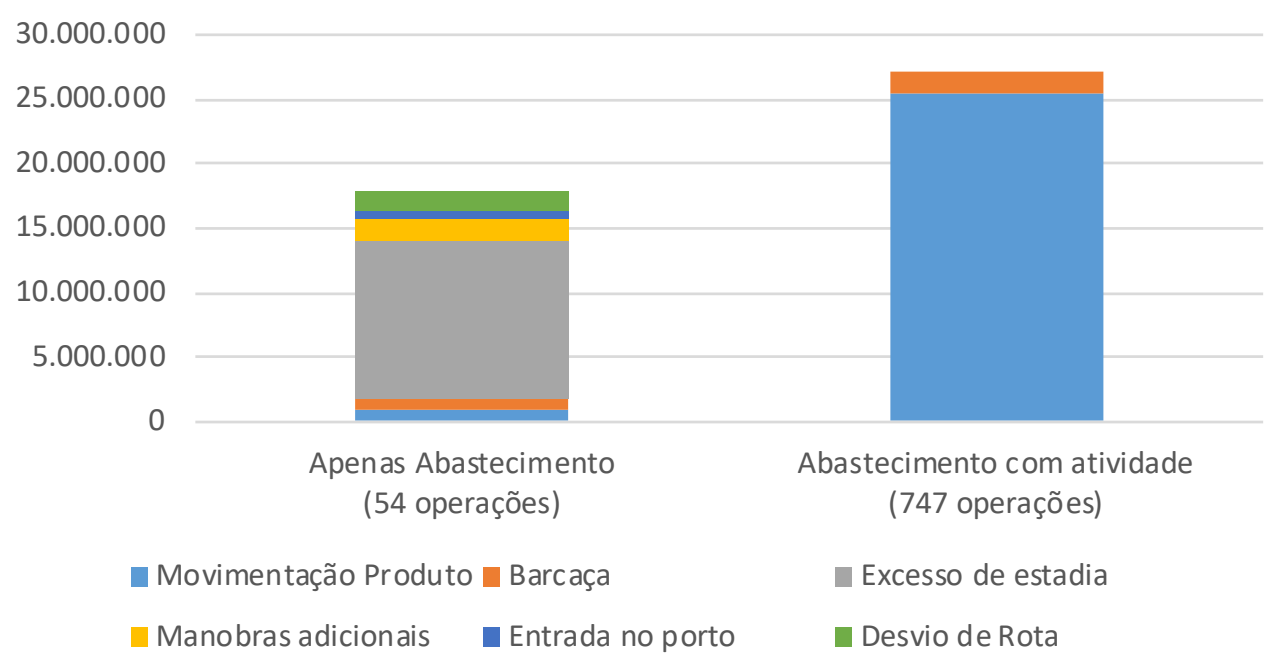

Figura 30 - Custos de abastecimento de 2017 por item.

Fonte: A autora.

As três operações de abastecimento mais onerosas somaram um custo de 5,4 milhões de reais, dos quais 5,1 milhões foram referentes a estadia. Todas elas se referiram a navios de 130.000 toneladas de porte aguardando abastecimento em Salvador. As estadias variaram entre 8 e 17 dias, em período do ano com maior ocorrência de mau tempo. A Figura 31 detalha os itens de custo dessas operações para cada embarcação abastecida.

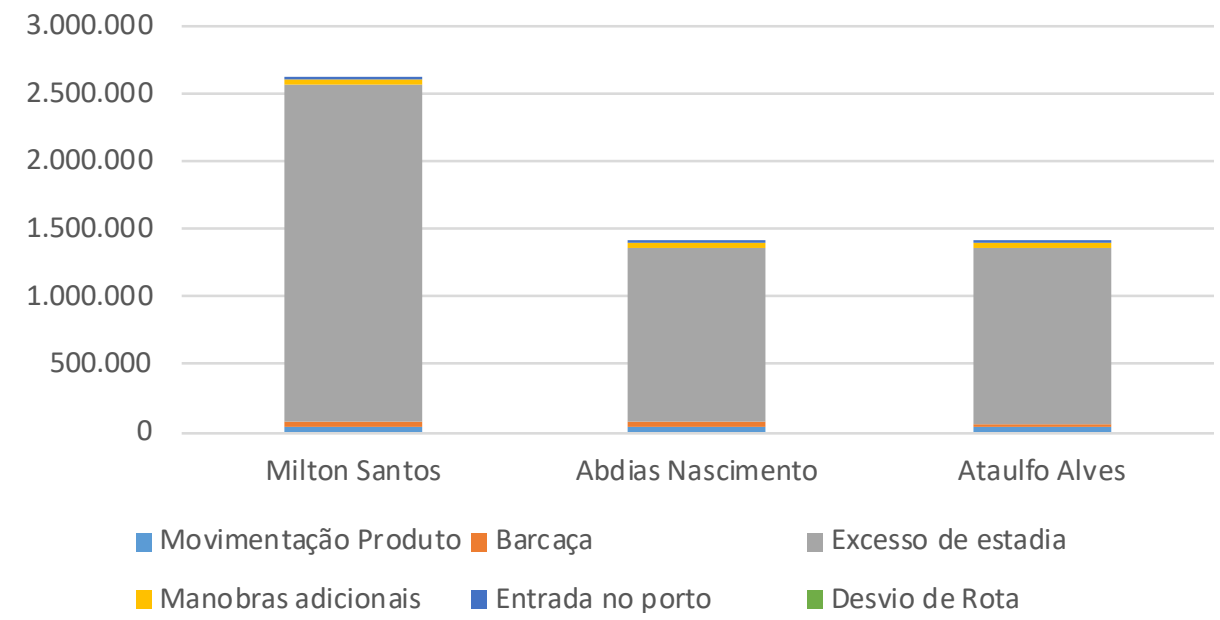

Figura 31 - Operações de abastecimento mais onerosas do Cenário Realizado.

Fonte: A autora.

Verificou-se que $90 \%$ das operações de abastecimento custaram até R\$100.000 cada, somando R\$ 24,2 milhões. As 73 operações restantes 
representaram um custo de R\$ 20,8 milhões. A Figura 32 mostra as ocorrências de abastecimento por faixas de custo.

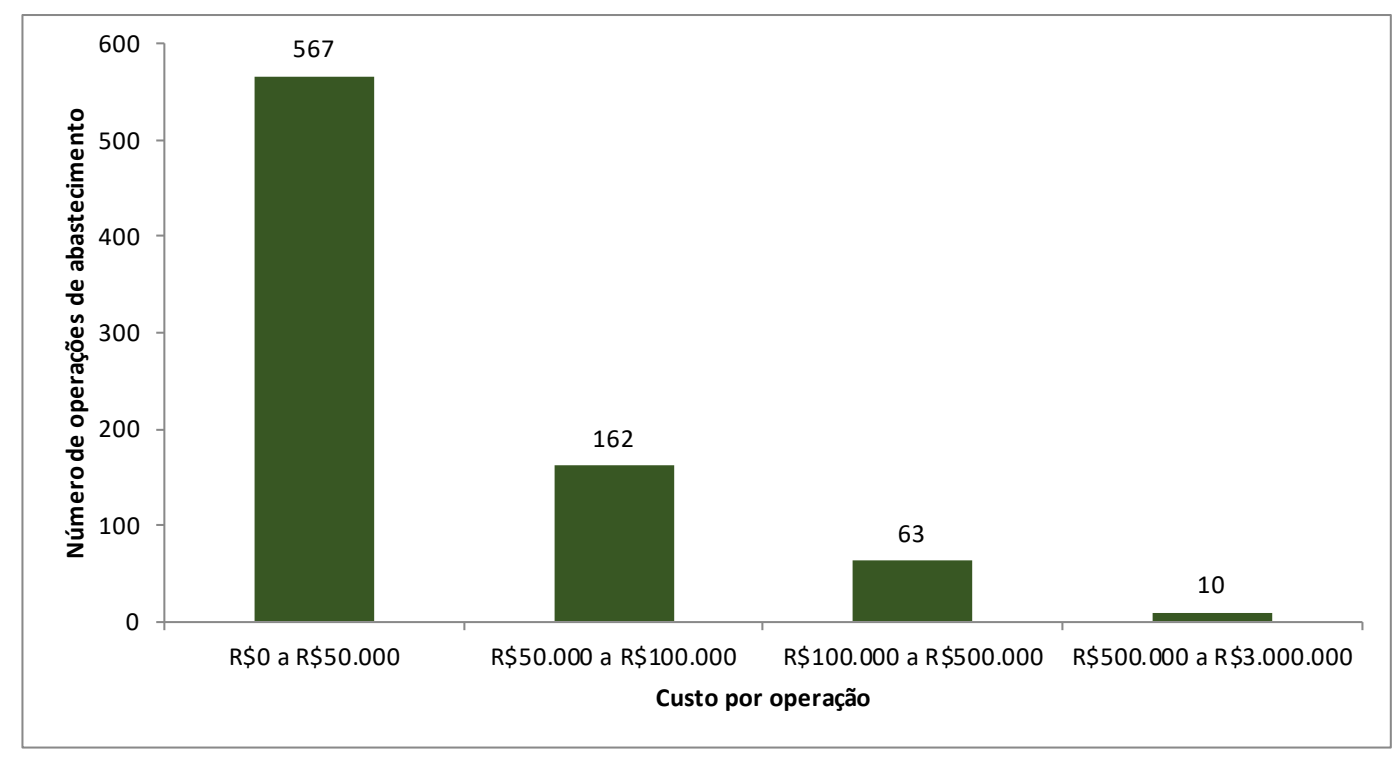

Figura 32 - Número de operações de abastecimento por faixa de custo.

Fonte: A autora.

Para os abastecimentos realizados em escala com atividade de carga ou descarga, a ocorrência mais onerosa foi de $\mathrm{R} \$ 182.000$. Os abastecimentos com custo total superior a R\$ 150.000 se referiram a navios da classe SUEZMAX abastecendo grandes volumes (de 2.000 a 2.500 toneladas) em Angra dos Reis e São Sebastião, portos dependentes de cabotagem de bunker.

Conforme mencionado anteriormente, onze escalas não possuíram atividade de carga e estavam associadas a uma solicitação de abastecimento cancelada. Apesar de não terem sido contabilizadas para o custo de abastecimentos total de 2017, essas escalas representaram R\$ 2,4 milhões de custos de transporte marítimo, sendo R 1,8 milhões referentes a estadia e $\mathrm{R} \$ 600$ mil referentes a custos portuários.

É esperado que essas situações sejam evitadas com uma tomada de decisão mais eficiente quanto aos abastecimentos, podendo representar uma economia adicional à estimada pela comparação de cenários real e proposto.

A fim de buscar uma redução nos custos de abastecimento, foi elaborado um fluxo de decisão de abastecimento para simulação de economias nas escalas de 2017. A próxima seção detalha esse fluxo e sua elaboração. 


\section{5}

\section{Fluxo de decisão de abastecimento}

O cálculo do custo realizado de 2017 mostrou grande impacto no custo total do cenário pelas escalas realizadas exclusivamente para abastecer. Assim, foram analisadas as rotas dos navios que realizaram essas escalas de modo a identificar a causa para a baixa autonomia de navegação que gerou a necessidade de parar o navio em um porto apenas para abastecer. Foi verificado que, na maioria dos casos, as embarcações deixaram de abastecer em portos habilitados para fornecimento de bunker, colocando sua autonomia em risco.

Em discussão com as equipes foi avaliado que o abastecimento não realizado nessas escalas poderia se tratar de abastecimento não solicitado pela existência de diversos portos com abastecimento habilitado na programação posterior. Foi ressaltado que essa situação representa risco de autonomia, dada que a natureza dinâmica da atividade de programação pode facilmente substituir o destino do navio de forma que o mesmo não se dirija mais a um porto habilitado para abastecimento.

A situação é agravada pelo processo interno da empresa que exige três dias úteis de antecedência para solicitação de abastecimento para a área comercial de bunker, prazo muito superior ao exigido para programação de carga ou descarga de petróleo e derivados em um ponto operacional. Foi verificado que, a fim de não infringir o prazo acordado entre as áreas, em ocasiões o abastecimento era solicitado para uma escala mais à frente em vez da próxima escala programada. Assim, havendo reprogramação do navio em seguida, o abastecimento simplesmente deixaria de ser realizado. Os impactos do prazo exigido foram ressaltados para a área comercial, que reviu a necessidade de antecedência nas solicitações de abastecimento em modalidade pipe (abastecimento por duto), terminando por isentar a frota de antecedência para essa modalidade.

Além dessa iniciativa, a pesquisa gerou um fluxo de decisão de abastecimento padrão, ilustrado na Figura 33. Através da classificação dos portos com abastecimento disponível em três categorias - "Abastecimento Máximo”, “Abastecimento Intermediário” e “Abastecimento Mínimo” - foi possível estabelecer regras gerais de quando e quanto abastecer. 
O fluxo de decisão foi então simulado para as rotas selecionadas de 2017. A proposta busca reduzir os custos operacionais orientando qual volume abastecer em cada porto em que há operação de carga e descarga. A intenção é evitar ao máximo as escalas apenas para abastecimento, acionando-as apenas quando necessário. Para os abastecimentos que constaram em ambos cenários (real e proposto), o modal do cenário proposto se iguala àquele do cenário real. Já para novos abastecimentos, busca-se o modal mais econômico para o porto em questão.

Para garantir que os navios não abastecessem volume superior à sua capacidade ou que seus estoques se reduzissem além do limite de segurança, foi levantado o volume de bunker disponível em cada navio no início do horizonte de estudo. Em seguida, foi projetado o bunker disponível em cada escala subsequente considerando os abastecimentos indicados pelo fluxo e restrições semelhantes às do modelo de Zhen et al. (2017), descritas no Capítulo 2.

Para refletir corretamente a particularidade de disponibilidade de abastecimento de Fortaleza, conforme descrito na Subseção 4.1.2, foi levantado junto à equipe de operação de navios quais armadores haviam permitido que suas embarcações abastecessem o produto com teor de acidez elevado típico desse ponto. 


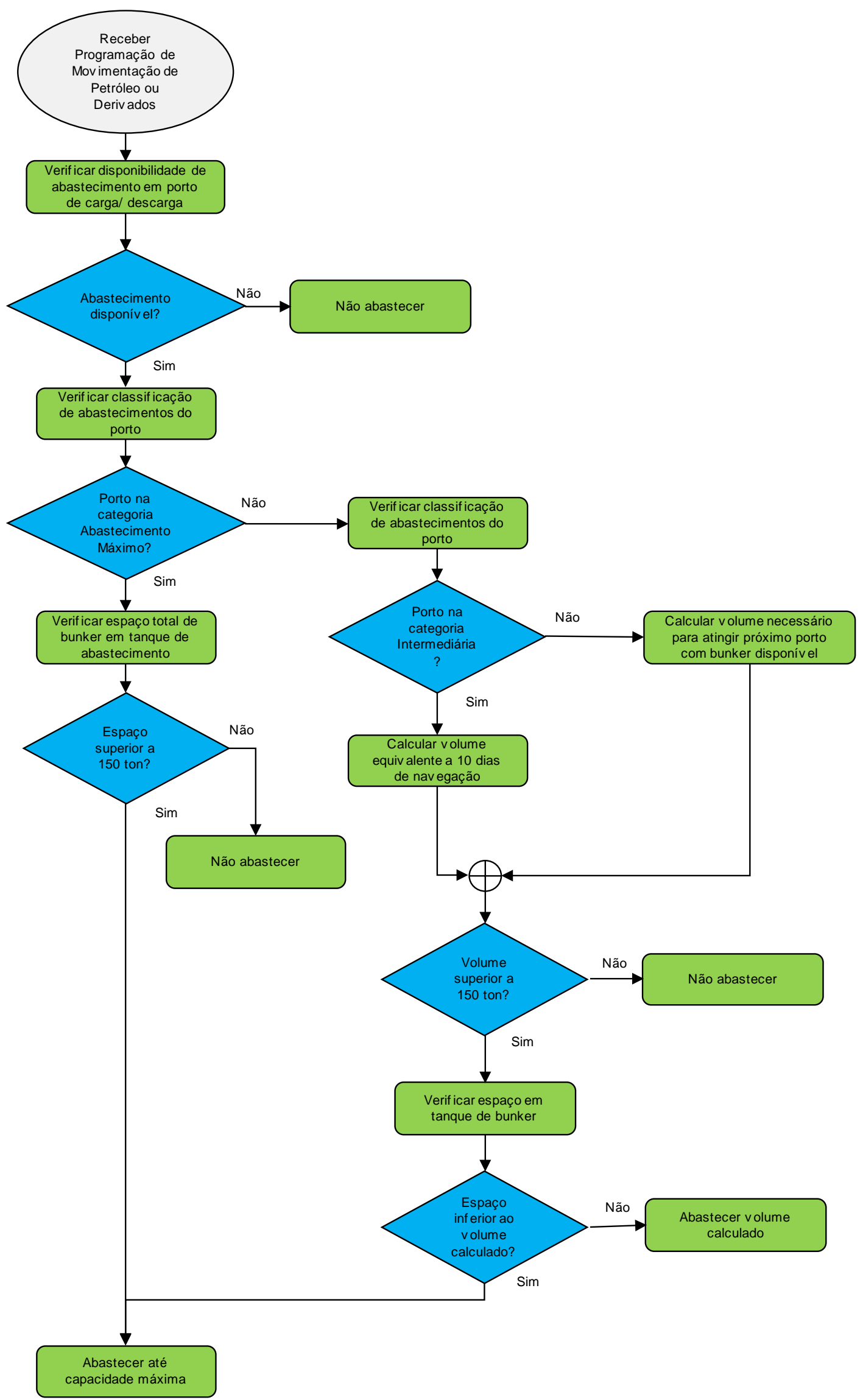

Figura 33 - Fluxo de decisão de abastecimento proposto.

Fonte: A autora. 
Para esses navios, o porto de Fortaleza foi liberado no procedimento e inclusive encorajado, dados os baixos custos variáveis do terminal, classificado como "Abastecimento máximo”. Para os demais navios, o porto foi tratado como abastecimento indisponível, de forma a não distorcer as economias do procedimento proposto com abastecimentos inviáveis na prática.

Como resultado da aplicação do procedimento, nenhum abastecimento por barcaça foi proposto além daqueles já realizados em 2017. A maximização de volume abastecido em portos econômicos permitiu que a maioria das escalas apenas para abastecer fossem evitadas. Apenas duas escalas exclusivas para abastecimento foram mantidas, nenhuma das quais envolviam desvio de rota

Ademais, apenas duas escalas exclusivas para abastecimento foram de fato necessárias, eliminando-se então 52 escalas desse tipo. Foi verificada a autonomia das embarcações que se mostrou sempre positiva, não sendo necessário revisar a lógica de abastecimento proposta.

Após aplicada a lógica de abastecimento às rotas de 2017, foi estimado o custo total de abastecimentos do cenário proposto. Como as escalas exclusivas para abastecimento representavam quase $40 \%$ do custo do cenário, o procedimento proposto representou um grande potencial de economia.

O procedimento foi validado com os operadores a fim de verificar sua aderência ao dia-a-dia da programação de navios. No momento da validação, foi proposta a reclassificação do porto mais oneroso da categoria “Abastecimento intermediário” para a categoria “Abastecimento mínimo”. Foi gerada uma nova rodada de procedimento proposto com essa reclassificação. Novamente a autonomia foi respeitada, acionando-se apenas duas das 54 escalas de abastecimento fora da rota. A reclassificação é ilustrada na Figura 34.

Com o porto de Belém classificado como “Abastecimento intermediário”, em que a cada escala no porto o navio abastece o equivalente a dez dias de consumo, o custo total do cenário proposto foi de R \$32,3 milhões, representando um potencial de economia de R\$ 12,7 milhões com relação ao realizado de 2017. Já após a reclassificação desse porto como "Abastecimento mínimo”, categoria em que o abastecimento é limitado ao estritamente necessário para alcançar o próximo porto mais um volume de segurança, foi encontrado um potencial de economia de R \$ 14,8 milhões com relação ao custo realizado. Isso ocorreu, pois, os abastecimentos em Belém se tornaram mais escassos em detrimento de maior 
volume abastecido em portos mais econômicos. Ainda assim foi possível eliminar a maioria das escalas exclusivas para abastecimento, mantendo os mesmos dois episódios da proposta anterior.

MANAUS
FORTALEZA
RIO DE JANEIRO
SANTOS
SALVADOR
RIO GRANDE
SAO SEBASTIAO
ANGRA DOS REIS
PARANAGUA
BELEM
ARATU
VILA DO CONDE
VITORIA
TUBARAO

MANAUS
FORTALEZA
RIO DE JANEIRO
SANTOS
SALVADOR
RIO GRANDE
SAO SEBASTIAO
ANGRA DOS REIS
PARANAGUA
BELEM
ARATU
VILA DO CONDE
VITORIA
TUBARAO

Legenda:

Abastecimento máximo

Abastecimento intermediário

Abastecimento mínimo

Figura 34 - Reclassificação do porto de Belém.

Fonte: A autora.

Trata-se de um potencial de economia relevante, principalmente ao se considerar que se está apenas estruturando o procedimento de solicitação de abastecimentos, sem necessidade de investimentos. A Figura 35 compara os custos totais de abastecimento entre os cenários Realizado, Proposto e Proposto Atualizado - este último com Belém classificado como “Abastecimento mínimo”.

\section{Custos de abastecimento por cenário}

( $R \$$ milhões)

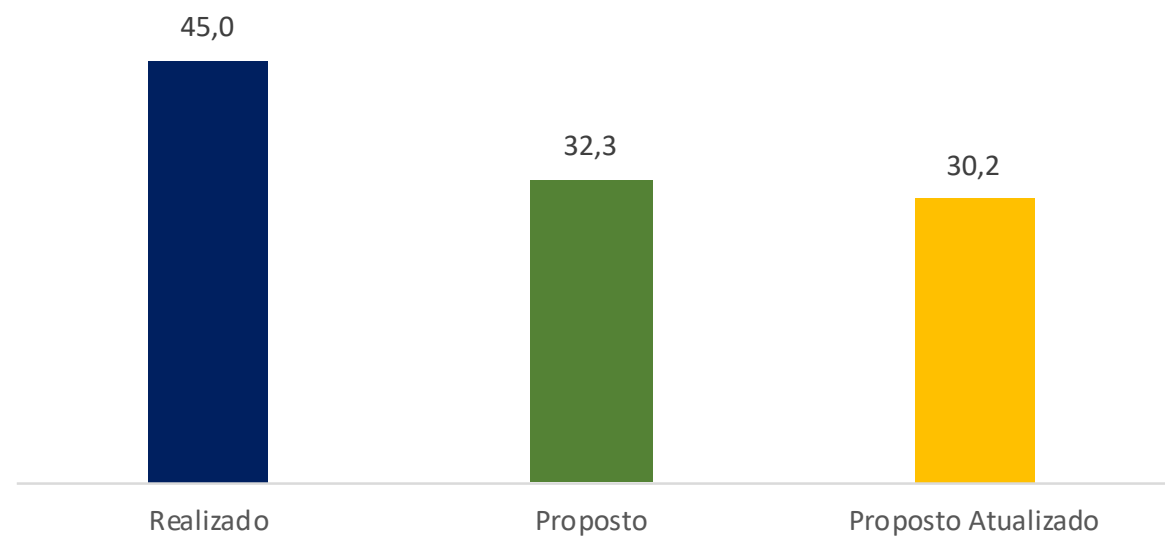

Figura 35 - Custos de abastecimento por cenário.

Fonte: A autora. 
Com a eliminação de grande parte das escalas exclusivas para abastecimento, as três operações mais onerosas do Cenário Proposto Atualizado consistiram nas duas escalas exclusivas para abastecimento que não puderam ser eliminadas e um abastecimento por duto de grande volume. A soma do custo das três operações é de 1,7 milhões de reais, equivalente a um terço do custo das três operações mais onerosas do Cenário Realizado. A Figura 36 detalha os itens de custo das três operações em questão por nome da embarcação abastecida.

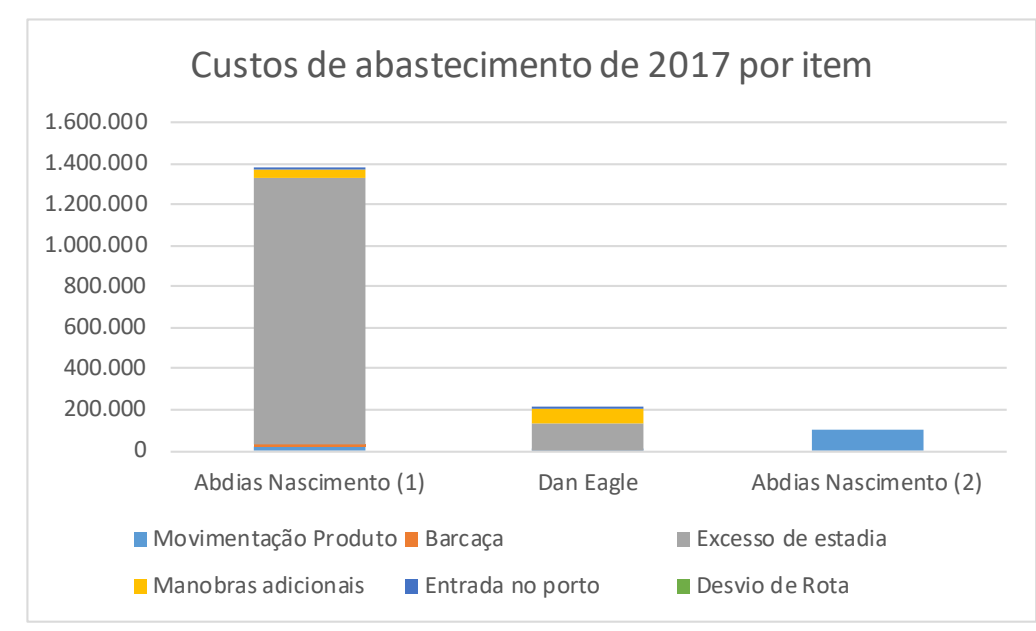

Figura 36 - Operações mais onerosas do Cenário Proposto.

Fonte: A autora.

Vale ressaltar que o cenário proposto correspondeu a 1736 operações de abastecimento e um volume total de 630 mil toneladas abastecidas no ano, contra 803 operações totalizando 523 mil toneladas do cenário realizado. Apesar do maior número e volume de abastecimentos, o cenário proposto indicou redução de custos por evitar as escalas realizadas apenas para abastecer, o que foi possível mantendo os navios da frota com maior estoque médio de bunker.

A fim de averiguar possibilidade de economias adicionais, foi avaliada a inclusão de novos pontos de abastecimento. A seleção dos pontos para teste está detalhada na próxima seção.

\section{6}

\section{Avaliação de novos pontos de abastecimento}

Após a definição das economias viáveis a partir da estruturação do processo de tomada de decisão de abastecimento, foi avaliado o impacto na inclusão de novos pontos de abastecimento ao procedimento proposto. Os dez pontos cuja 
disponibilidade de abastecimento foi classificada como potencial foram listados de modo a ter seus custos operacionais estimados caso fossem habilitados para abastecer navios. Os pontos podem ser observados na Tabela 13.

Tabela 13 - Pontos operacionais potenciais para abastecimento.

\begin{tabular}{lc}
\hline Ponto Operacional & UF \\
\hline COARI & AM \\
ITACOATIARA & AM \\
SAO LUIS & MA \\
PECEM & CE \\
CABEDELO & PB \\
SUAPE & PE \\
MACEIO & AL \\
BARRA DO RIACHO & ES \\
PORTO DO AÇU & RJ \\
PORTO ALEGRE & RS \\
\hline
\end{tabular}

Fonte: A autora.

Em um primeiro momento foi avaliado o uso dos pontos em questão a fim de verificar o interesse em tratá-los como pontos alternativos para abastecimento da frota de cabotagem. O terminal de Pecém foi descartado como ponto potencial dada sua utilização exclusiva pela frota de GNL, que realiza exclusivamente viagens de importação e exportação. O Porto do Açu foi igualmente descartado, dado que só é utilizado pela frota que transporta diesel marítimo para plataformas, também expurgada dos dados de 2017. O porto de Coari foi descartado porque os navios que operam em Coari têm sempre como origem ou destino o porto de Manaus, podendo ser abastecidos simultaneamente à operação na capital amazonense. Situação semelhante ocorre em Porto Alegre, no Rio Grande do Sul, dada a passagem obrigatória dos navios pelo fundeadouro de Rio Grande a cada operação.

Os demais seis pontos tiveram seu custo variável estimado em função da necessidade de transportar o bunker por cabotagem, indisponibilidade de abastecimento por duto e da tarifa Transpetro.

Dada a intenção de incluir os novos pontos com o objetivo de minimizar as escalas exclusivas para abastecimento, os custos portuários foram desconsiderados da análise, pois os mesmos estariam associados às atividades de carga ou descarga. 
Após a estimativa de custos, os dados foram compartilhados com as equipes de operação e programação em entrevistas para definir quais pontos deveriam ter sua habilitação para abastecimento testada nas rotas de 2017 para verificar possível redução de custos operacionais. Foi apontado pela equipe que os pontos dependentes de barcaça deveriam ser descartados, dados os custos envolvidos e o fato que a decisão de alocação de barcaça é feita em função de vendas e não entregas para a frota. Dentre os pontos com potencial abastecimento por duto, foi indicado o porto de São Luís para teste, dada a sua estrutura de abastecimento já existente e a retomada de abastecimentos nesse terminal em 2018. Por fim, o porto de Suape - que apresentou menor custo variável calculado - foi apontado unanimemente entre operadores e programadores como candidato favorável para verificação de economias. Nas entrevistas, diversos aspectos do terminal foram elencados como atrativos para a realização de abastecimentos:

- Frequência total de uso do porto;

- Frequência de uso do porto em rotas sem pontos de abastecimento alternativo;

- Atendimento a navios diversos grupamentos de produto e embarcações (petróleo cru, GLP, derivados claros e derivados escuros);

- Baixo custo esperado de suprimento para o porto, dada sua proximidade à RNEST;

- Favorabilidade de condições operacionais como portes de embarcação aceitos e profundidade.

Após a seleção, os portos de São Luís e Suape foram incluídos no cenário de procedimento proposto com os custos variáveis estimados. Inicialmente acrescentou-se cada ponto individualmente. A inclusão do porto de Suape permitiu eliminar uma escala adicional das escalas realizadas apenas para abastecer. Assim, das 54 escalas apenas para abastecer realizadas em 2017, apenas uma permaneceria com a inclusão de Suape. Classificando este porto na categoria “Abastecimento Máximo”, o custo total do cenário representou um potencial de economia adicional de R $\$ 4$ milhões ao cenário com o procedimento proposto, totalizando R\$ 18,8 milhões de economia potencial com relação ao realizado. Apesar do baixo custo variável calculado para o porto, foram realizados novos 
cálculos reclassificando o porto de Suape como categorias "Abastecimento Intermediário” e “Abastecimento Mínimo”. Com as reclassificações, o potencial de redução de custos estimado foi inferior. A Figura 37 ilustra os resultados da inclusão do porto de Suape.

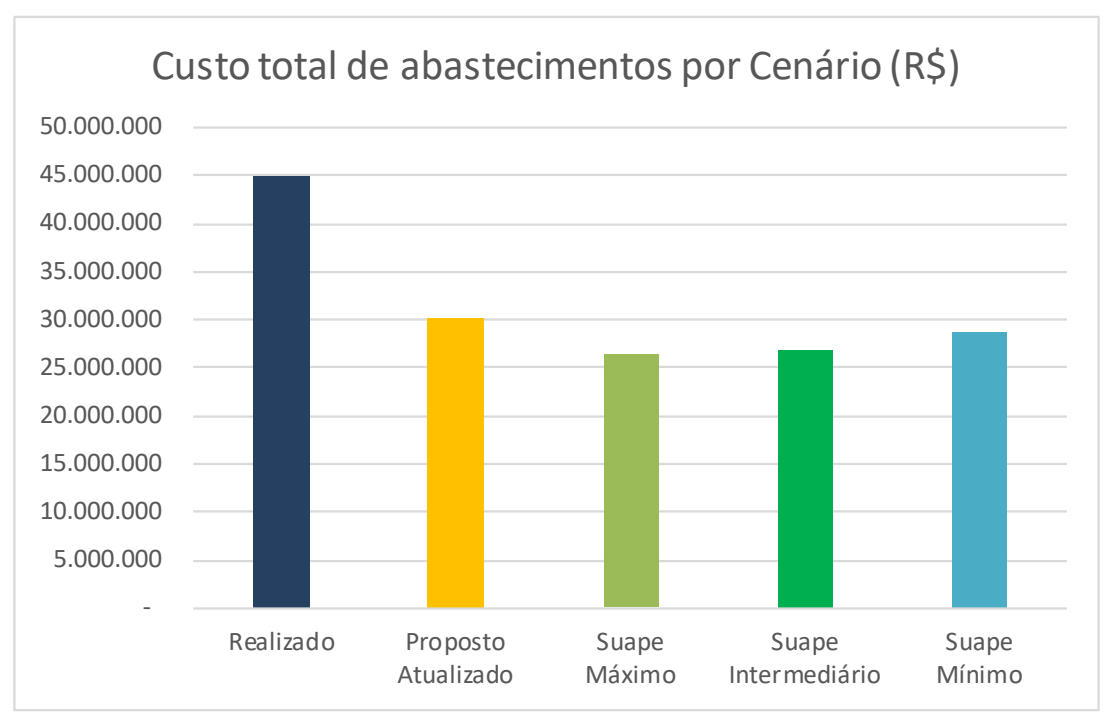

Figura 37 - Custo total de abastecimentos com inclusão do porto Suape.

Fonte: A autora.

A inclusão de São Luís não apresenta economias com relação ao cenário Proposto Atualizado. O elevado custo variável decorrente da cabotagem de bunker necessária para disponibilizar produto nesse ponto torna desaconselhável o abastecimento da frota nesse ponto em detrimento daqueles com fornecimento de bunker local. Mesmo quando este porto foi classificado como "Abastecimento Mínimo”, o custo do cenário com sua inclusão ultrapassou o custo do Proposto Atualizado. A Figura 38 compara os custos com a inclusão de São Luís.

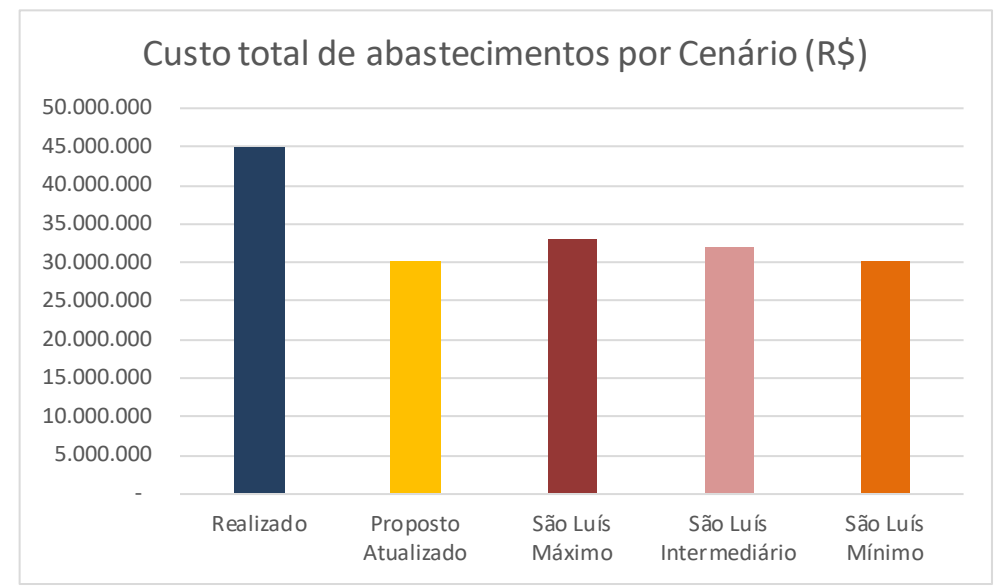

Figura 38 - Custo total de abastecimentos com inclusão do porto São Luís.

Fonte: A autora. 
A inclusão dos portos de forma conjunta mantém a tendência observada:

- quanto maior a frequência e volume de abastecimentos em Suape, menor o custo do Cenário;

- quanto maior a frequência e volume de abastecimentos em São Luís, maior o custo do Cenário.

Assim, as categorias mais indicadas para o acionamento conjunto dos portos são categoria “Abastecimento Máximo” para Suape e categoria “Abastecimento Mínimo” para São Luís. Essa inclusão conjunta, todavia, ainda ultrapassou a inclusão do porto de Suape exclusivamente em termos de custos. A Figura 39 compara os cenários de cada porto individualmente com a inclusão de ambos os portos simultaneamente.

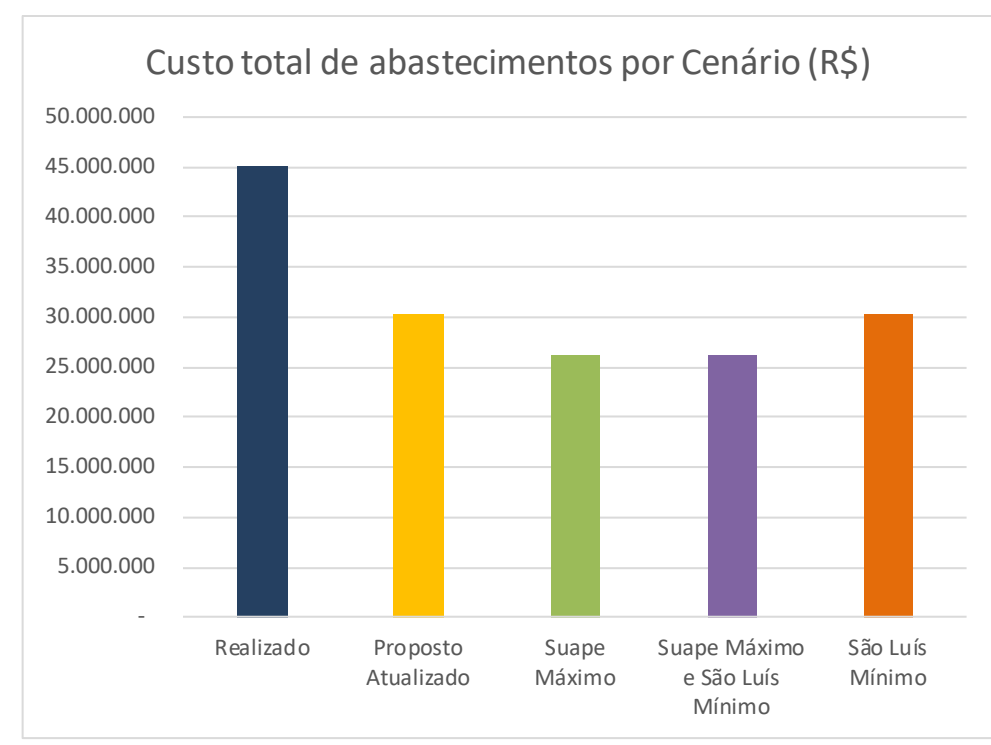

Figura 39 - Custo total de abastecimentos com inclusão dos portos Suape e São Luís.

Fonte: A autora.

Ao apresentar os resultados encontrados para a equipe de programação, foi apontado que a inclusão de novos portos deve proporcionar economias adicionais às estimadas pela observação dos dados de 2017. O potencial de economia apontado nesta dissertação foi estimado considerando que a alocação de navios às rotas de 2017 foram feitas da melhor forma possível. Todavia, a própria restrição de autonomia dos navios frequentemente obriga a equipe de programação a realizar trocas entre programações designadas para diferentes navios. Assim, um navio que seria idealmente utilizado na rota A sinaliza que não terá autonomia para completá-la, obrigando a programação a direcionar o navio para a rota B; e 
atribuindo à rota $\mathrm{A}$ um navio que seria melhor utilizado na rota $\mathrm{B}$. Isso pode representar uma série de custos, como:

- Custo de lavagem de tanques para carga de um produto diferente,

- Custo de excesso de estadia caso o navio chegue no porto antes do necessário,

- Custo de consumo adicional de combustível, caso o navio aumente a velocidade de navegação para atingir o porto na janela necessária,

- Custos de desvio caso o navio posicionado mais ao norte se direcione à programação mais ao sul e vice-versa.

Assim, a redução de custos referente ao ganho de flexibilidade na programação com a inclusão de novos pontos de abastecimento pode representar economias adicionais às estimadas nesse trabalho. Dada a relevância do uso do porto de Suape, espera-se que a habilitação deste ponto para abastecimentos traga economias ainda mais significativas no aproveitamento da frota do que os $\mathrm{R} \$ 18,8$ milhões estimados. 


\section{Conclusão}

Tendo em vista a relevância da navegação de cabotagem para economia do país e particularmente para as operações da Petrobras, essa dissertação tem como objetivo principal prover uma solução que reduza os impactos de custos operacionais causados pelas operações de abastecimento de navios da frota de cabotagem. Em se tratando de abastecimento de navios da frota de uma empresa de energia verticalizada, objeto de estudo não encontrado na literatura, a solução envolveu um modelo de custos que conciliou aspectos observados por trabalhos focados em fornecimento de bunker, como Drake (2003) e Cristo (2014), com trabalhos centrados em custos de transporte marítimo, como Moreira (2008) e Diz et al. (2014), além de observar estudos relativos a decisões de abastecimento para outros perfis de frota (Darnell et al., 1977 e Zhen et al., 2017).

O modelo foi em seguida desdobrado em um simulador de custos de abastecimento, uma ferramenta de apoio à decisão e um fluxo de decisão padronizado para solicitações de abastecimento. O protótipo da ferramenta foi desenvolvido no software Microsoft Excel e após desenvolvimento final, ela será disponibilizada para a força de trabalho através da plataforma TIBCO Spotfire. A ferramenta lista os portos em que é possível abastecer por ordem crescente de custos para os dados alimentados pelo usuário, esclarecendo qual a relevância de cada item de custo e respeitando as restrições operacionais de cada porto. O fluxo de decisão busca reduzir os custos totais de abastecimento, priorizando abastecimentos nos pontos mais econômicos para a Petrobras e buscando eliminar as escalas realizadas exclusivamente para abastecer.

Embora a companhia demonstre internamente uma preocupação com redução de custos operacionais e redução de consumo de combustível nas embarcações, não havia até esse estudo um processo estruturado na tomada de decisão de abastecimento da frota. O fluxo de decisão foi testado nas rotas realizadas de 2017 e mostrou um potencial de economia de até $\mathrm{R} \$ 14,8$ milhões (equivalente a 33\% dos custos de abastecimento do Cenário Realizado) sem necessidade de investimentos. Essa pesquisa ação também avaliou a redução de 
custos potencial nas rotas de 2017 caso os portos de São Luís e Suape oferecessem abastecimentos. Apesar do indicativo dos testes sinalizar um potencial de economia adicional de até $\mathrm{R} \$ 4$ milhões na inclusão do porto de Suape, as equipes de programação e operação acreditam que a flexibilidade ganha na roteirização com a viabilidade de abastecimento nesses pontos pode gerar economias ainda maiores.

Conforme mencionado na introdução, as perguntas de pesquisa deste trabalho foram:

1. Como são feitos os abastecimentos de navios da frota de cabotagem de Petróleo e Derivados?

2. Como modelar os custos envolvidos em uma operação de abastecimento para uma empresa verticalizada de energia?

3. É possível reduzir os custos de abastecimento a partir da estruturação da decisão de onde e quanto abastecer? Qual a economia esperada?

4. Como selecionar potenciais pontos de abastecimento que tragam redução nos custos operacionais atuais?

5. Qual a economia esperada com o acréscimo dos pontos de abastecimento considerando as rotas realizadas no último ano?

A dissertação respondeu todas as perguntas de pesquisa:

1. As operações de abastecimento foram detalhadas na Seção 4.1.

2. A metodologia desenvolvida para modelagem de custos foi descrita na Seção 3.4.

3. A redução de custos com a estruturação do processo de decisão é possível e a economia esperada foi apresentada na Seção 4.5.

4. O método de seleção de novos pontos de abastecimento foi detalhado na Seção 4.6.

5. A economia esperada com a inclusão de novos portos também foi apresentada na Seção 4.6. 


\section{1}

\section{Trabalhos futuros}

No desenrolar desta pesquisa ação se observaram oportunidades de pesquisas futuras no âmbito da Petrobras, cuja participação relevante no transporte marítimo nacional pode contribuir para a academia inclusive com aplicações práticas de modelos observados na literatura.

Dentre as oportunidades vislumbradas pela equipe ao longo da pesquisa estão:

- Avaliar o ganho potencial nas rotas de importação e exportação com a inclusão de novos pontos de abastecimento;

- Dimensionar reduções de custo de transporte marítimo proporcionadas por flexibilidade na roteirização a partir da inclusão de novos pontos operacionais com disponibilidade de abastecimento;

- Avaliar o impacto da necessidade de ressuprimentos que não de MF no aproveitamento da frota, como abastecimentos de MGO, alimentação, água potável, água para lavagem de tanques etc.;

- Incluir acompanhamento de autonomia das embarcações no roteirizador da frota de cabotagem da companhia. 


\title{
Referências bibliográficas
}

\author{
ANTAQ, Boletim Informativo Aquaviário - $2^{\mathbf{o}}$ Trimestre 2017. Agência \\ Nacional de Transportes Aquaviários. 2017. Disponível em: \\ http://portal.antaq.gov.br/wp-content/uploads/2017/03/Boletim-Informativo- \\ 2T2017.pdf. Acessado em outubro de 2017.
}

AYDIN, N., LEE, H., MANSOURI, S. A., Speed optimization and bunkering in liner shipping in the presence of uncertain service times and time windows at ports. OR Spectrum, 2017, 36, p. 455-480

BESBES, O., SAVIN, S., Going Bunkers: The Joint Route Selection and Refueling Problem. Manufacturing \& Service Operations Management, 2009, 11, 4, p. 694-711.

CARMO, J. L., Prática de otimização de consumo de óleo combustível no aquecimento da carga. Rio de Janeiro: Prêmio Apoena Petrobras, 2014.

CHRISTIANSEN, M.; FAGERHOLT, K.; NYGREEN, B.; RONEN, D., Maritime transportation. Handbooks in Operations Research and Management

Science: Transportation. v.14, p.189-284. Amsterdam, 2007.

CRISTO, C. M., Medindo a satisfação do cliente B2B: uma ferramenta para gestão de serviços. Rio de Janeiro, 2014, 43p. Monografia (Especialização em MBA Gestão de Negócios). - Escola Superior de Propaganda e Marketing.

DARNELL, D., LOFLIN, C., National airlines fuel management and allocation model. Interfaces, 1977, 7, 2, p. 1-11.

DIZ, G., SCAVARDA, L. F., ROCHA, R., HAMACHER, S., Decision Support System for PETROBRAS Ship Scheduling. Interfaces, 2014, 44, 6, p. 555-566.

DRAKE, R., Cost benefit analysis of pier refueling versus barge refueling at the Fleet Industrial Supply Center Fuel Facility Pearl Harbor, Hawaii. Monterey, 2003, 43p. Monografia (MBA). - Naval Postgraduate School.

FARAH, M.A., Petróleo e seus derivados: definição, constituição, aplicação, especificações, características de qualidade. Rio de Janeiro: LTC, 2015. 226p.

GHOSH, S., LEE, L. H., NG, S.H., Bunkering decisions for a shipping liner in an uncertain environment with service contract. Production, Manufacturing and Logistics, 2015, 244, p. 792-802.

HUANG, H.B., What is good action research? Why the resurgent interest? Action Research, 2010, 8, p. 93-109. 
MOREIRA, E. C., Gestão de custos logísticos baseada em atividades e no custo total de propriedade. Rio de Janeiro, 2008, 59p. Dissertação (Mestrado Profissional em Logística). - PUC-Rio.

PEDRIELLI, G., LEE, L. H., NG, S.H., Optimal bunkering contract in a buyer-seller supply chain under price and consumption uncertainty. Transportation Research, 2015, E, 77, p. 77-94.

PETROBRAS, Plano de Negócios e Gestão 2018-2022. Petróleo Brasileiro S.A. 2018. Disponível em: http://www.petrobras.com.br/pt/quem-somos/estrategia/ plano-de-negocios-e-gestao/. Acessado em março de 2018.

PRADA JUNIOR, A. F., Avaliação da qualidade de ignição para utilização de petróleos pesados e asfálticos como combustíveis marítimos. Rio de Janeiro, 2007, 100p. Dissertação (Mestrado em Engenharia Química). - Universidade do Estado do Rio de Janeiro.

SHENG, X., LEE, L. H., CHEW, E. P., Dynamic determination of vessel speed and selection of bunkering ports for liner shipping under stochastic environment. OR Spectrum, 2014, 36, p. 455-480.

SCOFIELD, J., Laytime and Demurrage. Oxon: Informa Law, 2013.

SUZUKI, Y., DAI, J., Decision Support System of Truck Routing and Refueling: A Dual-Objective Approach. Decision Sciences Journal, 2013, 44, 5, p. 817-842.

TRANSPETRO, Informações Portuárias - Terminal Belém. Transpetro. 2006. Disponível em: http://www.transpetro.com.br/pt_br/areas-de-negocios/terminaise-oleodutos/informacoes-portuarias.html. Acessado em abril de 2018.

\begin{tabular}{llllr} 
& Tarifas de Transporte de Petróleo e Derivados em Dutos \\
\hline Curtos. & Transpetro. & 2017. & Disponível & em:
\end{tabular} http://www.transpetro.com.br/pt_br/fale-conosco/canal-do-cliente/terminais-eoleodutos/tarifas.html. Acessado em dezembro de 2017.

WANG, S., MENG, Q., Robust bunker management for liner shipping networks. European Journal of Operational Research, 2015, 243, p. 789-797.

WANG, S., MENG, Q., LIU, Z., Bunker consumption optimization methods in shipping: a critical review and extensions. Transportation Research, 2013, E, 53, p. 49-62.

WANG, Y., YEO, G., NG, A., Choosing optimal bunkering ports for liner shipping companies: A hybrid Fuzzy-Delphi-TOPSIS approach. Transport Policy, 2014, 35, p. 358-365.

WANG, X., FAGERHOLT, K., WALLACE, S. W., Planning for charters: A stochastic maritime fleet composition and deployment problem. Omega, 2017, 79, p. 54-66. 
WESTBROOK, R., Action research: a new paradigm for research in production and operations management. International Journal of Operations \& Production Management, 1995, 15, 12, p. 6-20.

YAO, Z., NG, S. H., LEE, L. H., A study on bunker fuel management for the shipping liner services. Computer \& Operations Research, 2012, 39, p. 11601172.

ZHEN, L., WANG, S., ZHUGE, D., Dynamic Programming for optimal ship refueling decision. Transportation Research, 2017, E, 100, p. 63-74.

ZOCKAIE, A., AASHTIANI, H., GHAMAMI, M., NIE, Y., Solving DetourBased Fuel Station Location Problems. Computer-Aided Civil and Infrastructure Engineering, n. 31, p. 132-144. 


\section{Apêndice 1 - Detalhamento de Pontos Operacionais}

\begin{tabular}{|c|c|c|}
\hline Porto & Detalhamento & Classificação \\
\hline COARI & Terminal & Potencial \\
\hline MANAUS & Terminal & Disponível \\
\hline ITACOATIARA & Terminal & Potencial \\
\hline BELEM & Terminal & Disponível \\
\hline VILA DO CONDE & Terminal & Disponível \\
\hline SAO LUIS & Terminal & Potencial \\
\hline XAREU & Plataforma & Inviável \\
\hline FORTALEZA & Terminal & Disponível \\
\hline PECEM & Terminal & Potencial \\
\hline GUAMARE & Monoboia & Inviável \\
\hline CABEDELO & Terminal & Potencial \\
\hline SUAPE & Terminal & Potencial \\
\hline MACEIO & Terminal & Potencial \\
\hline ARACAJU & Monoboia & Inviável \\
\hline FPSO PIRANEMA & Plataforma & Inviável \\
\hline ARATU & Terminal & Disponível \\
\hline SALVADOR & Terminal & Disponível \\
\hline NORTE CAPIXABA & Monoboia & Inviável \\
\hline BARRA DO RIACHO & Terminal & Potencial \\
\hline TUBARAO & Terminal & Disponível \\
\hline VITORIA & Terminal & Disponível \\
\hline PORTO DO AÇU & Terminal & Potencial \\
\hline B CAMPOS - STS & Monoboia & Inviável \\
\hline FPSO - P-43 (BARRACUDA) & Plataforma & Inviável \\
\hline FPSO - P-48 (CARATINGA) & Plataforma & Inviável \\
\hline FPSO CAPIXABA & Plataforma & Inviável \\
\hline FPSO CIDADE DE ANCHIETA & Plataforma & Inviável \\
\hline FPSO CIDADE DE NITEROI (MARLIM LESTE) & Plataforma & Inviável \\
\hline FPSO CIDADE DE RIO DAS OSTRAS & Plataforma & Inviável \\
\hline FPSO CIDADE DE VITORIA & Plataforma & Inviável \\
\hline FPSO CIDADE DO RIO DE JANEIRO & Plataforma & Inviável \\
\hline FPSO FRADE & Plataforma & Inviável \\
\hline FPSO P-50 (ALBACORA LESTE) & Plataforma & Inviável \\
\hline FPSO P-54 & Plataforma & Inviável \\
\hline FPSO P-57 & Plataforma & Inviável \\
\hline FPSO P-58 & Plataforma & Inviável \\
\hline FPSO P-62 & Plataforma & Inviável \\
\hline
\end{tabular}




\begin{tabular}{|c|c|c|}
\hline Porto & Detalhamento & Classificação \\
\hline FSO - CIDADE DE MACAE & Plataforma & Inviável \\
\hline FSO - P-38 (MARLIM SUL) & Plataforma & Inviável \\
\hline MONOBÓIA 1 PRA-1 & Monoboia & Inviável \\
\hline P-31 (ALBACORA) & Plataforma & Inviável \\
\hline P-32 (MARLIM) & Plataforma & Inviável \\
\hline P-33 (MARLIM) & Plataforma & Inviável \\
\hline P-35 (MARLIM) & Plataforma & Inviável \\
\hline P-37 (MARLIM) & Plataforma & Inviável \\
\hline P-47 (MARLIM) & Plataforma & Inviável \\
\hline P-63 FPSO PAPA-TERRA & Plataforma & Inviável \\
\hline FPSO PIONEIRO DE LIBRA & Plataforma & Inviável \\
\hline SALEMA / BIJUPIRA & Plataforma & Inviável \\
\hline RIO DE JANEIRO & Terminal & Disponível \\
\hline ANGRA DOS REIS & Terminal & Disponível \\
\hline SAO SEBASTIAO & Terminal & Disponível \\
\hline BACIA DE SANTOS (BOIA DE AMARRAÇÃO) & Monoboia & Inviável \\
\hline FPSO CIDADE DE ANGRA DOS REIS & Plataforma & Inviável \\
\hline FPSO CIDADE DE CARAGUATATUBA & Plataforma & Inviável \\
\hline FPSO CIDADE DE ILHABELA & Plataforma & Inviável \\
\hline FPSO CIDADE DE ITAGUAÍ & Plataforma & Inviável \\
\hline FPSO CIDADE DE ITAJAÍ & Plataforma & Inviável \\
\hline FPSO CIDADE DE MANGARATIBA & Plataforma & Inviável \\
\hline FPSO CIDADE DE MARICA & Plataforma & Inviável \\
\hline FPSO CIDADE DE PARATY & Plataforma & Inviável \\
\hline FPSO CIDADE DE SANTOS & Plataforma & Inviável \\
\hline FPSO CIDADE DE SÃO PAULO & Plataforma & Inviável \\
\hline FPSO CIDADE DE SÃO VICENTE & Plataforma & Inviável \\
\hline FPSO CIDADE DE SAQUAREMA & Plataforma & Inviável \\
\hline FPSO DYNAMIC PRODUCER & Plataforma & Inviável \\
\hline FPSO P-66 LULA SUL & Plataforma & Inviável \\
\hline SANTOS & Terminal & Disponível \\
\hline PARANAGUA & Terminal & Disponível \\
\hline SAO FRANCISCO DO SUL & Monoboia & Inviável \\
\hline TRAMANDAI & Monoboia & Inviável \\
\hline RIO GRANDE & Terminal & Disponível \\
\hline PORTO ALEGRE & Terminal & Potencial \\
\hline
\end{tabular}




\section{Anexo 1 - Tarifas TRANSPETRO de transporte em dutos curtos}

\section{TABELA DE TARIFAS}

Transporte Dutoviário - Dutos Curtos

\begin{tabular}{|c|c|c|c|}
\hline ORIGEM & DESTINO & PRODUTO & $\mathrm{R} \$ / \mathrm{m}^{2}$ \\
\hline SANTOS & CUEATÅO & Claros & $6,60[\mathrm{~A}]$ \\
\hline SANTOS & CUEATÅO & Escuros & $6,11[\mathrm{~A}]$ \\
\hline RPBC & CUEATÅO & Claros & $3,44[\mathrm{~A}]$ \\
\hline RPBC & CUBATÅO & Escuros & $3,67[\mathrm{~A}]$ \\
\hline RECAP & SÅO CAETANO DO SUL & Claros & $5,61[A]$ \\
\hline RECAP & SÅO CAETANO DO SUL & Escuros & $7,72[\mathrm{~A}]$ \\
\hline MADRE DE DEUS & RLAM & Claros & $4,99[\mathrm{~A}]$ \\
\hline MADRE DE DEUS & RLAM & Escuros & $4,86[A]$ \\
\hline MADRE DE DEUS & RLAM & GLP & 5,03 [A] \\
\hline RLAM & BECAN & Claros & $7,36[\mathrm{~A}]$ \\
\hline ILHA D'AGUA & REDUC & Claros & $7,86[\mathrm{~A}]$ \\
\hline ILHA D'AGUA & REDUC & Escuros & $13,46[\mathrm{~A}]$ \\
\hline REDUC & GALEAO & QAV & 6,29 [A] \\
\hline CAMPOS ELISEOS & REDUC & Claros & 3,87 [A] \\
\hline BRASILIA & CIAS. DISTRIBUIDORAS & Claros & $4,18[\mathrm{~A}]$ \\
\hline RIBEIRAO PRETO & CIAS. DISTRIBUIDORAS & Claros & $5,65[\mathrm{~A}]$ \\
\hline SÅO CAETANO DO SUL & CIAS. DISTRIBUIDORAS & Claros & $5,19[\mathrm{~A}]$ \\
\hline SÅO CAETANO DO SUL & BRASKEM & Claros & $4,06[A]$ \\
\hline BARUERI & CIAS. DISTRIBUIDORAS & Claros & $3,44[\mathrm{~A}]$ \\
\hline GUARULHOS & CUMBICA & QAV & $5,19[\mathrm{~A}]$ \\
\hline GUARULHOS & MERCOIL & Claros & $4,03[A]$ \\
\hline GUARULHOS & BR & Claros & $4,03[\mathrm{~A}]$ \\
\hline GUARULHOS & REPSOL-YPF/COPAPE & Claros & $4,03[A]$ \\
\hline ALEMOA & LIQUIGAS & GLP & $3,87[\mathrm{~A}]$ \\
\hline ALEMOA & ULTRAGAS & GLP & $3,87[\mathrm{~A}]$ \\
\hline
\end{tabular}

Fonte: Transpetro (2018). 